\title{
ADEQUATE BIM LEVEL OF DETAIL FOR LCA ENERGY SIMULATION
}

Philip Penn A thesis submitted to Victoria University of Wellington in fulfilment of the requirements
for the degree of Master of Building Science

Victoria University of Wellington

October 2018 


\section{Abstract}

This research tested the new LCAQuick Residential, a computer-based analysis tool developed by BRANZ (available from www.branz.co.nz). This tool is designed to allow the ready preparation of a LCA at an early point in the design process for a residential house. The research problem was created by the infancy of the program and its unknown ability to produce results to support decision making to include Life Cycle Analysis (LCA) for designers and developers seeking a more sustainable design outcome.

The method of testing was to take a real house design and model it using Autodesk Revit ${ }^{\mathrm{TM}}$ to create a virtual model. The virtual model was then used to input material quantities into LCAQuick Residential, which in turn generated a full set of Life-Cycle Energy (LCE) data. To test this approach, the data from a Quantity Surveyor (Schedule of Quantities) was also used as input to LCAQuick Residential, and the results compared. For this research on the energy component of LCA was examined - the LCE.

It was found that the material quantities generated by each of the approaches differed, and it was necessary to critically compare them to ensure material volumes, density and quantity were appropriately matched and entered into the tool. Considerable care was also required to ensure materials were correctly identified and allocated to the appropriate LCAQuick library material. 


\section{Acknowledgements}

Over the course of this research, I had gone though many ordeals that tested both my mind and my will to endure. I was faced with failure and difficulties in every attempt I took at tackling this research. My initiative at the time was driven by my father's island saying "He who runs alone, runs the farthest" which was his way of teaching his children to go through life strong and independent.. I found out the hard way that this was not true for if it were not for the following people, I would have not come so far.

\section{To the Staff of Victoria University of Wellington}

First and foremost, I would like to thank my Supervisor Nigel Isaac's to whom I owe a great amount gratitude and respect. You changed the way that I saw myself and the world around me. I found myself more confident to ask questions and engage in conversations, which was more than I usually would do before. It took a lot of patience on your behalf to get me to where I am now to which am truly thankful for. Were it not for you, I would not have thought any of this possible. Thank you Nigel.

The Honourable Luamanuvao Winnie Laban, you were the Samoan element that pulled me back to the mark. I had lost my way in the Palagi world and was ready to give up before you entered the picture. Since then, you have open doors for me and guided me in the Fa'aSamoa way to preserve the hardships that I had left to go. Fa'afetai mo lou alofa.

David Hakaria, you have known me since my first year and was responsible for giving me my first shot at the real world. You have seen fail many times since then but you were always there when I asked for help. Whakawhetai Koe Hux, The Man.

\section{To Building Research Association of New Zealand (BRANZ) Staff:}

Brian Berg, for understanding of what it is like to be struggling student. You went the extra mile for me knowing full well that you did not have to. That is a kindness from you that I am grateful for, as you are a true legend.

Casamir MacGregor, for providing me reference documents and "don't give up on you masters, Philip" quote once every few months. Thank you.

Ann Duncan, for your laptop that allowed me to do work during crunch times. Thank you.

David Dowell, thank you for your help and your patience with me as I tried to keep up as best I could

John Burgees, for without your data none of research would be possible. Thank you.

\section{To the Scholarship Awards I received:}

Thank you to the Sanitarium Pasifika Scholarship award for funding me in early months of the research.

Thank you to the BRANZ postgraduate scholarship award for the financial support got me though the final months of my research. 


\section{To my Friends}

To Rokini Seruvakula, for being that one friend who walks in when whole world walks out - a true friend. I would like to acknowledge your family as well, Bill, Loata, Ben, Alice, and little Rejieli for taking me in when I had nowhere else to go. Especially to your Mother, Loata for sticking up with me long after I had overstayed my welcome. Vinaka Vinaka vaka levu.

And finally, to the Auckland Family: Portesano Taavao, Gloria Taavao, Jathan Taavao, Daniel Wiel and Ben Tupolo, for being there when a brother needed a good laugh, good company and some dank memes. Cheers guys. 


\section{Contents}

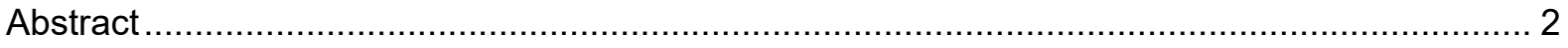

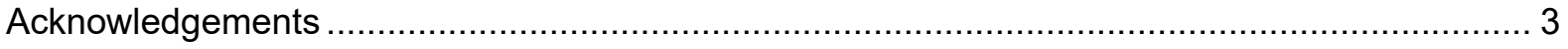

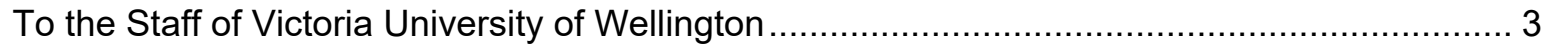

To Building Research Association of New Zealand (BRANZ) Staff: ...................................... 3

To the Scholarship Awards I received: ......................................................................... 3

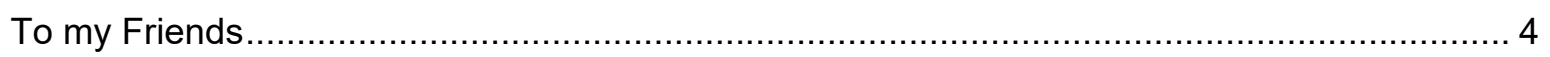

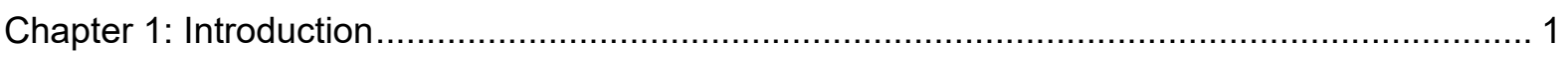

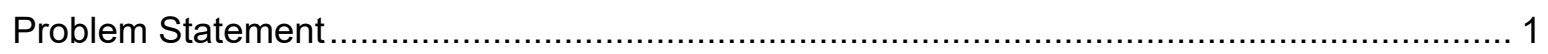

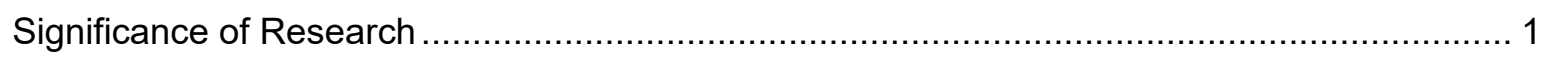

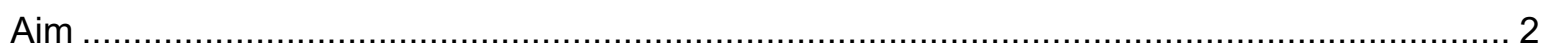

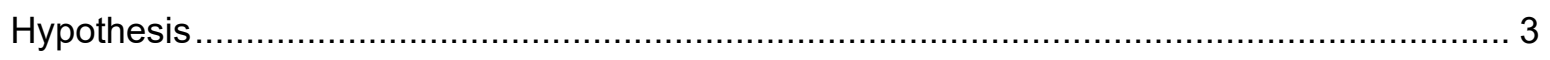

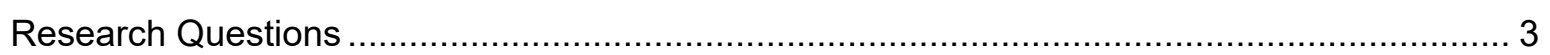

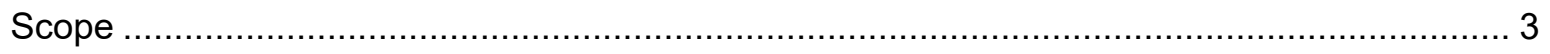

Thesis Outline

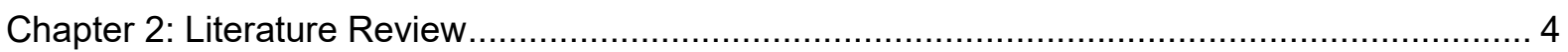

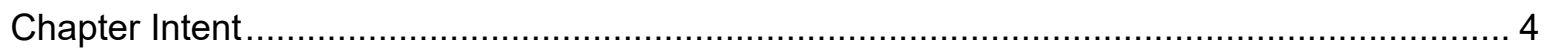

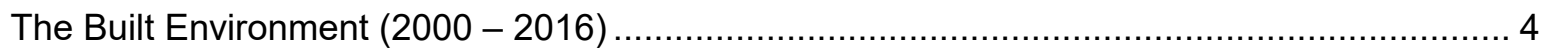

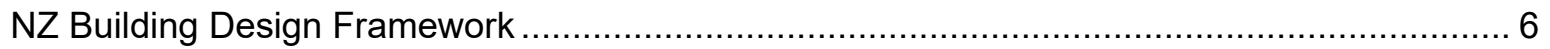

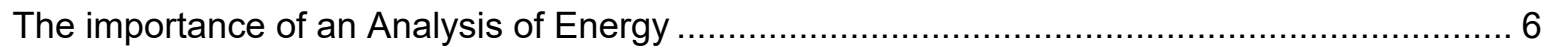

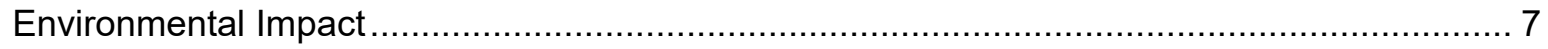

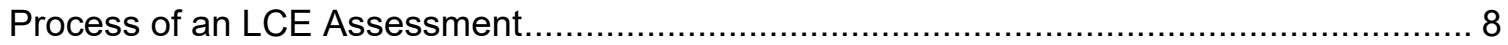

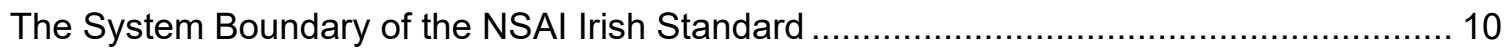

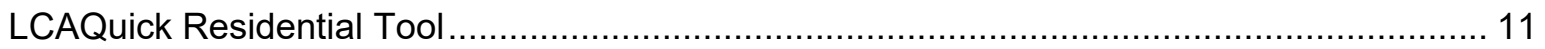

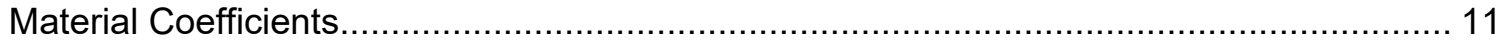

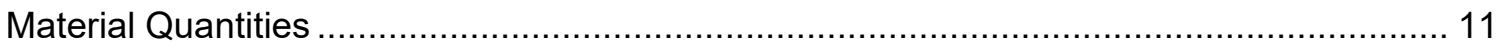

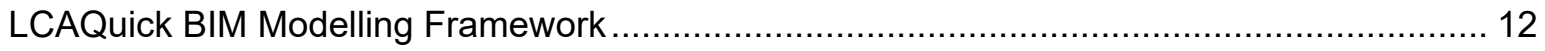

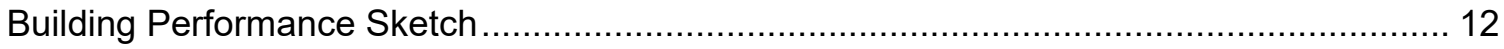

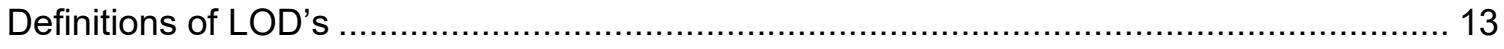

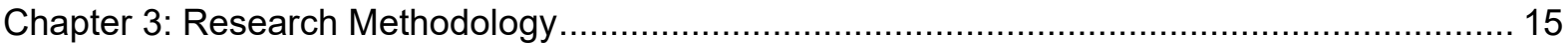

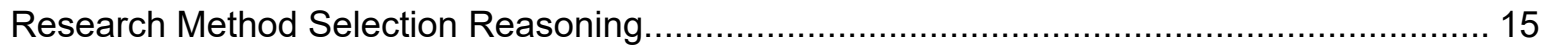

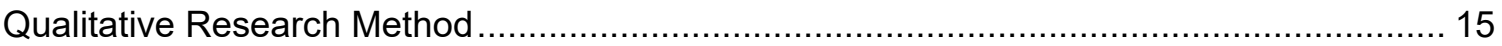

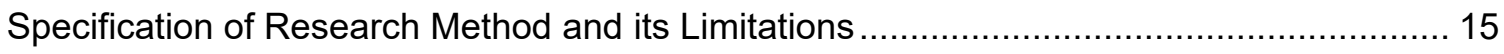

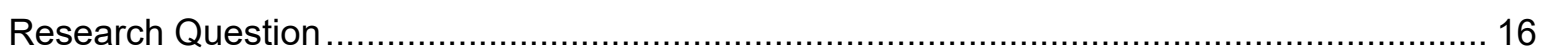

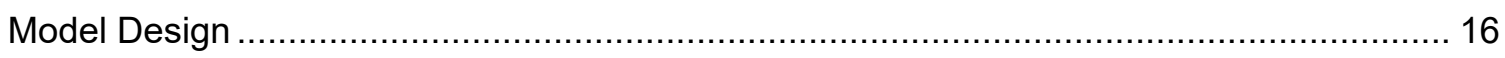


Simulation Methods

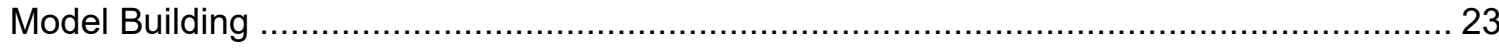

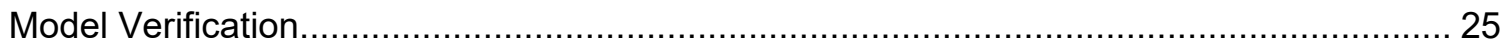

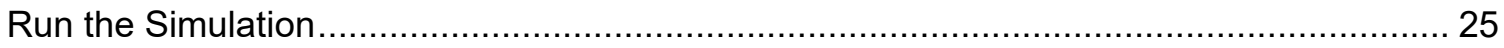

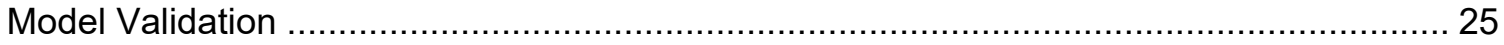

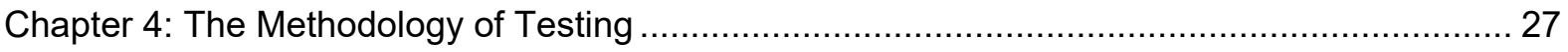

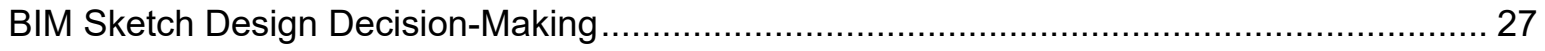

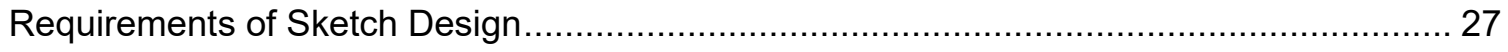

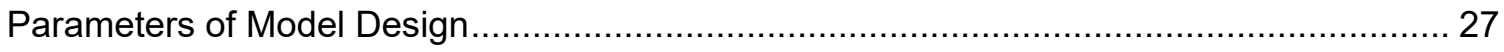

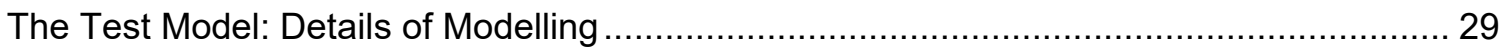

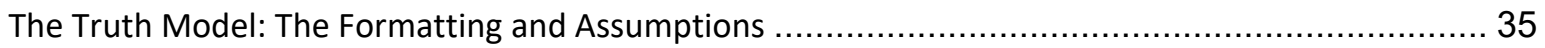

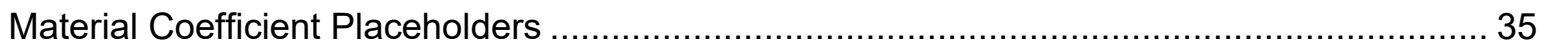

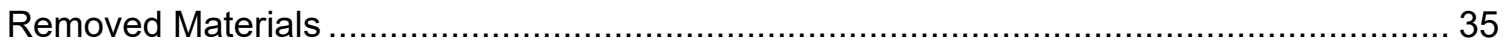

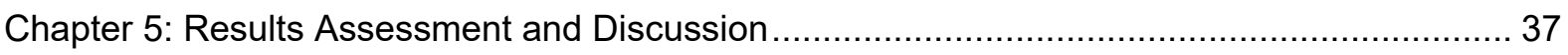

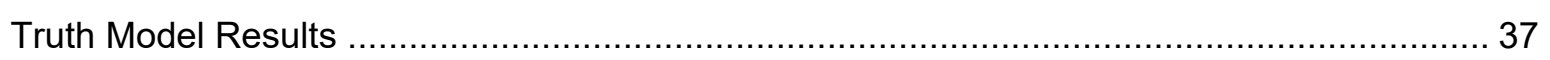

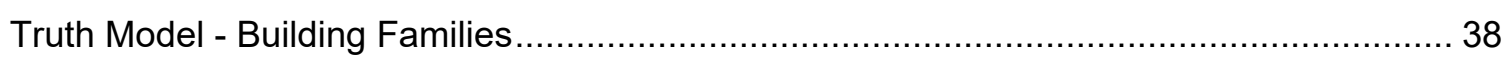

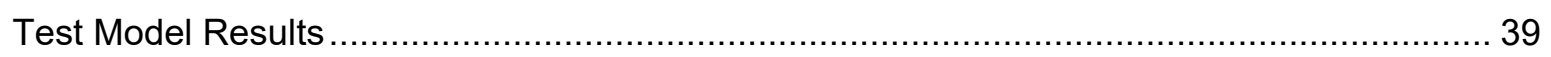

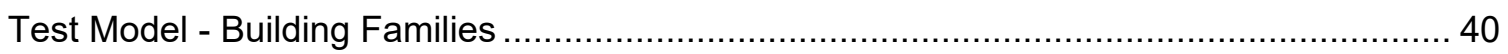

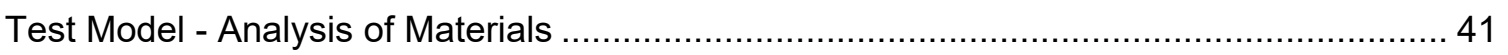

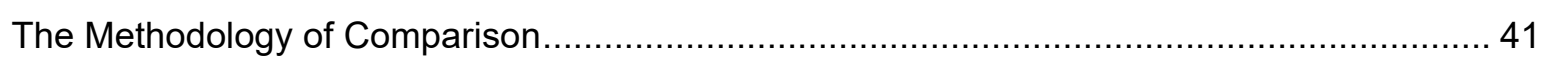

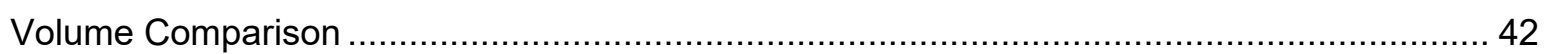

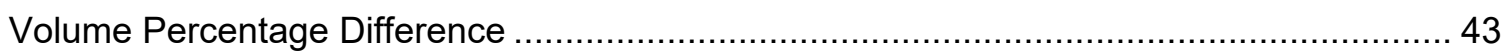

The Total Primary Energy Comparison: Truth Model vs Test Model: .................................... 47

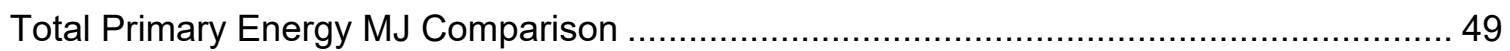

Percentage Difference: Truth Mode vs Test Model .......................................................... 50

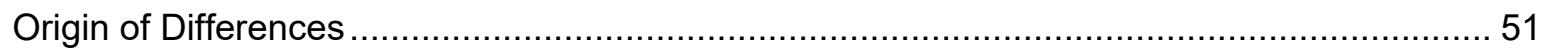

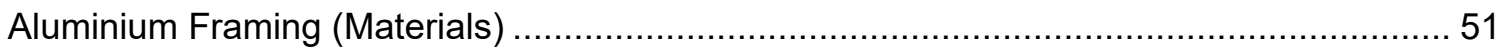

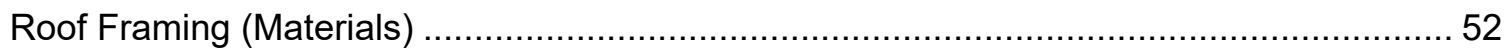

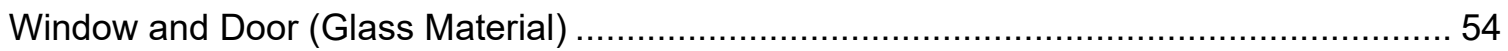

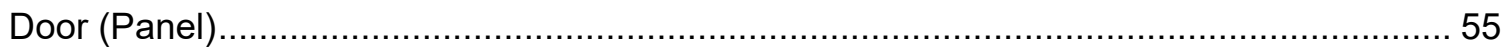

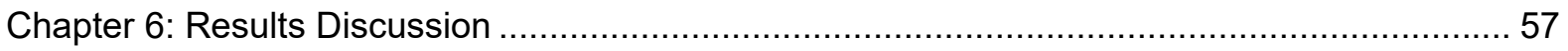

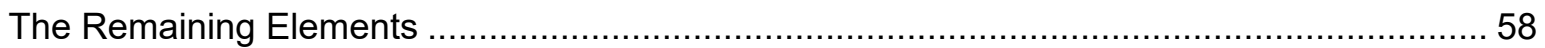

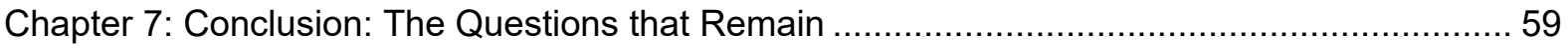

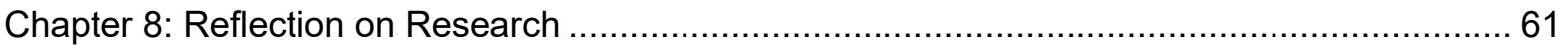

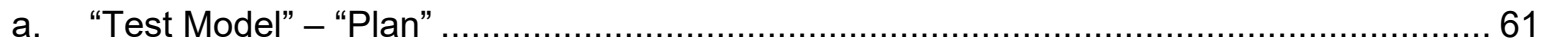

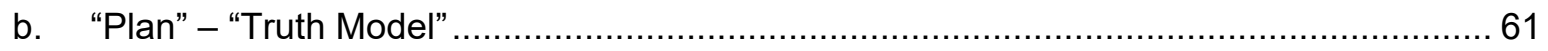


Consequence of a lack of Plan to Truth Model relationship. 62

References 65

Appendix 1: Truth Model Schedule Sheet... 67

Appendix 2: The Truth Model Placeholders 73

Appendix 3: Test Model Schedule Sheet ..... 75

Appendix 4: The Unmatched Results of the Test Model 79 


\section{Chapter 1: Introduction}

As population continues to grow, so too does the demand for housing, especially in rural areas (Bastone \& Reeve, 2014). However, with this growth in demand comes the need for more resources The individual resource demand has a limited effect on the environment, but the needs of a full house multiply these demands. Thus, a drive for a more sustainable housing development has become a major worldwide initiative (Architecture 2030, 2002).

Some of these initiatives have given way to new technologies and building techniques that increase the energy efficiency of a home. In the New Zealand context, the New Zealand Building Code that sets out requirements for new buildings, other energy efficiency standards generally address the "use phase" of a building. Though this would address a majority of the housing stock of the country that is currently in its "use phase", future housing development needs to consider both the environmental impact from the "planning stage" through its lifetime operation, ultimately reducing the environmental effort needed to maintain the house in years to come.

\section{Problem Statement}

If the environmental impact of new housing is to be quantified, it will be necessary to have suitable analysis tools. Although such tools exist now, they require large amounts of fine detailed data that is commonly not available to be used at the most critical stage - the building design.

According to the Royal Society of New Zealand (RSNZ), the majority of buildings that will exist in New Zealand by 2050 have already been built (Sims, et al., 2016). Although a move forward in improving the energy performance would require retrofitting these already existing houses, the constraint on most of these improvements are limited by the original house design. Furthermore, the research suggests that though technological improvements are important, education and training for those designing, manufacturing, installing and using buildings are also key to reducing Green House Gas emissions over the lifetime of the building (Sims, et al., 2016). There is a need to consider the ongoing environmental impact of design decisions but how can these help inform the early stages of decision-making?

Life Cycle Assessment ( $L C A)$ is a process that calculates the environmental impact of a building. When used in the design process, LCA can inform designers of environmental consequences of their decisions prior to final decisions made at key intervals throughout a building development stages. This is discussed in further detail around Table 2

There are many tools that exist to help designers to perform a building LCA, however, according to Berg's thesis, the current calculation of "building material" for LCA is too complex, causing poor and ineffective integration into building designer's sketch design processes, practices, and decisions (Berg, 2014). This hinders the adoption of LCA at early stages of a project where its ability to provide valuable insight on positive environmental decision-making is neglected, due to complexity of use.

\section{Significance of Research}

According to a LCA case study on residential housing by David Drysdale and Barbara Nebel, the largest environmental impact results from the operation of the house over its life rather than its initial construction stages and manufacturing process (Collins, Blackmore, Drysdale, \& Barbara, 2010). The operational LCA impact can be best addressed through decision-making at the design stages of a project. 
However, to make a good decision, the decision maker must be informed on the consequences and outcomes of their decisions. Simulations allow for mathematical predictions and designer assumptions to be tested beforehand in order to justify the best course of action. This simulation may be time consuming and arduous in production, and may not seem appropriate for most designers in time-strict projects.

Thus, this research aims to contribute to the alleviation of the existing issue of "time-consuming modelling." The testing carried out by this research aims to establish how much detail is required to achieve both time saving for modelling and error minimisation for the LCA.

The expected outcome of this research is an understanding of a reliable method of BIM modelling able to produce acceptable LCAQuick results. Fundamentally, it is the understanding of what is the "reasonable" level of development and/or detail required of BIM models.

Following Berg's approach to addressing the issue of material quantity calculation complexity (Berg, 2014), this research explores the use of an LCAQuick tool that integrates the use of threedimension computer based models, commonly referred to as Building Information Models (BIM). The BIM will be built using the Computer Aided Design (CAD) tool REVIT'TM1. The LCAQuick analysis will be undertaken using the BRANZ developed tool LCAQuick. This tool was developed by BRANZ and is currently publically available for office buildings ${ }^{2}$. A pre-release version of LCAQuick for housing provided to be used for this research.

BIM has the potential to calculate and transfer data on material quantity into an LCAQuick tool. The question still remains as to how to simplify the building material calculation complexity for LCAQuick, specifically due to the nature of a BIM model. BIM is capable of capturing vast amounts of information about a building design, but this still leaves the time-consuming process of asking "how much necessary information" needs to be used by the model.

How much detail is too much? How much detail is too little? This research looks for a middle ground which makes use of the BIM design process, but transfers as little data as possible in order to provide an adequate level for the LCAQuick. The long-term goal is to enable LCAQuick to be integrated within project development stages through BIM.

For the purpose of this research, it has been decided that a variation within $\pm 10 \%$ in the final LCA will be an acceptable error when comparing the use of the BIM Revit model with the Quantity Surveyor's schedule of quantities. Furthermore, this research does not deal with the operating or embodied energy specifically but rather the Life-Cycle Energy (LCE).

Therefore, this research deals only with the embodied energy component of the LCA calculation. It does not consider the operating energy - which would be required for a full LCA.

Aim

The aim of this research is to determine what "Level of Detail" produced by a BIM model gives adequate results for a Life-Cycle Analysis. The BRANZ developed software tool "LCAQuick Residential" will be used to calculate the LCE.

\footnotetext{
1 https://www.autodesk.com/products/Revit ${ }^{\mathrm{TM}}$-family/overview

2 https://www.branz.co.nz/cms display.php?sn=308\&st=1\&pg $=17752$
} 


\section{Hypothesis}

It is hypothesized that a New Zealand residential house BIM model plan can produce a material quantity list reliable enough for LCAQuick calculations.

\section{Research Questions}

Primary question:

- Can a REVITTM BIM model produce consistent, reliable results for an LCE calculation?

Secondary questions:

- Is REVITTM a suitable tool for this work, and what (if any) special care needs to be taken?

- Is LCAQuick a suitable tool for this work, and what (if any) changes are required

- How accurate is enough for informed decision-making about building material LCAQuick simulation results?

- Is the information needed available in the early phases of the design process, and to the level of detail required to produce accurate results?

\section{Scope}

This research will use the LCA tool (LCAQuick) under development at BRANZ for residential housing. This research is constrained by the fact that there are a limited number of New Zealand based material LCE coefficients, but no attempt has been made to develop new or more accurate coefficients. The research does not investigate the process of creating an LCE, but uses the standard methodology embodied in the LCAQuick tool.

\section{Thesis Outline}

Chapter 2 provides a literature review. It explores the New Zealand context and need for LCA, the LCA framework and the development of the LCAQuick tool. It investigates the methods used in BIM in order to generate the required inputs for LCA.

Chapter 3 sets out the research methodology, explaining the creation of the Quantity Surveyor and the REVIT TM model take-off quantity schedules

Chapter 4 describes the development of the two house models - the "Truth Model" created using the Quantity Surveyor schedule and the "Test Model" using the REVIT TM developed schedule.

Chapter 5 gives the results from the two different schedules when used in LCAQuick. It examines the issues identified in the use of the LCAQuick tool and recommendations for future use. It explores in details the differences between the two house models.

Chapter 6 discusses the research results

Chapter 7 provides a conclusion and recommendations for future activity.

Chapter 8 evaluates the entirety of the Thesis and highlights areas for future research to consider.

The Appendix provides the detailed outputs for the two models. 


\section{Chapter 2: Literature Review}

\section{Chapter Intent}

The purpose of this chapter is provide context and background of the themes discussed in this research.

The literature will explain the themes of LCAQuick Residential tool and BIM modelling. As this would be the chisel to the hammer, the hammer - LCAQuick Residential tool - is accumulation of a Life Cycle Assessment which would require an understanding of how its operates, its origin and its usefulness overall. The chisel - Autodesk Revit ${ }^{\mathrm{TM}}$ - is a significant means for the LCAQuick to collect volumetric data and thus and understand of this subject must be delved into as well.

The Built Environment (2000 - 2016)

The New Zealand household consumes energy for warming and cooling, lighting and cooking. Figure 1 shows that from 1995 to 2007 the energy use in the residential sector has been steadily increasing (Ministry for the Environment). This is due to the nature of population-growth inciting more demand of energy consumption. This highlights the point that household consumption patterns can affect overall issues of sustainable development.

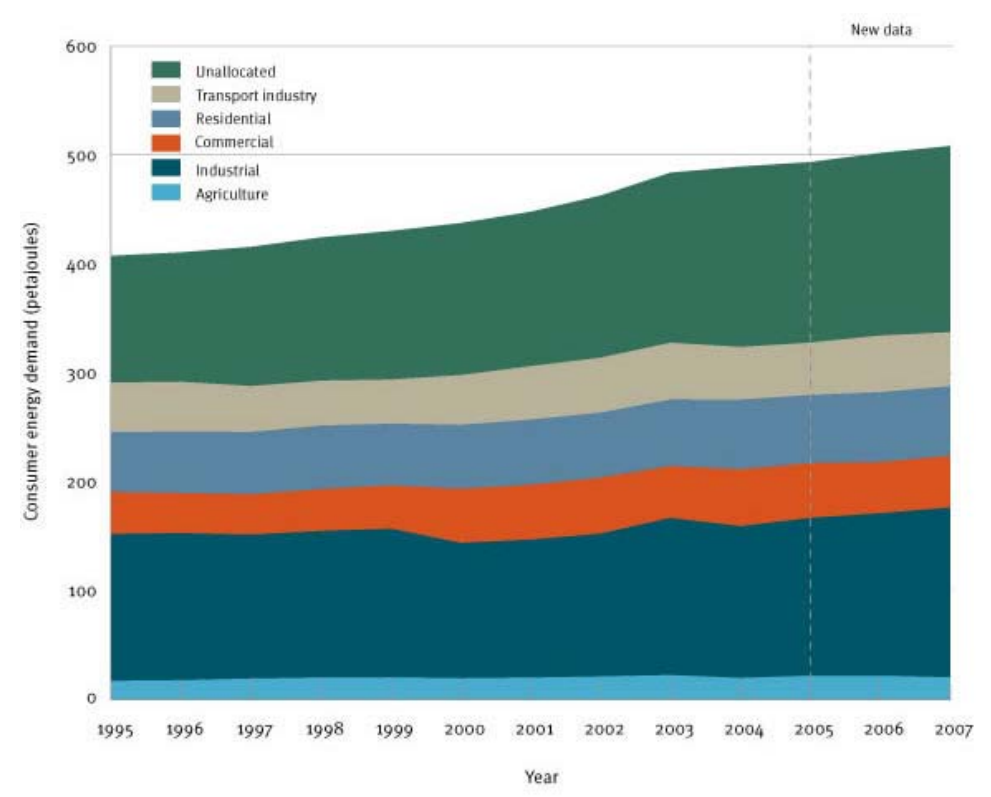

Figure 1: TOtAL CONSUMER ENERGY DEMAND IN NEW ZEALAND BY SECTOR, 1995-2007. SouRCE: (MINISTRY FOR THE ENVIRONMENT, 2009, P. PAGE 6) 


\section{Buildings}

\section{Commercial buildings}

Zero emissions by medium to long term
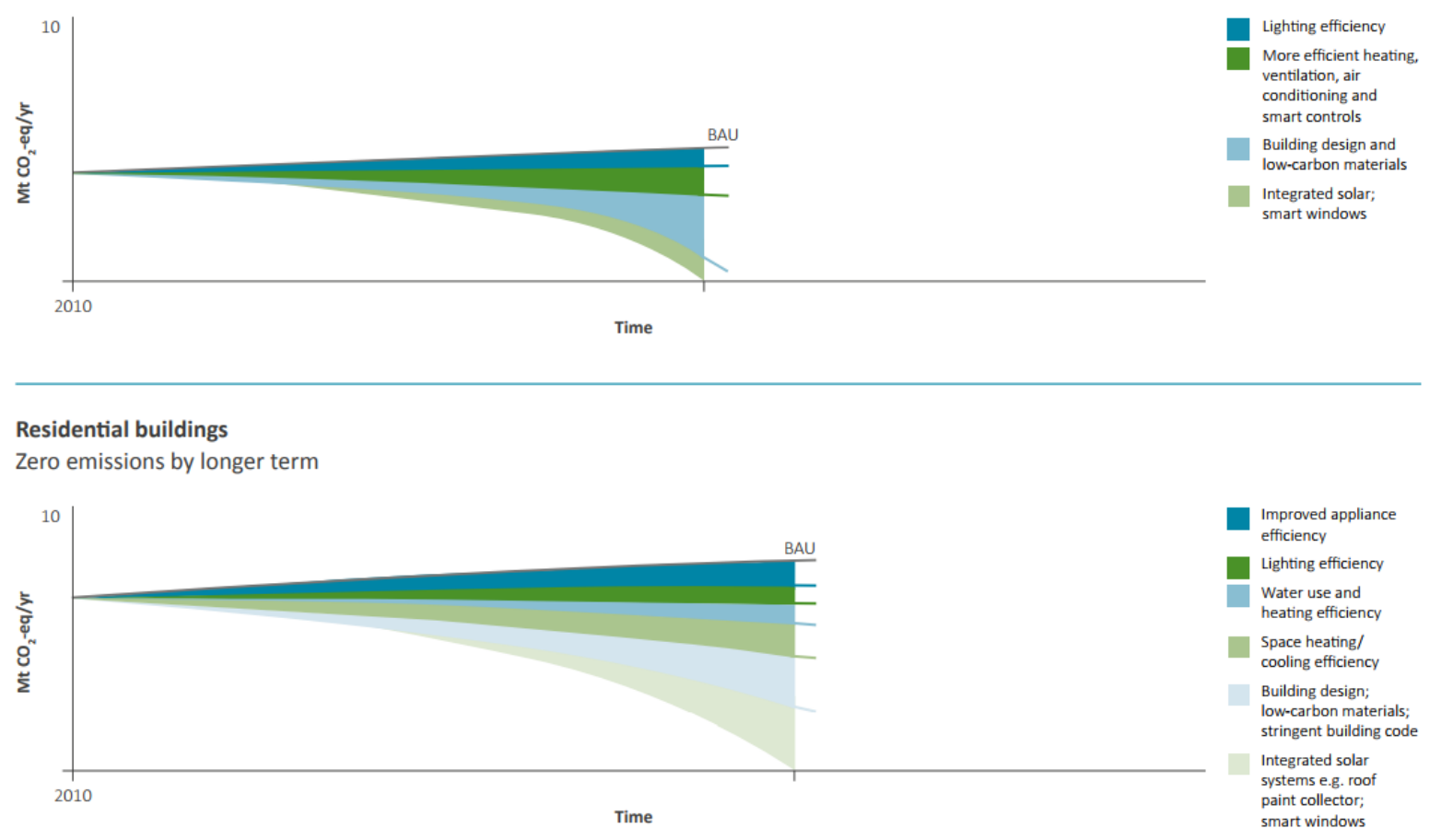

Figure 2: The New Zealand Building Stock - Commercial Versus Residential. The RESIDENTIAL DELIVERS MORE EMISSIONS OVER TIME AS COMPARED TO COMMERCIAL. SOURCE: (SIMS, ET AL., 2016, P. PAGE 17)

The RSNZ report examining issues of climate change for New Zealand included an examination of the housing stock. It found that the building sector is indirectly responsible for around $20 \%$ of New Zealand's energy related GHG emissions (Sims, et al., 2016). The greatest contributors to these energy consumption factors within the households are the consumption of fossil fuels for heating and cooking along with the thermal share for electricity generation used by appliances for heating, ventilation and cooking. As discussed earlier, this report also states that as the majority of buildings that will exist in 2050 have already been constructed, a drive towards a sustainable housing stock is vital.

One proposed initiative is the idea of sustainable house design and informed decision making during planning stages of construction. This will serve to drive new buildings to have a lower energy demand and in turn reduce the total future energy demand for heating, cooling and appliances. Incorporating timber construction materials that store carbon over the medium-tolong term may also have a positive life cycle impact (Sims, et al., 2016).

This dictates a sustainable building envelope and establishes a means of household energy and resource management that can reduce the level of environmental impact in the long run of a household/ house design. To do so one must understand context of a New Zealand household and its design framework in a New Zealand construction context to establish a means of planning. 


\section{NZ Building Design Framework}

To inform a sustainable method of planning within the NZ Building Design, one must first understand the layout of design process and key areas where important milestones dictate the outcome of the construction. Table 1 is an illustration of the traditional design framework commonly used by the NZ construction industry (NZ Construction Industry Council, 2016). The initial stages of the project highlight the gathering of all parties involved into the concept design that will later be refined through later stages. The activities up until the "Procurement Stage" allow the construction stages of the project to begin.

TABle 1: Traditional Building Design Processes Framework

\begin{tabular}{|c|l|l|}
\hline No. & \multicolumn{1}{|c|}{ Design Stage } & \multicolumn{1}{c|}{ Definitions } \\
\hline 1 & Project Establishment & $\begin{array}{l}\text { Defining the General Criteria of the project such as identifying the Client, } \\
\text { establishing the project goals and project scope. }\end{array}$ \\
\hline 2 & $\begin{array}{l}\text { The Building Performance } \\
\text { Sketch }\end{array}$ & $\begin{array}{l}\text { The development, and testing, of different building design iterations } \\
\text { comprising of different building solutions for solving design problems and } \\
\text { achieving project performance goals. The end-product of this stage is a } \\
\text { Concept Design }\end{array}$ \\
\hline \multicolumn{2}{|c|}{ Crucial Planning Stage - key players define Project Goals and Performance Goals } \\
\hline 4 & Concept Design & $\begin{array}{l}\text { At this stage, the Concept developed is a response by the design teams to the } \\
\text { project brief. Outlining specifications and procurement options are then } \\
\text { defined at this stage to further develop the concept into the next stage }\end{array}$ \\
\hline 5 & Developed Design & $\begin{array}{l}\text { The selected concept design is developed so each component, not just key } \\
\text { elements clearly defined. Typically, sketch details are produced. }\end{array}$ \\
\hline 6 & Detailed Design & $\begin{array}{l}\text { Building documentation such as plans, and specifications are produced for all } \\
\text { building elements to a level that they can directly be 'built' from. }\end{array}$ \\
\hline 7 & Procurement & \multicolumn{2}{l}{} \\
\hline
\end{tabular}

Note that in Table 1 that between the stages of "Project Establishment" and "The Building Performance sketch" is a "Crucial Planning Stage". It is by this point that the key players who are responsible for setting the Project Goals and Performance Goals for the project have been put in place. Once this has happened, the remaining process is largely fixed - therefore if there is to be an improved environmental result, it is necessary to make changes by this stage. The conventional LCAQuick cannot be undertaken by this stage due to a lack of detailed design information and construction data.

\section{The importance of an Analysis of Energy}

Humans have historically had energy-conscious designs when constructing their homes. Thus, to endure unwelcoming environmental conditions, homes were designed to optimize an envelope of habitable settings, ensuring survivability. A perfect example of this would be the Inuit styled Igloos. An Igloo is a snow block built dome that insulates its occupant from extreme winds and cold, designed specifically for cold climates. Research by Kershaw .et al explored the characteristics of traditional-style Inuit snow houses, which he later refers to as "Iglus" (G. , Scott, \& Welch, 1996).

The research investigated two structures, designed to simulate (large iglu) occupation for extended periods of time i.e. seasonal base, and (Small Iglu) occupation for short periods i.e. hunting expeditions. 

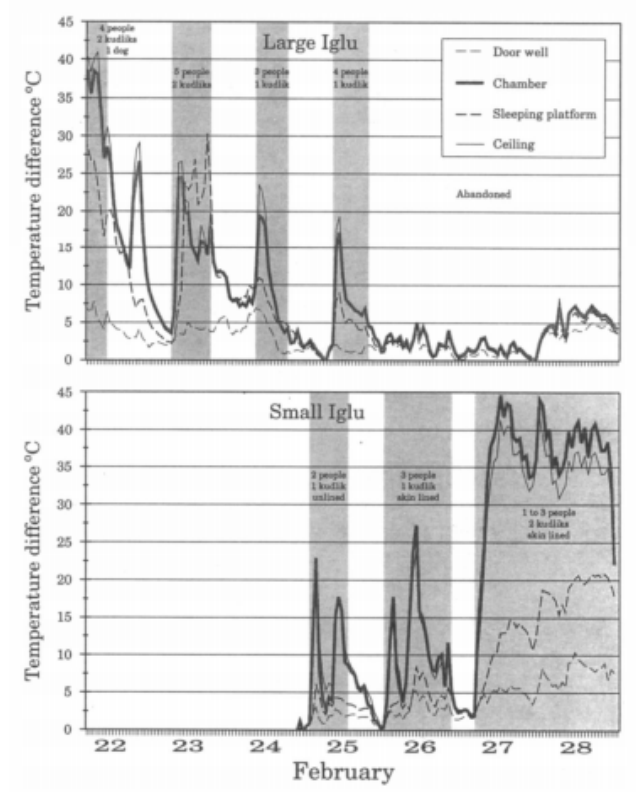

FIGURE 3: THE DAILY VARIATION OF TEMPERATURE FOR A LARGE AND SMALL IGLU AT SLEEPING PLATFORM LEVEL. ONLY THE DOOR WELL WAS SEALED OFF ISOLATING OCCUPANTS WITHIN THE

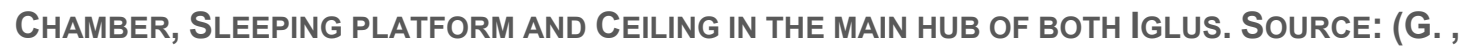
SCOTT, \& WELCH, 1996, P. PAGE 334)

Figure 3 shows is the ability of an Iglu to capture and retain heat while also taking into account the "activity/ role" that the Iglu was designed for. It is important to note that the interior walls of the Iglu chamber are lined with animal skins that serve as insulation to capture the heat. Overall, in cold climates, the iglu design has kept Inuit people alive for years in harsh conditions. This is due to efficiency of energy it takes to design and operate an iglu over the course of its life. This is why energy efficiency is a vital component when designing for human occupancy.

Fast-forward to the modern day, a human home has evolved to meet their ever-developing demands for comfort. When it comes to the procurement, maintenance and deconstruction of an Igu, the materials are readily available from the remote environment - with the exception of insulation - animal hide that may require more time and effort to prepare. However, unlike an Iglu, modern houses cannot simply just discard their materials to "melt" back into the environment. Furthermore, materials do not just "snow" readily for construction. There are more requirements and consequences for materials that are used in modern day home construction. In the case of this research, this involves the energy embodied within the construction materials.

\section{Environmental Impact}

An environmental impact is a change and the associated consequences to the environment, caused by the direct activities of the development and production of a product or service (Sidroff, 2004). The environmental impact can be measured by the indicators produced as part of an environmental framework (Alcorn, 2010). This is where tools with environmental frameworks, such as LCAQuick, provide a systematic method, for measuring and describing the environmental impact caused by the manufacturing, construction, operation, and demolition activities throughout the life cycle of building. Society can establish a maximum (or minimum) 
environmental impact, such as defining the levels of thermal performance required in housing under NZBC Clause H1 Energy Efficiency. LCA Framework

LCA quantifies use of resources and energy and emissions to land, water and air that arise across the life of any product (Berg, 2014). A product may be as small as a nail or as large a building, a service or even an organisation. The scope of analysis for an LCE begins at the point that resources are extracted from the earth (including exploration, land clearance and/ or removal of overburden that may precede extraction) and finishes when emissions return to the environment.

\section{Process of an LCE Assessment}

The following are the four main stages of an LCE assessment methodology (Table 2) which defines what is tested and what is not. These are the definition of goal and scope, analysis of inventory, assessment of impact and interpretation of the results. The general definition of what each stages covers sets the scope of how this research will conduct its LCE analysis for later stage of testing in Chapter 4 of this research.

\section{TABLe 2: The overall LCE Assessment Methodology}

\begin{tabular}{|c|c|}
\hline $\begin{array}{l}\text { Stage 1: Goal and Scope } \\
\text { definition }\end{array}$ & $\begin{array}{l}\text { During this first stage, the aims of the LCE study are } \\
\text { documented. This helps to define what is included and what is } \\
\text { excluded (for the system boundary see Figure } 4 \text { ). }\end{array}$ \\
\hline $\begin{array}{l}\text { Stage 2: Inventory } \\
\text { Analysis }\end{array}$ & $\begin{array}{l}\text { This is the stage when data is collected for processes within the } \\
\text { system boundary. For example, for a manufacturing operation } \\
\text { making product A, this would typically include the following } \\
\text { inputs: } \\
\text { 1. Energy used } \\
\text { 2. Materials Used } \\
\text { 3. Water Use }\end{array}$ \\
\hline $\begin{array}{l}\text { Stage 3: Impact } \\
\text { assessment }\end{array}$ & $\begin{array}{l}\text { This provides an understanding of how LCE flows contribute to } \\
\text { environmental impacts. }\end{array}$ \\
\hline Stage 4: Interpretation & $\begin{array}{l}\text { The fourth stage of LCE - interpretation - is where conclusions } \\
\text { are drawn from the study findings, bearing in mind the goal and } \\
\text { scope, the quality of data used and any assumptions that have } \\
\text { been made. Sensitivity analysis is useful for testing significance } \\
\text { of uncertainties in the study and how these may effect } \\
\text { conclusions. }\end{array}$ \\
\hline
\end{tabular}

Though Table 2 covers the general scope of how a LCE justifies its analysis, a more detail component needs to be explained further. This is the System boundary where the overall Life Cycle analysis of a building material is classified for levels of its emissions. The System Boundary is framework of analysis that occurs in the Stage 2 and Stage 3 of the LCE assessment methodology.

The System boundary determines the processes that are taken into account for the object of assessment (NSAI Standards: Irish Standard I.S. EN 15978, 2011). As described by the standard, a new building can utilize the system boundary from the building life cycle as shown in Figure 4, which is stages A to $\mathrm{C}$. However, for an existing building, the system boundary includes all stages that represent the remaining service life, and the end of life stage of the building.

The setting of the system boundaries follows the "modularity principle": Where processes influence the building's environmental performance during its life cycle, they shall be assigned to 
the module in the life cycle where they occur. For a majority of materials tested this usually means that they will undergo the Stages of A1-3, A4-5, B2-B4, C1-C4 and D which is the general analysis criteria set for the LCAQuick Residential Tool as well as the main outputs. 
The System Boundary of the NSAI Irish Standard

BUILDING ASSESSMENT INFORMATION

\begin{tabular}{|c|c|c|c|c|c|c|c|c|c|c|c|c|c|c|}
\hline \multicolumn{14}{|c|}{ BUILING LIFE CYCLE INFORMATION } & \multirow{2}{*}{$\begin{array}{l}\begin{array}{l}\text { SUPPLEMENTARY INFORMATION } \\
\text { BEYOND THE BUILDING LIFE CYCLE }\end{array} \\
\begin{array}{c}\text { D } \\
\end{array}\end{array}$} \\
\hline \multicolumn{3}{|c|}{ A1-3 } & \multicolumn{2}{|r|}{ A4-5 } & \multicolumn{5}{|c|}{ B1-7 } & \multicolumn{4}{|c|}{ C1-4 } & \\
\hline \multicolumn{3}{|c|}{ PRODUCT Stage } & \multicolumn{2}{|c|}{ CONSTRUCTION PROCESS stage } & \multicolumn{5}{|c|}{ USE STAGE } & \multicolumn{4}{|c|}{ END OF LIFE stage } & \multirow{2}{*}{$\begin{array}{l}\text { Benefits and loads beyond the } \\
\text { system boundary }\end{array}$} \\
\hline $\mathrm{A1}$ & A2 & A3 & $\mathrm{A} 4$ & A5 & B1 & B2 & B3 & B4 & B5 & $\mathrm{C} 1$ & $\mathrm{C} 2$ & $\mathrm{c3}$ & C4 & \\
\hline $\begin{array}{l}\text { Raw } \\
\text { Material } \\
\text { Supply }\end{array}$ & Transport & Manufacturing & Transport & \begin{tabular}{|l|} 
Construction- \\
Installation process
\end{tabular} & Use & Maintenance & Repair & Replacement & Refurbishment & \begin{tabular}{|l} 
De-construction \\
demolition
\end{tabular} & Transport & \begin{tabular}{|l|} 
Waste \\
processing
\end{tabular} & Disposal & $\begin{array}{l}\text { Reuse- } \\
\text { Recover- } \\
\text { Recycling- } \\
\text { potential }\end{array}$ \\
\hline & & & scenario & scenario & \begin{tabular}{|l|} 
scenario \\
B6 Opera \\
scenario \\
B7 Opera \\
scenario \\
\end{tabular} & $\begin{array}{l}\text { scenario } \\
\text { gy use } \\
\text { er use } \\
\end{array}$ & scenario & scenario & scenario & scenario & scenario & scenario & scenario & \\
\hline
\end{tabular}

FIGURE 4: AN EXAMPLE OF A LIFE CYCLE ASSESSMENT. SOURCE: (NSAI STANDARDS: IRISH STANDARD I.S. EN 15978, 2011)

$10 \mid \mathrm{Page}$ 


\section{LCAQuick Residential Tool}

The LCAQuick Residential tool employs a LCE framework analysis that can be used influence building design decisions at any stage of construction or operation - from early stages of planning to performance in use. In practice, the process of LCE normally consist of a LCE practitioner accumulating LCAQuick material coefficients along with a Quantity Surveyor supplying a schedule of material quantities. These variables come together for the calculation results that can be used to justify design choices from the conception phase through to construction. The justifying factor is the influence brought by the "Environmental Impact" that is established by the wider society and in the specific building case calculated by the LCAQuick Residential calculation method.

\section{"Quantities of Materials $\times$ Material Environmental Coefficients = Environmental Impact"}

The formulae above describes that the "quantities of materials" of a specified design is multiplied by a relative "material environmental coefficients", stored in LCAQuick material library, would result in the "Environmental Impact" of that particular design. Based on this there are three important factors in LCAQuick calculation: (1) "material coefficients", (2) "material quantities", and (3) "environmental impact". It is therefore important to clarify their definitions to establish the context of how they are to be used in later chapters

\section{Material Coefficients}

Understanding the energy embodied in a material raises awareness as to the contribution such a material has to a building construction composition - in turn- its affects the building energy efficiency which can lead to reduced maintenance and procurement costs. This is vital avenue for business looking to pursue quality over quantity design.

The accepted definition this research uses is:

The embodied energy of a product is the sum total of all energy incorporated or invested, throughout the various stages of manufacture, from raw material to finished product. - (G. , Scott, \& Welch, 1996)

This is measured by a materials energy coefficient, which is the energy required to produce a unit of the material - the energy per unit mass or per unit volume.

The material coefficients are based on information that is mostly readily available from manufacturers on the emissions of their products. In cases where this information is not readily available, data on some materials are also collected in the BRANZ research library. Where New Zealand is not available, data on materials from overseas countries that share similar properties to that on New Zealand are used instead.

LCAQuick data is not available for all materials - in these cases a placeholder must be used.

\section{Material Quantities}

For the purpose of this research, material quantities defined as the quantity identified by either the Quantity Surveyor or the REVIT ${ }^{\mathrm{TM}}$ schedule of quantities.

The "level of detail" that goes into modelling can have an impact on the analysed material quantities. While the house model includes from the concrete base slab to the corrugated roof 
finish and all elements in between, each component may be modelled at fine detail e.g. a window by its surround, the aluminium frame, the glazing materials, the glass, the mullion etc., or as main item with a generic per unit value e.g. per square-metre of window

\section{LCAQuick BIM Modelling Framework}

Currently, to produce a BIM model for performance sketch requires excessive modelling time. This is due requiring information all relevant building performance aspects such as, thermal, lighting, and building materials, to allow the calculation of accurate results for each. The outcome is that the BIM model in question becomes ineffective for a building performance assessment due to its time-consuming development.

Therefore, it can be asked that if the model were simplified in development process, could the simulation results still produce reliable data? Research has found that using simulation tools more effectively, to examine different design option quickly, can facilitate design decision-making (Donn, Selkowitz, \& Bordass, The Building Performance Sketch, 2012). This establishes a foothold on the idea that it is possible to construct a "Building Performance Sketch model" that is detailed enough to produce simulation results of one area of building performance which can allow for accurate enough for decision-making, and no more (Donn, Quality Assurance simulation and the real world, 1999) (Berg, 2014). The result of that research showed decreased modelling time and effort, while achieving simulation accuracy requirements.

In this research, this approach is to be applied to an LCAQuick tool format, thus this is a breakdown of what is required to achieve a "Building Performance Sketch model".

\section{Building Performance Sketch}

A Building Performance Sketch is a simplified model that is intended to generate adequate results to meet the current needs.

\section{Using Revit ${ }^{\mathrm{TM}}$ to calculate building material quantities.}

"LCAQuick residential" building materials and quantity as inputs, but while there may be detailed this research is exploring how it might be used as a LCE building performance sketch in the early design process, before the crucial design planning stage of Table 1. The definition of a performance sketch is the approach to sketching building concepts, not a whole building, just using whatever is the most suitable tool to explore the performance implications of the concept (Donn, Selkowitz, \& Bordass, The Building Performance Sketch, 2012). In the case of this research, a CAD programme (REVIT ${ }^{\mathrm{TM}}$ ) serves as the platform in which the data for the performance sketch will be developed. The performance sketch at this point of the research is referred to as the "BIM Model".

\section{BIM Model: The Building Performance Sketch Model}

A Building Information Model (BIM) is the digital representation of physical and functional characteristics of a facility (NBS - What is Building Information Modelling?, 2016) - a REVIT TM $\mathrm{BIM}$ is a BIM model designed using Autodesk Revit ${ }^{\mathrm{TM}}$ software. The design and detail of the BIM model is subject to the designer's intentions as to what they want to design and how much they want to design. The amount of what the designer's wants to design in the context of this research is defined as the Level of Development (LOD) to which this research will explore more in detail. 


\section{Definitions of LOD's}

LOD is often interpreted as Level of Detail rather than Level of Development. Therefore, the acronym "LOD" in this thesis will be defined as "Level of Development" whereas the "LOi" is referred to as the "Level of Detail" instead.

Level of Detail is how much detail is included in the model element. Level of Development is the degree to which the element's geometry and attached information has been thought through (BIM Acceleration Committee, Nov 2016). The LOi can be thought of as an input to the element, while LOD is a reliable output.

Level of Detail: Level of information input

\section{Revit $^{\text {TM }}$ BIM model}

Level of Development: Level of information retained

Figure 5: An illustration to define the difference between "LeVel of DetaiL" (LOI) VS "LEVEL OF DEVELOPMENT" (LOD).

In the case of this thesis, the LOD is the quantity in question when trying to understand at what level of development does a model need to be in order to produce accurate results from LCAQuick Residential. Figure 5 illustrates that the Level of Development is dictated by the Level of Detail. Table 3 lists, and Figure 6 illustrates, the various LOD as defined by the BIM Acceleration Committee, ranging from the least detailed LOD 100 through to the most detailed LOD 500.

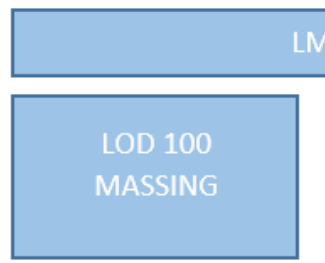

\section{LMD}

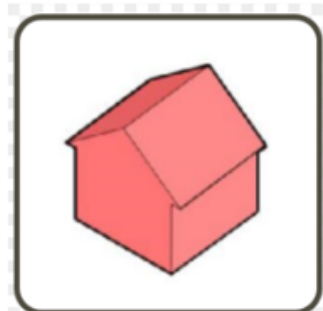

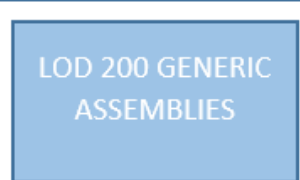

MDM

LOD 300 - 350

SPECIFIED

ASSEMBLIES

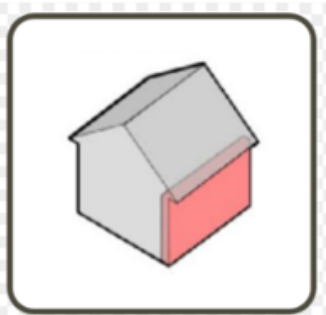

\section{HDM}

LOD 400

DETAILED

COMPONENTS
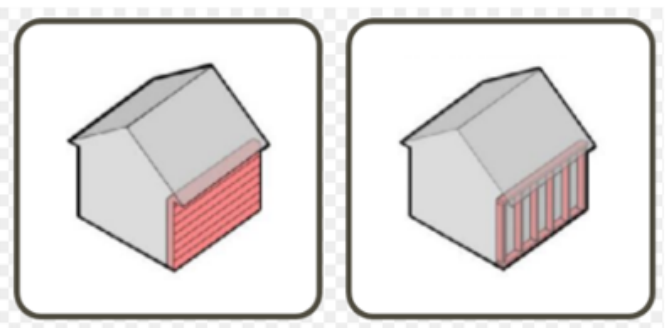

FiguRE 6: EACH MODEL IS A STEP UP IN TERMS OF DEVELOPMENT FROM LOW DETAIL MODEL (LDM), Medium Detall Model (MDM) to High Detall Model (HDM). 
Table 3: Definition of Level of Development (Bim Acceleration Committee, Nov 2016).

\begin{tabular}{|c|c|c|}
\hline Level of Development & Definition & $\begin{array}{l}\text { General } \\
\text { Terms }\end{array}$ \\
\hline LOD 100 & $\begin{array}{l}\text { The Model Element may be graphically represented in the Model } \\
\text { with a symbol or other generic representation, but does not satisfy } \\
\text { the requirements for LOD 200. Information related to the Model } \\
\text { Element (i.e. cost per square foot, tonnage of HVAC, etc.) can be } \\
\text { derived from other Model Elements. }\end{array}$ & $\begin{array}{l}\text { "there is a } \\
\text { thing" }\end{array}$ \\
\hline LOD 200 & $\begin{array}{l}\text { The Model Element is graphically represented within the Model as a } \\
\text { generic system, object, or assembly with approximate in terms of } \\
\text { quantity, size, shape, location, and orientation. Non-graphic } \\
\text { information may also be attached to the Model Element. }\end{array}$ & $\begin{array}{l}\text { "there is a } \\
\text { thing about } \\
\text { this size" }\end{array}$ \\
\hline LOD 300 & $\begin{array}{l}\text { The Model Element is graphically represented within the Model as a } \\
\text { specific system, object or assembly in terms of quantity, size, shape, } \\
\text { location, and orientation. Non-graphic information may also be } \\
\text { attached to the Model Element. }\end{array}$ & $\begin{array}{l}\text { there is a } \\
\text { thing with } \\
\text { these } \\
\text { functions and } \\
\text { options" }\end{array}$ \\
\hline LOD 350 & $\begin{array}{l}\text { The Model Element is graphically represented within the Model as a } \\
\text { specific system, object, or assembly in terms of quantity, size, shape, } \\
\text { orientation, and interfaces with other building systems. Non-graphic } \\
\text { information may also be attached to the Model Element. }\end{array}$ & $\begin{array}{l}\text { there is a } \\
\text { thing with } \\
\text { these } \\
\text { functions and } \\
\text { options" }\end{array}$ \\
\hline LOD 400 & $\begin{array}{l}\text { The Model Element is graphically represented within the Model as a } \\
\text { specific system, object or assembly in terms of size, location, } \\
\text { quantity, and orientation with detailing, fabrication, assembly, and } \\
\text { installation information. Non-graphic information may also be } \\
\text { attached to the Model Element. }\end{array}$ & $\begin{array}{l}\text { "it is this } \\
\text { particular } \\
\text { thing" }\end{array}$ \\
\hline LOD 500 & $\begin{array}{l}\text { The Model Element is a field verified representation in terms of size, } \\
\text { shape, location, quantity, and orientation. Non-graphic information } \\
\text { may also be attached to the Model Elements. }\end{array}$ & $\begin{array}{l}\text { "this } \\
\text { particular } \\
\text { thing provided } \\
\text { by this person } \\
\text { on this date" }\end{array}$ \\
\hline
\end{tabular}




\section{Chapter 3: Research Methodology}

The previous chapter provided the literature review that set the course for the purpose of this research. This involved the understanding of the fundamentals of the LCAQuick tool and its broad use in the industry. A highlighted point of interest was its new application towards residential housing through new developments although the issue of its complexity in use persists. The purpose of this chapter is to justify an appropriate method of research to further understand how to investigate this issue so the results may form some means of answering the research question of this paper.

\section{Research Method Selection Reasoning}

The LCAQuick residential tool is still in its infancy, so it is being tested by analysing a large number of residential housing projects before its planned release in 2018. As at the time of writing (October 2017), the tool demands quality detail to produce accurate and reliable results, i.e. LOD 350 and upwards.

Although the original plan was to explore the differences in output from the use of different LOD input levels, it was found that it was not possible to generate LOD 400 to 500. An LOD 400 would require topographical information on the location of the House to be included whereas LOD500 would require time and budget details in addition to the LOD400 requirements. As the studied house was not on a specific site, this level of detail was not possible. Therefore, an LOD 350 has been used.

\section{Qualitative Research Method}

The purpose of using qualitative research method is to emphasize on the understanding of an underlying problem. As stated by (Atieno, 2009), the main concept of a qualitative approach is to highlight perspectives on a certain subject that is difficult to establish in advance and a deeper understanding of the subject therefore needed. However, in the case of this research a qualitative approach will not be employed as the underlying problem has been identified and therefore setting of the research changes to an objective approach. Thus, this method is not appropriate for this research.

\section{Specification of Research Method and its Limitations}

"Simulation Based Research" was selected as the research methodology due to its specific nature to explore processes and mechanisms of simulation chains (Gilbert \& Troitzsch, 2005). Figure 7 shows the steps in a simulation based study.

Simulation Based Research develops a model of a process, and then perform trials on the model to predict the outcomes over repeated runs. However, the process does provide a specific answer but rather delivers a set of the system's responses to different operating conditions (Davis \& Eisenhardt, 2007). In this research, it may lead to difficulty in finding the optimal solution or specific values of simulation due to a varying number of parameters, which could also mean different solutions, can be produced in testing enlarging the scope of intended outcomes. 


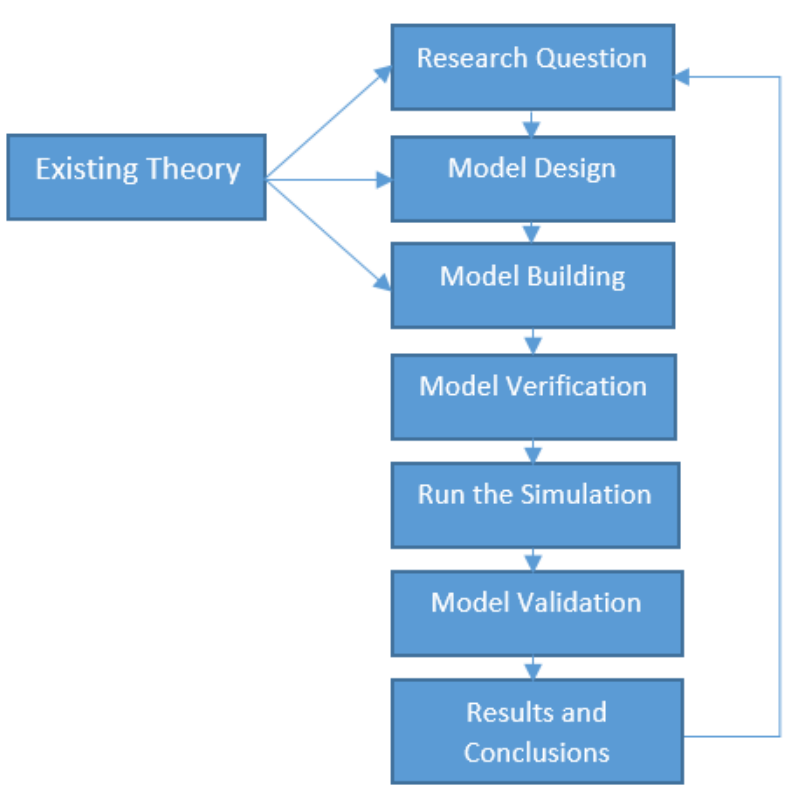

FiguRE 7: SimULATION BASEd RESEARCH LAYOUT THAT WILL BE USED IN THIS STUdY. SOURCE: (ROSE, SPINKS, \& CANHOTO, 2015).

The purpose of simulation based research is to help gain a better understanding of a phenomenon of interest and for the purposes of prediction (Gilbert \& Troitzsch, 2005). To further this, the research method is ideal when the interest is in the processes and mechanisms. Therefore, the understanding of the mechanisms of the LCAQuick tool through simulation processes shall determine from the results a conclusive solution for the research question proposed.

\section{Research Question}

The research question of this paper is "Can a REVIT TM BIM model produce consistent results for an LCAQuick calculation?" and therefore dictates the direction of the research method. The question focuses on the "level of detail required of a BIM model" and therefore the method must emphasize on what the BIM model must explore through testing.

\section{Model Design}

Model design involves specification of the target to be modelled in the simulation and the selection of an appropriate simulation method. The following are the definitions of parameters for the Model Targets that the models are required to meet and the Simulation Method that they will be subjected to.

\section{Model Targets}

To establish a point of validity in the results the testing method will require empirical data based results for comparison. Figure 8 illustrates how a Truth Model will be designed using information from a Quantity Surveyor and a Test Model using the data from a Revit ${ }^{\mathrm{TM}}$ house model based on the drawings. The outputs from these models will be schedules of material quantities that will be used in the LCAQuick Residential tool. 


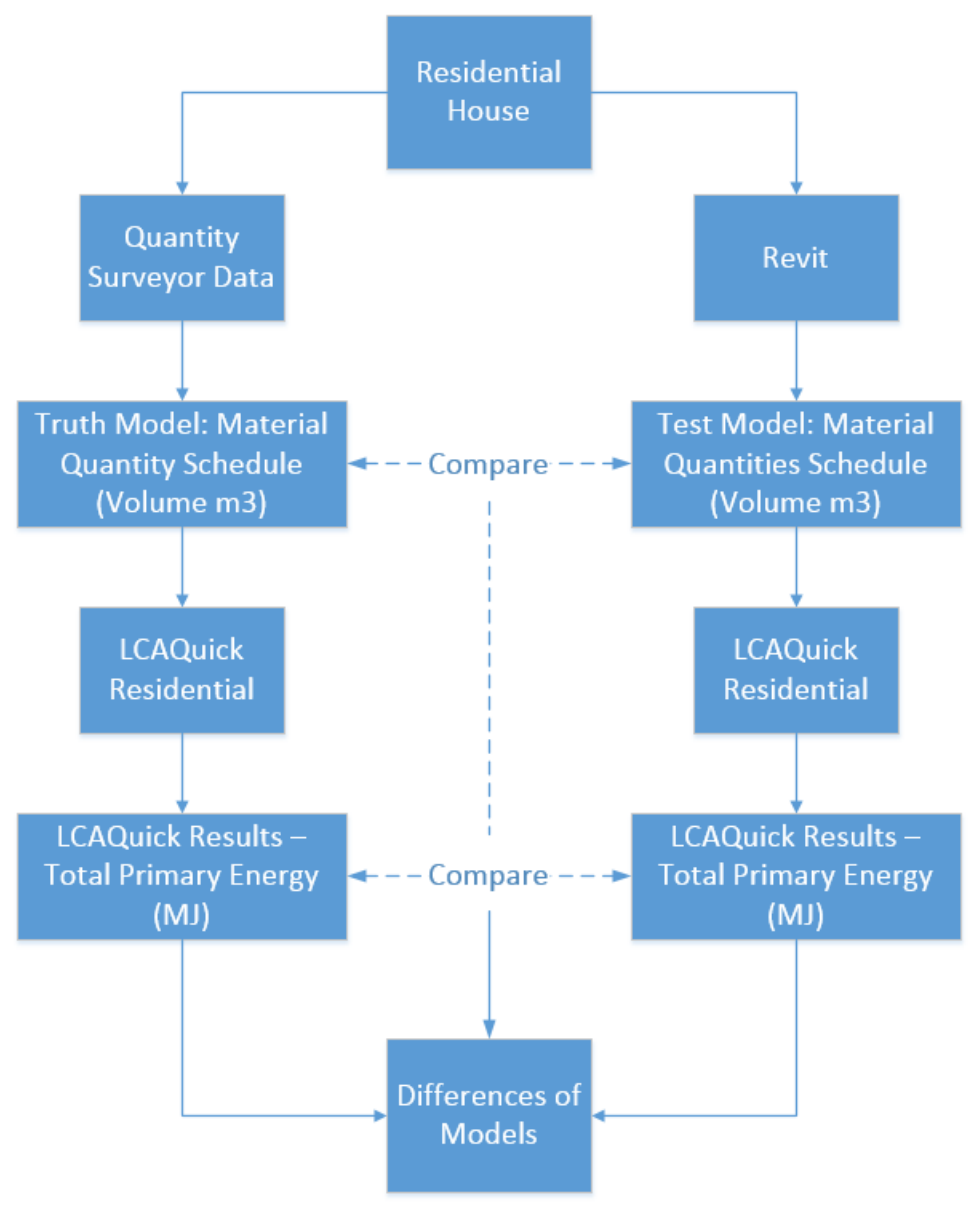

FiguRE 8: RESEARCH METHOdOLOGY

Model Types

One residential house, provided by BRANZ, will be modelled in this research, as a Truth Model and a Test Model. The model types will both follow LOD 350 (see Table 3). 


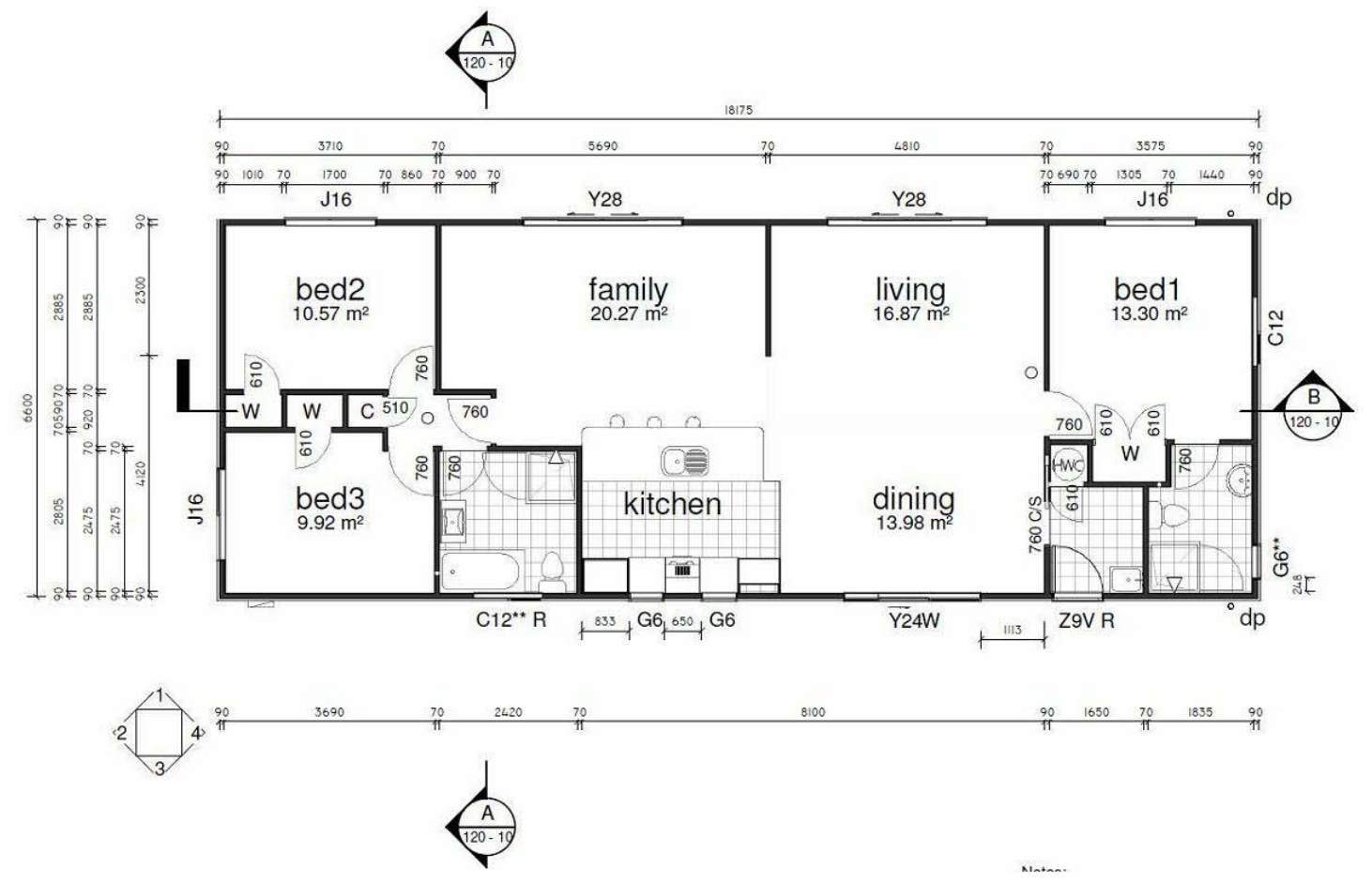

Figure 9: Floor Plan Of SELECTEd Home

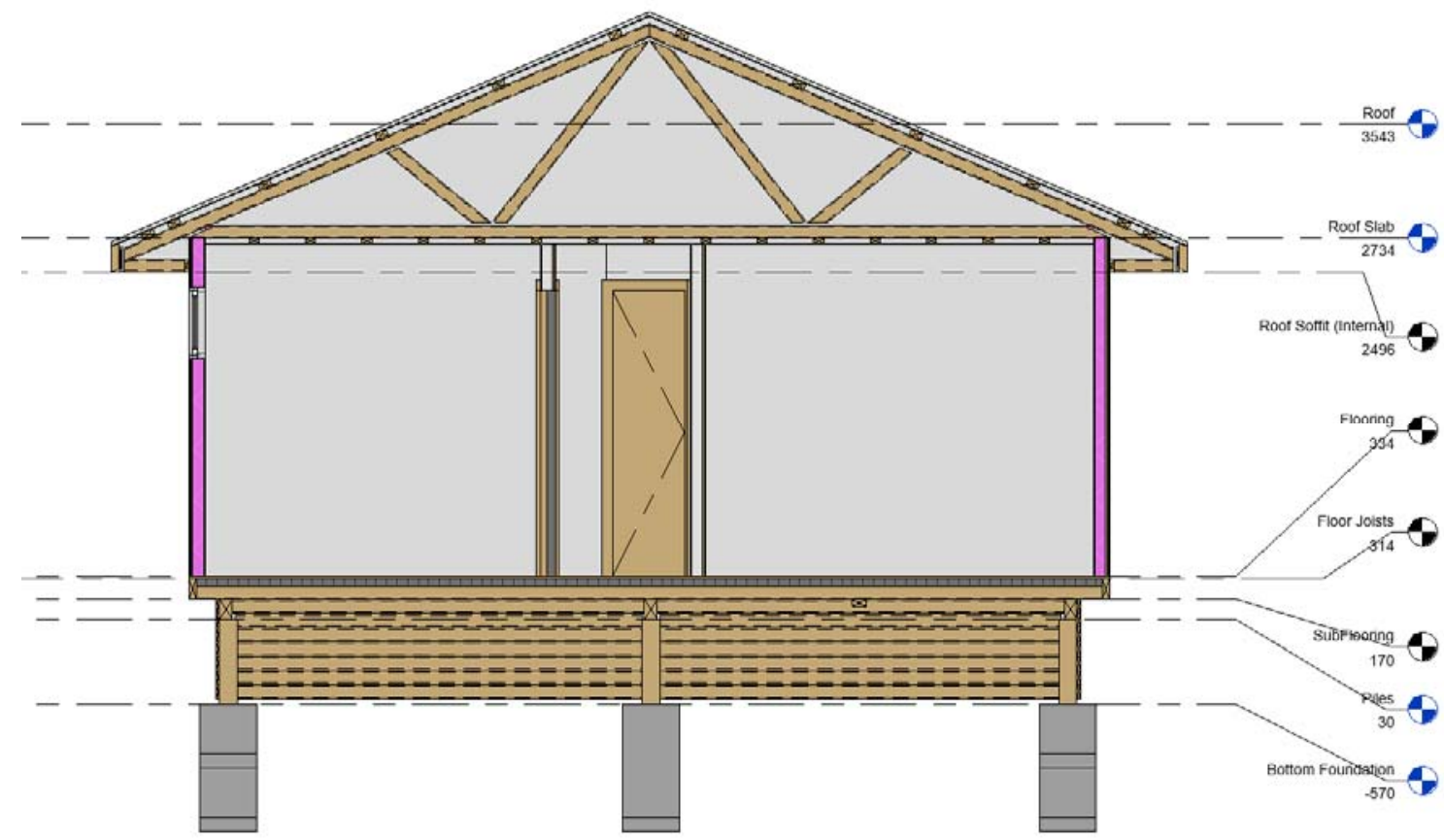

Figure 10: Section View of Selected Home

\section{Truth Model}

The purpose of the Truth model would be for its real world comparison due to the nature of its realistic data as it is based on the Quantity Surveyor material quantities schedule. Some processing of the data was required to align with the requirements of the LCAQuick tool. Any 
materials that do not have a corresponding material coefficient in LCAQuick was substituted with a placeholder. In some cases the level of detail generated by the Quantity Surveyor is beyond that able to be determined form the Revit model e.g. quantity of nails. The data collected from the Quantity Surveyor was considered as the empirical data.

\section{Test Model}

The Test model will be based on a LOD 350 to determine whether this generates an adequate level of material quantity for a LCAQuick Residential result simulation.

\section{Simulation Methods}

Figure 11 describes the simulation method for the Truth Models where the initial design stage requires the formatting of the Quantity Surveyor data to a suitable format for LCAQuick. The Model building stage involves the formatting of the data to LCAQuick ready format. The outcome would be a Schedule sheet that aligns the material and their volumes. This is the key point of turn over where the schedule provides the means of running the LCAQuick tool in "Run the Simulation" stage. The results produced will determine the Total Primary Energy consumption of the House design.

Figure 12 follows the same process for the Test Model, however its Model Validation stage uses the QS data for categories and the house drawings to guide the Revit design for the BIM. The Model Building stage is the actual development of the BIM model (Test Model) within Revit using the software tools and set parameters. The Revit feature "Material Take-off Schedule", produces a Material Schedule with volume details for the LCAQuick simulation stage to commence where the Total Primary Energy of the Test Model can be calculated. 



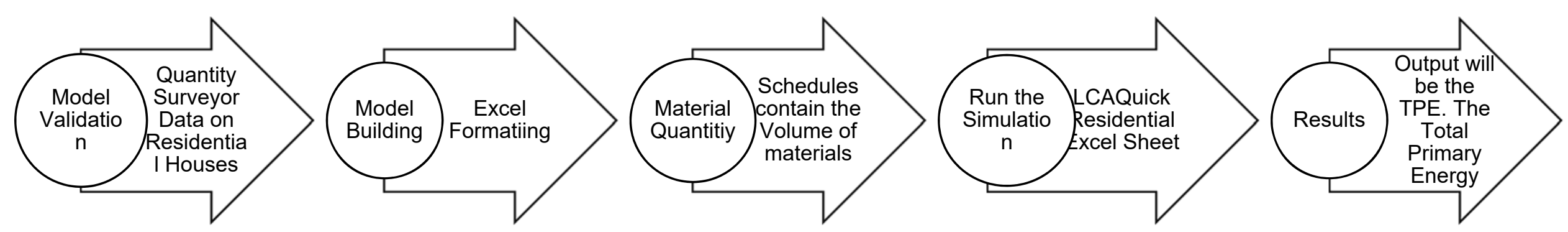

Figure 11: Truth Model Process of Modelling and Simulation to produce Results

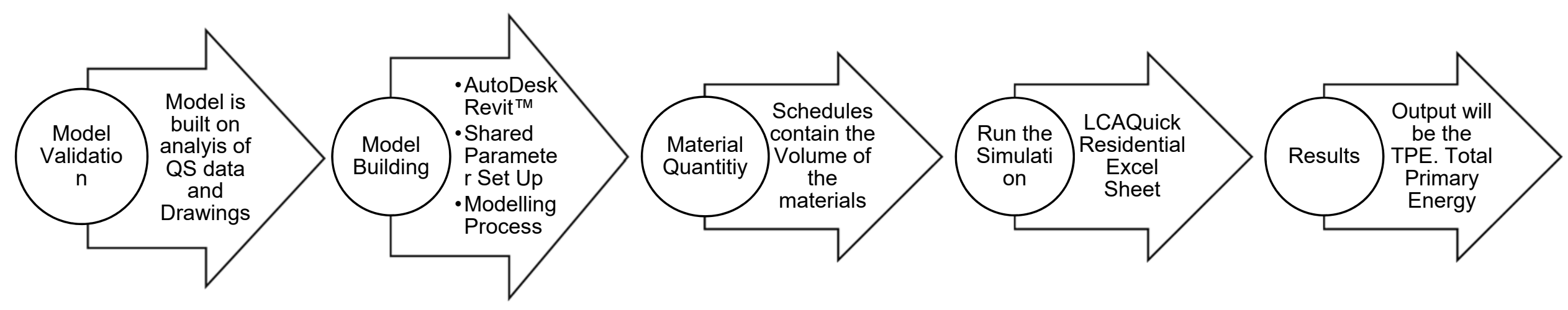

Figure 12: Test Model Process of ModelLing ANd Simulation to PROduce Results 



\section{Model Building}

The next step is the Model Building stage. As defined by the "Model Design" step, the parameters for both the Truth Model and Test Model are already established and therefore the Models will be designed based on the one real life residential house selected for this research thesis. This house was selected as full Quantity Surveyor Materials Schedule was available.

\section{Autodesk Revit ${ }^{\mathrm{TM}}$ :}

Autodesk Revit ${ }^{\mathrm{TM}}$ is building information-modelling software developed by Autodesk for Architects, Engineers and Construction individuals. The program houses a 3D environment for users to design and annotate building structure and components with access to building information from the building model's database.

The Autodesk Revit ${ }^{\mathrm{TM}}$ software is a versatile BIM designing program and has no one-way-means of designing a BIM model. As there are many ways to skin a cat, in Revit ${ }^{\mathrm{TM}}$ a BIM model can be built from ground-up or top-down depending on the user's preferences or goals, however for this research the intent of BIM use is to create a means of recording and transferring the material quantities to LCAQuick residential. Therefore, a process of Model Building needs to be established to enable coherent and consistent data collection, model and information assimilation between Revit ${ }^{\mathrm{TM}}$ and LCAQuick Residential.

\section{Model Building Process}

1. Establish the Residential House for modelling and collect all relevant information on the construction e.g. Quantity Surveyor Schedule of Quantity, Architects Drawings.

2. Define the "Truth Model" or "Test Model".

a. "Truth Model"

All information on the selected residential house should be recorded in the

Quantity Surveyor Data sheet.

i. All materials are readily available and are formatted to align with LCAQuick Schedule Headings.

b. "Test Model"

Using the Information of the QS data and the support of the House drawings, the Revit process are to be as followed in Step 3.

i. Create the Parameters for Revit ${ }^{\mathrm{TM}}$ to collect information known as "General Parameters". General parameters are parameters that those used by most all elements in the Revit ${ }^{\mathrm{TM}}$ Model. Most schedules produced will have these Parameters as main headers that categorize the information need by LCAQuick.

\section{Produce Schedules}

a. "Truth Model Material Quantity Schedule"

By formatting the QS data sheet, the result itself would be a LCAQuick ready schedule.

b. "Test Model Material Take-off Schedule" Using Revit ${ }^{\mathrm{TM}}$ schedule function to generate the appropriate schedules required by LCAQuick Residential to simulate. 


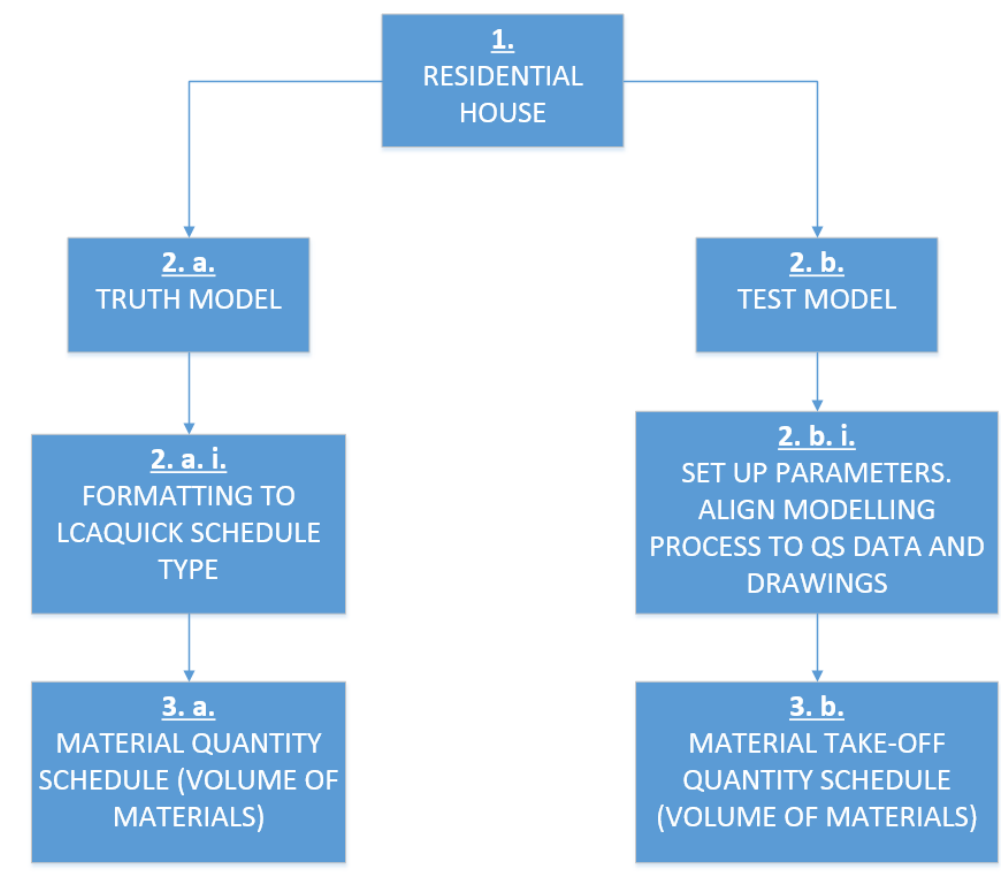

Figure 13: The Model BuILDING PROCESS that Dictates the PATH BOth MODELS WILL BE DESIGNED TO, PRIOR THE SIMULATION STEP OF RESEARCH METHOD. FIRSTLY, ESTABLISH THE HOUSE TO BE MODELLED AND THEN CREATE THE PARAMETERS FOR DATA SPECIFICATION IN SCHEDULES AT THE END (RED HIGHLIGHT. BOTH TRUTH MODEL AND TEST MODEL WILL BE REQUIRED TO PRODUCE SCHEDULES THAT WILL BE EXPORTED TO EXCEL - LCAQUICK RESIDENTIAL FOR SIMULATION.

\section{Autodesk Family Objects Download}

When downloading the Families from the Online Object Library changes were made to the Objects/ Families to allow them to output the relevant information needed for Material Quantity Schedule. They were also adjusted to suit the dimensions of the selected home, an existing New Zealand house built to NZ Building Code. This would therefore make the object/family NZ standard friendly. In addition, any library object/ family found with empirical format was easily changed to metric using Revit settings.

\section{Autodesk Revit ${ }^{\mathrm{TM}}$ Schedules}

The Schedules in Revit ${ }^{\mathrm{TM}}$ captures and outputs all necessary material information for the 3D modelled house. Figure 13 illustrates the layout requirement of the schedules with the Schedule Classes and their subheading as Schedule Types to classify the material quantities of each component of the BIM model. 
Table 4: Revit ${ }^{\mathrm{TM}}$ Schedule Format

\begin{tabular}{|c|c|}
\hline REVIT $^{\mathrm{TM}}$ SCHEDULES & Definition \\
\hline MATERIAL TAKE-OFF & $\begin{array}{l}\text { A Material take-off Schedule is required to remove the information of } \\
\text { materials of elements in the model only. }\end{array}$ \\
\hline Door Schedule & \multirow{8}{*}{$\begin{array}{l}\text { The Individual level of Elements that by default, Revit }{ }^{\mathrm{TM}} \text { extracts the } \\
\text { material information from }\end{array}$} \\
\hline Floor Schedule & \\
\hline Roof Schedule & \\
\hline Structural Column Schedule & \\
\hline Structural Framing Schedule & \\
\hline Wall Schedule & \\
\hline Window Schedule & \\
\hline SOQ Window Material Take-off & \\
\hline
\end{tabular}

*SOQ - Schedule of Quantity:

\section{Model Verification}

Verification Involves running the simulation and testing whether or not the model is working, as it should. If there, any problems with the simulation these should be corrected (Gilbert \& Troitzsch, 2005). This step is crucial in ensuring quality of results are to be trusted and usually carried out in the turn over phase between Revit ${ }^{\mathrm{TM}}$ and LCAQuick Residential - the schedules transfer as well as LCAQuick tool simulation checks for previous installed data.

\section{Run the Simulation}

Simulations are virtual experiments during which series of 'experiments' are run under different the conditions that can be varied as required (Davis \& Eisenhardt, 2007). As mentioned in section dealing with the model LOD, there will be two iterations of model designed for simulation to satisfy an array of altering conditions. Therefore, simulation will have to adhere to a structure of simulation conditions to quantify and classify the results. This will highlight an array of results differences that will indicate any areas of interest during "Chapter 6: Accuracy Assessment"

\section{Schedule Conditions}

- Schedule Heading Alignment

- Schedule Naming Format Required for ease of data Turn over between Revit ${ }^{\mathrm{TM}}$ and LCAQuick

\section{LCAQuick Conditions}

- LCAQuick Repository Data Clear before every use

- Refresh and Restart LCAQuick to make sure it is able for new simulation before every start - any indication of environmental impact indicates repository data

\section{Model Validation}

Validation involves confirming that the simulation is a good representation of the chosen target. This is done by comparing results of the simulation with empirical data (Gilbert \& Troitzsch, 2005). This is the purpose of the Truth Model, which uses the data from Quantity surveyors as a realistic basis for design. To further the importance of the model validation (Pidd, 2004) highlights, it is vital a model is sufficiently credible that people are confident to act on the insights it produces. Credibility, (Gilbert \& Troitzsch, 2005) suggest, is established over time by the model-building process, the actions of the researches and the insights offered by the simulation.

\section{Simulation Accuracy}

An additional rule of thumb when it comes to developing an BIM model relation to building performance is to base the decisions making on the performance indicators calculated by 
building performance simulation tools. However to base decisions on these results, the building designer must trust them (Donn, Quality Assurance - simulation and the real world, 1999). Therefore, it comes down to a measure of "Trust". To do so would require measures of simulation reliability presented in Table 5 . This sets achievement criteria for critical components in a simulation methodology.

TABLE 5: MeAsure of SimUlation ReliabiLITY FOR DESIGN DECISION-MAKING. SOURCE: (BERG, 2014) (Donn, Selkowitz, \& Bordass, The Building Performance SKetch, 2012) (ASHRAE GuIDELINE 2002: MEASUREMENT Of ENERGy AND DeMAND SAVINGS. , 2002)

\begin{tabular}{|c|c|c|}
\hline $\begin{array}{l}\text { Measures of Simulation } \\
\text { reliability }\end{array}$ & Definition & Research Model validity \\
\hline $\begin{array}{l}\text { Simulation } \\
\text { completeness }\end{array}$ & $\begin{array}{l}\text { It is a measure of the simulation scope, or } \\
\text { how much of a building's total } \\
\text { consumption the simulation results } \\
\text { represents. }\end{array}$ & $\begin{array}{l}\text { The results of the LCAQuick } \\
\text { Simulation of both Truth and Test } \\
\text { Model will set to accomplish this } \\
\text { stage of Simulation Completeness }\end{array}$ \\
\hline Simulation accuracy & $\begin{array}{l}\text { The measure of 'how close' simulation } \\
\text { results (values) are to the measured } \\
\text { performance of the building in reality } \\
\text { These measurements of reality are called } \\
\text { 'true values'. Simulation accuracy is the } \\
\text { product of all the simulation errors caused } \\
\text { by uncertainties. }\end{array}$ & $\begin{array}{l}\text { In this research, the Simulation } \\
\text { accuracy is achieved by the use of } \\
\text { Real Life Data i.e. Quantity Surveyor } \\
\text { Data and Drawings. This will align the } \\
\text { modelling process of the Test Model } \\
\text { to drive towards a realistic } \\
\text { representation of the real deal. }\end{array}$ \\
\hline Simulation precision & $\begin{array}{l}\text { An expression of the closeness of } \\
\text { agreement among repeated measurements } \\
\text { of the same physical quantity accounting } \\
\text { for offsetting or cancellation errors that } \\
\text { occur when a model is over or under } \\
\text { simulation results. }\end{array}$ & $\begin{array}{l}\text { The requirement of precision for } \\
\text { both models is that any excess of } \\
\text { materials that do not match must be } \\
\text { excluded and removed from test } \\
\text { stages of the Research. This will only } \\
\text { align those materials that can be } \\
\text { modelled and simulated for a precise } \\
\text { alignment of parameters. }\end{array}$ \\
\hline Simulation Robustness & $\begin{array}{l}\text { A simulation robustness is a type of } \\
\text { sensitivity analysis. It identifies any } \\
\text { unexpected sensitivities or hidden errors in } \\
\text { simulation inputs, and in the simulation } \\
\text { calculation process, which may arise in } \\
\text { different design iteration or scenarios. } \\
\text { Robustness assessment tests to ensure } \\
\text { that slight changes in the simulation inputs } \\
\text { do not result in an unacceptable level of } \\
\text { simulation accuracy, or not achieving } \\
\text { performance goals. }\end{array}$ & $\begin{array}{l}\text { A repeat of simulation runs will be } \\
\text { required to breakdown the level of } \\
\text { analysis that needs to take place for } \\
\text { an elemental analysis. Provided that } \\
\text { the Quantity Surveyor Data is robust, } \\
\text { it will still need to be broken down to } \\
\text { the elemental level. Each element of } \\
\text { both models must be on a separate } \\
\text { level to understand their individual } \\
\text { elemental contribution. }\end{array}$ \\
\hline
\end{tabular}




\section{Chapter 4: The Methodology of Testing}

The purpose of this chapter is to document and analyse the method of testing undertaken to analyse the research question.

\section{BIM Sketch Design Decision-Making}

Any process of construction development has decisions made throughout every stage of its lifecycle. These so-called "decisions" are the focal points that determine whether the construction is capable of achieving its performance goals. In Table 1 this would fall in the "Crucial Planning" stage. Therefore, a concept of "good sketch design decisions" is a means of early determination of a building information (Berg, 2014). A rule of thumb in this process of determining "good sketch design decisions" is to base such decisions on relevant data that will allow for a realistic guide for the design to be used during modelling processes.

Whichever the case it is critical to know the decisions that must be made during early sketch design, and those that can be made later in the design process. Some modifications such as fine tuning, and optimisation of sketch design decision can be made later in the design process, but to meet performance goals, the fundamentals of building's design that are decided upon at sketch design cannot change (Augenbroe, 2002).

\section{Requirements of Sketch Design}

An LCAQuick demands a sketch model to provide the information of an already modelled house, the question becomes, "what does a BIM modelled house have to provide?" or "what is a definition of a BIM house?" Therefore, a clear understanding of what should be modelled within BIM performance sketch must be established.

The importance of defining "what needs to be modelled" allows LCA processes to produce results that are reliable enough for design decision making. Although the issue can be categorized as what "Level of Development" is required, the issue is more refined at this point as to "What is required" from both the Truth and Test Model.

\section{Parameters of Model Design}

Constructing a BIM, requires taking a building's design as expressed as project documentation drawings (floor plans, elevation, sections and details), schedules and specifications, and turning that into a BIM model e.g. BIM objects and BIM building geometry. The distinction between BIM objects and BIM building geometry is related to the hierarchy of how they organise building materials and products. BIM objects are the lower of the two. They deal with materials and products at an individual level, often assembling (referred to as layering) them into a collection representing a specific construction system. Embedded within each BIM object is metadata such as, the cost, the manufacturer, the building classification system description and code, and material properties like density and energy efficiency. In this way the information calculable from a BIM model is entirely dependent of data inputs is entered into the BIM objects.

The process of constructing a BIM model starts with constructing the BIM objects, and then arranging them into the building's overall form called the BIM building geometry. Methods for constructing BIM objects and geometry depend on the specific BIM tool being used. In Revit ${ }^{\mathrm{TM}}$, BIM objects are created using the 'Family Builder', and the BIM building geometry is constructed (hereby referred to as modelled) using the modelling tools shown in Figure 14. 
As an alternative to the time consuming task of creating BIM objects, many are freely downloadable from online databases called BIM libraries. One example is the National Building Specification's National BIM Library where a majority of building elements are readily premade in geometry but must be altered in parameters to suit any design intentions set by the user (NBS What is Building Information Modelling?, 2016)

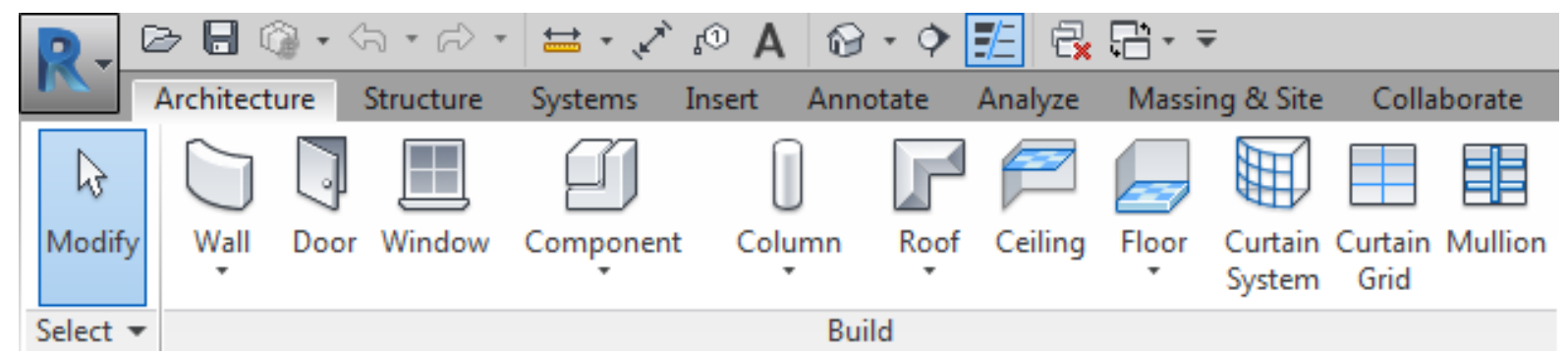

FIGURE 14: BIM REVIT ${ }^{\text {TM }}$ MODELLING TOOLS MENU BAR

\section{Calculating Building Material Quantities from the BIM model}

After constructing the BIM objects, and BIM geometry, the subsequent step in the modelling methodology is the calculation of the building material quantities from the BIM model. This is an automated process conducted by using the BIM scheduling tools.

While using these tools makes the calculation easier, and faster, it also means that the quantities that can be calculated and the unit format of their description are limited by the functional capabilities of the BIM tool. Figure 14 lists the Revit ${ }^{\mathrm{TM}}$ building elements (BIM objects), and the quantity information that can be calculated using its Material Take-off and Schedule / Quantities tools, showing there is a variation in the calculable units of material quantities across the different building elements.

TABle 5: Calculated Quantity INFORMation AVAilable Using ReVIT ${ }^{\text {TM }}$

\begin{tabular}{|l|l|}
\hline $\begin{array}{l}\text { Revit } \\
\text { Types }\end{array}$ & Qamily \\
\hline Wall & Length, Area, and Volume \\
\hline Roofs & Thickness, Area, and Volume \\
\hline Ceilings & Perimeter, Area, and Volume \\
\hline Floors & $\begin{array}{l}\text { Thickness, Perimeter, Area, and } \\
\text { Volume }\end{array}$ \\
\hline Columns & Width, depth, and Volume \\
\hline Beam & Width, and Volume \\
\hline Foundation & Length, Width, and Volume \\
\hline Doors & Thickness, height, and Width \\
\hline Windows & Height, and Width \\
\hline
\end{tabular}

The Table 6 above illustrates the quantity information that each Revit ${ }^{\mathrm{TM}}$ element will contain. These elements however need only capture as much information as can be modelled. Figure 15 below shows the overall depiction of how the process of modelling in the Material Quantity Information with the addition of the Material Coefficients of LCAQuick, will produce the output from the Revit ${ }^{\mathrm{TM}}$ model known as the schedule. What the overall image does not depict is the amount of information that is modelled, in other words the amount of detail modelled determines the amount of Material Quantity that can be captured by the model. 


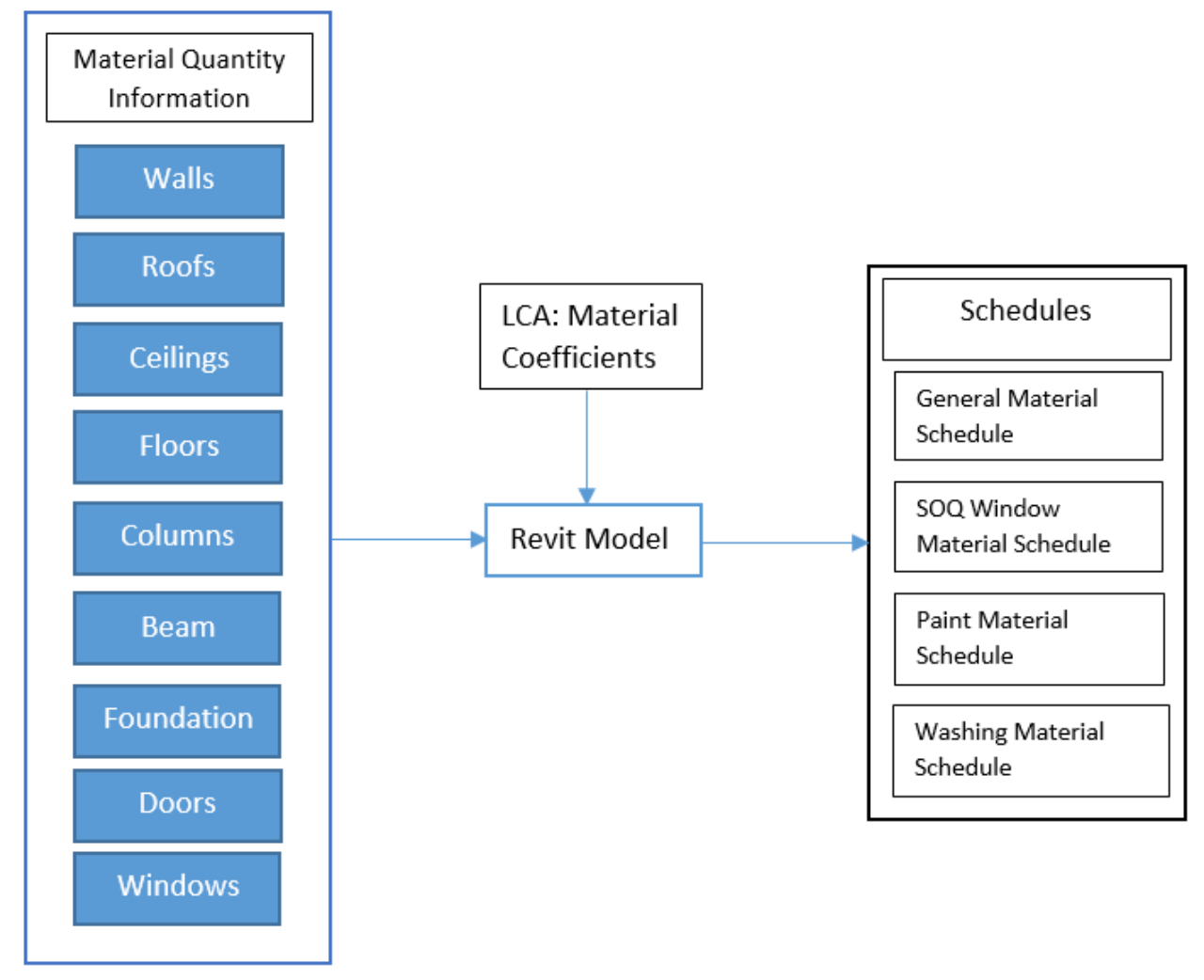

FIgURE 15: PROCESS OF MATERIAL QUANTITY INPUT INTO REVITTM MODEL WITH MATERIAL COEFFICIENTS OF LCAQUICK TO OUTPUT REVIT ${ }^{\text {TM }}$ SCHEDULES.

Therefore, to delve deeper into this query of "how much can be modelled" to capture the necessary information, each Revit ${ }^{\mathrm{TM}}$ element must be elaborated on within this chapter. This elaboration will include in depth how the element is to be designed and at to what extent they have been design to. The extent of the modelling processes is set by the level of detail, whether be it medium definition or high definition, the definitions themselves set the parameters for the extent of modelling.

\section{The Test Model: Details of Modelling}

The details of modelling are the unique parameters that were set within this research for an ease of modelling process to design a suitable Building performance sketch model. These parameters apply to the Wall, Roof, Window and Doors design as these elements or family groups in particular demanded more attention in design for the upmost efficient information capture in design.

\section{Wall (Ratio)}

To align the wall modelling of the Test model to the Truth model would require the modelling of the wall to identify individual timber stud members that form the house frame. This would have been a time consuming process to model and therefore a simpler method was implemented. This was the concept of "Wall ratio of materials" Where instead of individual members modelled, a composite wall was designed with layers introduced accounting for the ratio of the materials that made up the composition from the either QS data or Drawings. 


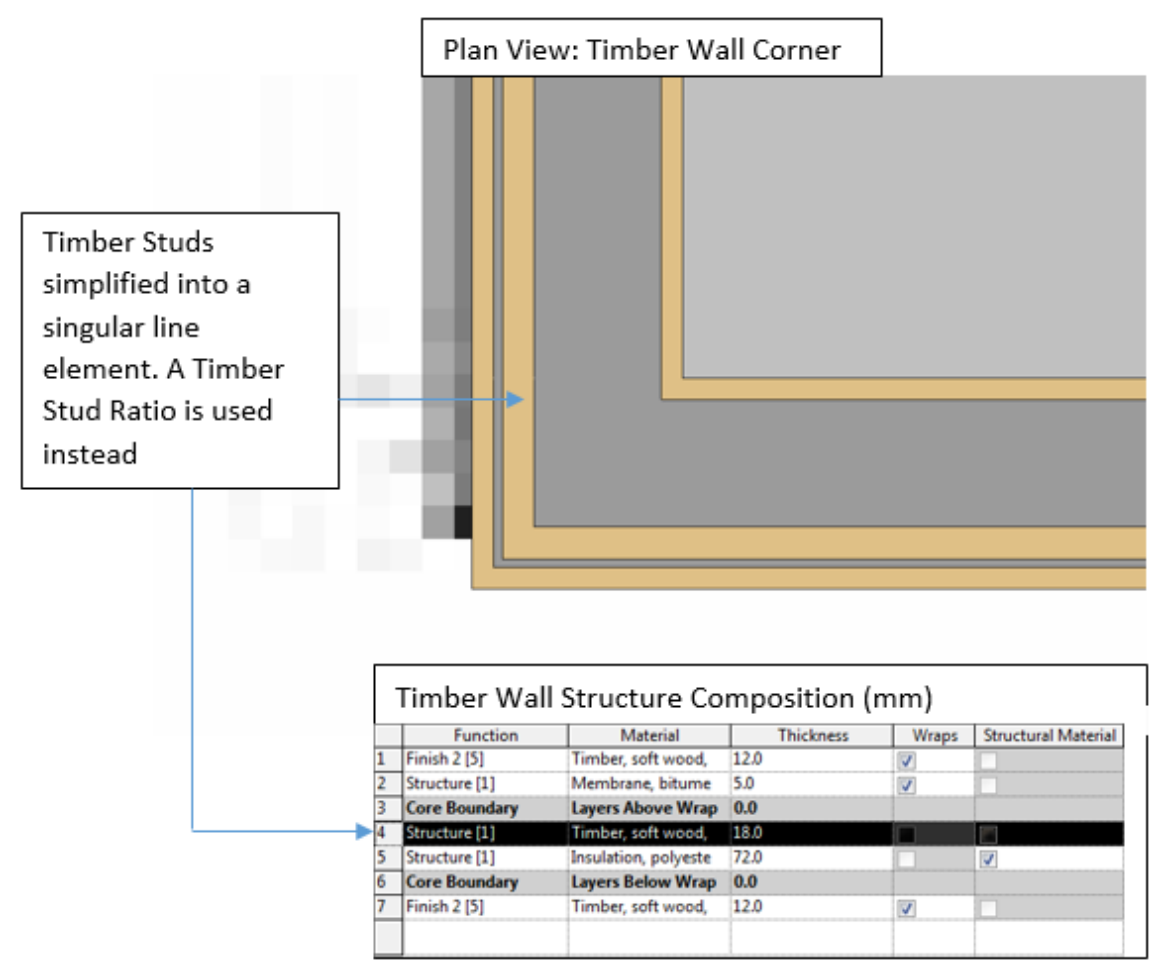

FIGURE 16: AN EXAMPLE OF HOW TO MODEL A WALL IN A SIMPLE BUILDING PERFORMANCE SKETCH WHERE A RATIO OF MATERIALS IS USED INSTEAD OF INDIVIDUAL MEMBER MODELLING.

The modelling of wall is a simpler task as it requires the use of wall element ratios. The term "ratios" or "element ratios" used in this context is defined by the amount of an element in the entirety of the overall structure composition. For example, a total wall thickness in figure (above) is 90 , therefore to account for the timber studs that are networked around void spaces the insulation occupying a ratio is taken from Figure 17 (BRANZ, 2014).

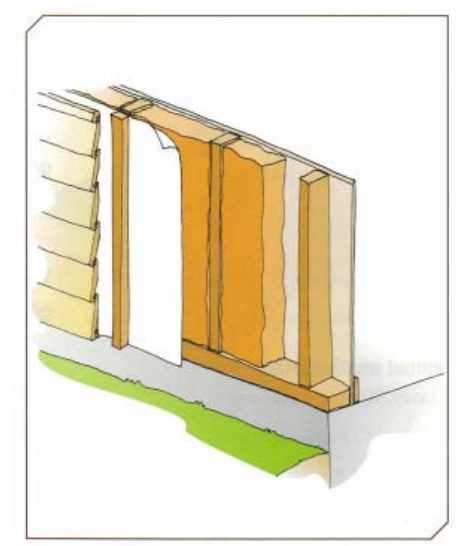

\begin{tabular}{|l|l|l|l|l|l|l|l|}
\hline & \multicolumn{7}{c|}{ Insulation material R-value } \\
\hline & 1.8 & 2.0 & 2.2 & 2.4 & 2.6 & 2.8 \\
\hline & \multicolumn{5}{c|}{ Construction R-value } \\
\hline studs 600, dwangs $800(14 \%)$ & 1.9 & 2.0 & 2.1 & 2.2 & 2.3 & 2.4 \\
\hline studs 600, dwangs $600(16 \%)$ & 1.8 & 1.9 & 2.0 & 2.1 & 2.2 & 2.3 \\
\hline studs 400, dwangs $800(18 \%)$ & 1.8 & 1.9 & 2.0 & 2.1 & 2.2 & 2.2 \\
\hline studs 400, dwangs $600(20 \%)$ & 1.8 & 1.9 & 1.9 & 2.0 & 2.1 & 2.2 \\
\hline (22\%) framing ratio & 1.7 & 1.8 & 1.9 & 2.0 & 2.0 & 2.1 \\
\hline (24\%) framing ratio & 1.7 & 1.8 & 1.9 & 1.9 & 2.0 & 2.0 \\
\hline
\end{tabular}

\section{Notes}

1. All insulants should be placed against wall underlay without pushing the underlay into the cavily

2. $R 3,0$ is the highest practicable $R$-value of common insulation materials that can be used with $90 \mathrm{~mm}$ studs

Figure 17: A Generic BeVel Back Weatherboard fRAming Ratio table .

The ratio is determined by defining the studs and dwang spacing along with construction R-value, where in this case it is studs 400 and dwang is 600 with an estimated R-value of $2.0 \mathrm{~m}^{2}{ }^{\circ} \mathrm{C} / \mathrm{W}$. Therefore, the timber within the wall would have a ratio of $20 \%$ of the entire wall. 
Calculating the Timber thickness within the wall:

$\begin{aligned} P & =20 \% / 90=0.2 \\ T & =0.2 * 90 \\ \underline{T}=18 \mathrm{~mm} & \underline{\underline{T H E C A L A T O N}}\end{aligned}$

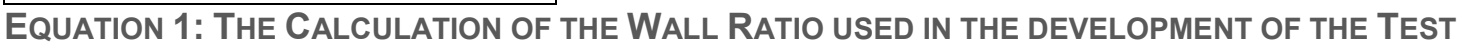
MODEL

Therefore, the internal wall thickness comprises of:

\begin{tabular}{|ll|}
\hline Timber, softwood $=$ & $18 \mathrm{~mm}$ \\
Insulation, polystyrene $=$ & $72 \mathrm{~mm}$ \\
Overall Wall Composition $=$ & $90 \mathrm{~mm}$ \\
\hline
\end{tabular}


It was discovered that the Roof consisted of a multitude of materials that would offer more insight of roof construction impact if they were modelled individually instead of using ratios as in the case of Walls. The highlight of Figure 18 is that all timber elements are modelled separately and due to their uniform linear nature i.e. Battens \& Purlins, it was easy to duplicate each member to the corresponding number requirement of the drawings. The same was done for the Trusses as well as the Soffit and Fascia.

Now this step would be difficult for the Walls as the non-uniform nature of their design stems from Door and Window openings that would demand the design of cuts in timber members. However, Revit ${ }^{\mathrm{TM}}$ alleviates this by allowing an automatic cut in the Walls for Doors and Windows.

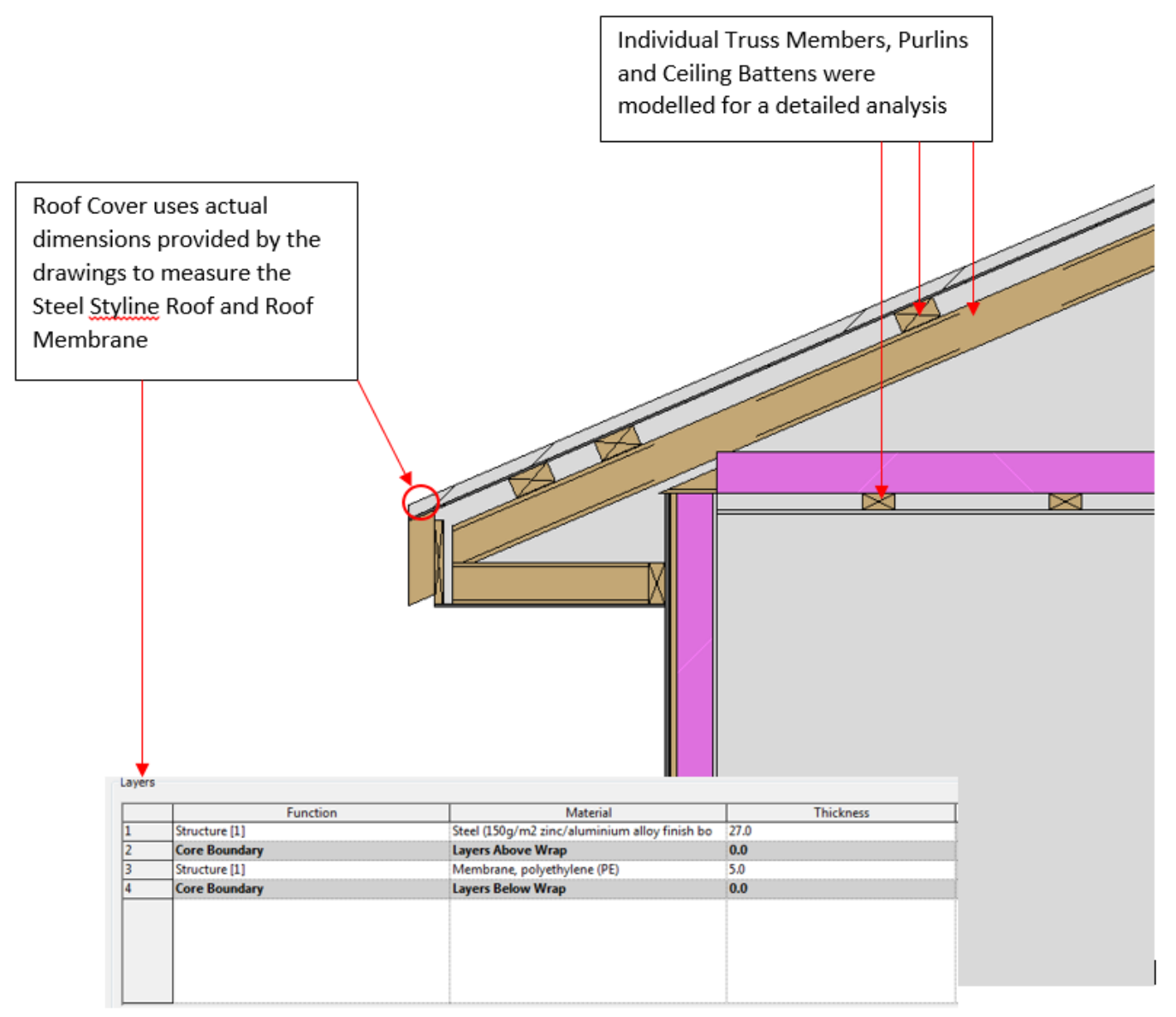

FIGURE 18: ROOF CONSTRUCTION FOR THE TEST MODEL USES A DIFFERENT PRINCIPLE IN MODELLING THAN THAT OF WALLS DUE TO A MORE DETAIL OF ELEMENTS USED IN THE CONSTRUCTION.

The Roof Cover and roof membrane are the only composite elements in the Roof Construction. They do not use a wall ratio as is already provided by the drawings what the actual dimension are. They are also a uniform element across the top of the house with no cuts or openings. 


\section{Window}

The main components of a window are that of the window frame and glazing panel (glass). Additional components that account for variables in window design are transoms and mullion. Together, these components account for the fundamental modelling components that capture the necessary information needed.

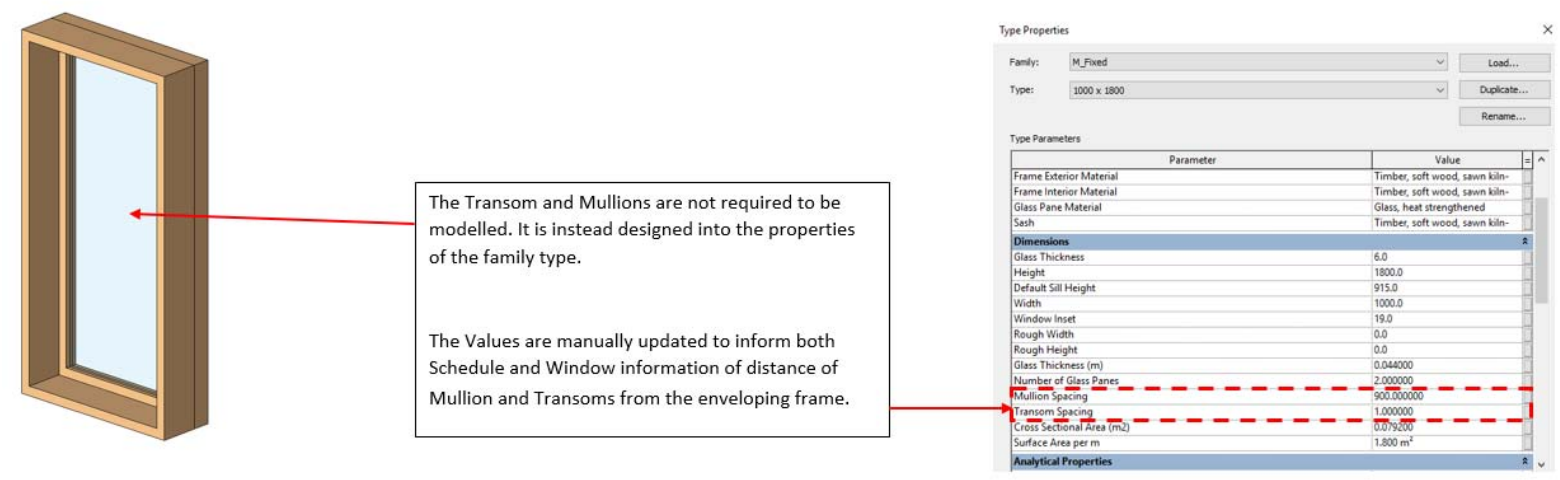

FIGURE 19: EACH MODELLED WINDOW IS REQUIRED TO MANUALLY INPUT THE COUNT OF MULLIONS AND TRANSOMS THAT WILL CALCULATED BY THE REVIT TM SCHEDULE SET FORMULAE. THIS SAVES TIME ON MODELLING.

However, in the Test model the designing of mullion and transom are further simplified and removed from the physical family component (Figure 19). Instead, they are formulas set within the Revit ${ }^{\mathrm{TM}}$ schedules. It is required to input values for the number mullions and transoms for each window separately in the instance properties of each window used in model. This way the schedules may collect the relevant information and carry the necessary calculations required.
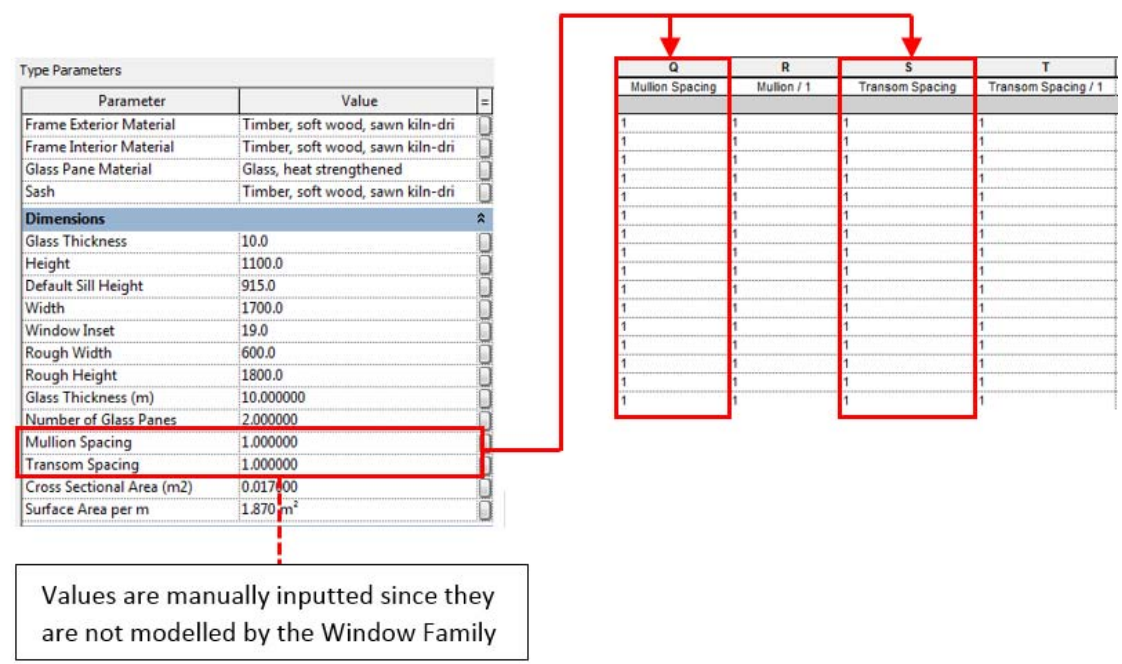

FigURE 20: THE MODELLING OF WINDOW TRANSOM AND MULLIONS ARE SUBSTITUTED WITH CALCULATIONS INSTEAD OF GEOMETRIC FORMS. 
The following table describes in detail the individual door elements that were used in the design the Test Model. Each element is unique in their variant due to their purpose in the design. They are a generic model of a door with medium level of requirement in detail.

TABle 4: The Definition of the Door Elements used in the Modelling PROcess of the Test MODEL

\begin{tabular}{|c|c|c|c|}
\hline Door Type & Image & Elements of the model & Notes \\
\hline \multirow[b]{3}{*}{$\begin{array}{l}\text { Door (General - } \\
\text { Solid Material) }\end{array}$} & & Door Panel & \multirow{3}{*}{$\begin{array}{l}\text { This Door type is the generic } \\
\text { model for all exterior and interior } \\
\text { doors. Alteration to dimensions } \\
\text { are made to suit the plans. This } \\
\text { model also includes double } \\
\text { doors }\end{array}$} \\
\hline & & Trim Interior & \\
\hline & & Trim Exterior & \\
\hline \multirow{3}{*}{$\begin{array}{l}\text { Door (General - } \\
\quad \text { Glass) }\end{array}$} & & Glass Panel & \multirow{3}{*}{$\begin{array}{l}\text { For door types that require glass } \\
\text { panels e.g. Aluminium framed } \\
\text { doors. Also designed to } \\
\text { encompass double to triple } \\
\text { panel doors. }\end{array}$} \\
\hline & & Trim Interior & \\
\hline & & Trim Exterior & \\
\hline \multirow{4}{*}{$\begin{array}{l}\text { Door (General - } \\
\text { Solid Material } \\
\text { with Side } \\
\text { Glass) }\end{array}$} & & Door Panel & \multirow{4}{*}{$\begin{array}{l}\text { Unique Doors that include the } \\
\text { use of Glass such as "Doors } \\
\text { with Sidelight" are } \\
\text { accommodated by this Door } \\
\text { Type. }\end{array}$} \\
\hline & & Glass Panel & \\
\hline & & $\begin{array}{l}\text { Door and Side Glass Trim } \\
\text { Interior }\end{array}$ & \\
\hline & & $\begin{array}{l}\text { Door and Side Glass Trim } \\
\text { Exterior }\end{array}$ & \\
\hline \multirow{3}{*}{$\begin{array}{l}\text { Door (General - } \\
\text { Sliding Internal } \\
\quad \text { Wall) }\end{array}$} & & Door Panel & \multirow{3}{*}{$\begin{array}{l}\text { For unique Doors that do not } \\
\text { swing but instead slide into wall } \\
\text { are modelled by this door type. }\end{array}$} \\
\hline & & Trim Interior & \\
\hline & & Trim Exterior & \\
\hline
\end{tabular}




\section{The Truth Model: The Formatting and Assumptions}

The Truth Model, which was the QS data, was meant to be a straightforward process of taking the raw data, format to a suitable LCAQuick format and simply simulate results (Appendix 1). However, given the extreme level of detail provided by the sheet, there were materials unable to be identified with any of the LCAQuick material coefficients, resulting in an excess of materials that could not be accounted for in the LCAQuick simulation stage (Appendix 2).

\section{Material Coefficient Placeholders}

The material library of LCAQuick does not have specific materials for some materials such as Ceramic and Plastics. This issue was resolved with a solution of using "placeholders" materials. These placeholder materials hold sufficient information to replicate the missing material but will serve simulation uses until a more suitable material information is added in the future - the placeholders will be update and removed. In the figure below are the family of materials and the placeholders that were used in each section.

TABLE 5: Placeholders designed for the House. Of the 19 FAMILIES IN THE HOUSE DESIGN, 9 FAMILIES USE PLACEHOLDERS FOR MATERIALS THAT FALL SHORT OF DATA WITHIN THE LCAQUICK MATERIAL LIBRARY (APPENDIX 2).

\begin{tabular}{|l|l|l|}
\hline Family & Placeholders Used & General Uses \\
\hline Sub Floor Timber & Carbon steel nails_Galv Steel Fixing_PLACEHOLDER & Nails \& Fixings \\
\hline Framing Hardware & Carbon steel nails_Galv Steel Fixing_PLACEHOLDER & Nails \& Fixings \\
\hline Roof Framing & Carbon steel nails_Galv Steel Fixing_PLACEHOLDER & Nails \& Fixings \\
\hline \multirow{2}{*}{$\begin{array}{l}\text { Hardie Frontier 245 I Smooth } \\
\text { W0 Weatherboards }\end{array}$} & Carbon steel nails_Galv Steel Fixing_PLACEHOLDER & Nails \& Fixings \\
\cline { 2 - 3 } & Membrane, polyvinyl chloride (PVC) & Tapes \\
\cline { 2 - 3 } & Membrane, polyethylene (PE) & Sealants \\
\hline Interior Lining & Carbon steel nails_Galv Steel Fixing_PLACEHOLDER & Nails \& Fixings \\
\hline Interior Doors & Carbon steel nails_Galv Steel Fixing_PLACEHOLDER & Nails \& Fixings \\
\hline Kitchen Fittings & Carbon steel nails_Galv Steel Fixing_PLACEHOLDER & Nails \& Fixings \\
\hline Roofing Estimate & Carbon steel nails_Galv Steel Fixing_PLACEHOLDER & Nails \& Fixings \\
\hline
\end{tabular}

Within the LCAQuick material library some material do not have the required data - as a temporary measure, the data for "Carbon steel nails" has been used as a placeholder for the materials listed in Table 5 above. The material "Carbon steel nails" holds the same data as for "Galvanised Steel sheets" in the material library. Therefore, the volume and weight of the material implies the dimensions of the material quantity, although the material coefficient may convey a higher material impact - this can result in errors of simulation.

Tapes and Sealants fall under the same condition of not having sufficient information from the LCAQuick Library. Table 5 shows that Polyvinyl Chloride (PVC) represents the masking Vinyl tapes and Polyethylene (PE) the industrial seals and tubing. It is expected in the near future that full LCE details will become available for these products.

\section{Removed Materials}

The detail at which the surveyor quantified the test houses includes small details from rubber sealants to the type of grease used on hot water cylinder piping. Again, there was insufficient data about them in the LCAQuick material library, but rather than create placeholders for these materials (Table 6), it was decided that as they would be common to both house versions (Truth and Test) there was no need to include placeholders. In addition, the environmental impact of these products are not considered 
significant enough as their LCE impact within the house design is minimal in comparison to larger elements such as timber, steel and aluminium.

\begin{tabular}{|l|l|l|l|l|}
\hline Family & Element & Material Information & $\begin{array}{l}\text { Material } \\
\text { Type }\end{array}$ & $\begin{array}{l}\text { Data } \\
\text { Validity }\end{array}$ \\
\hline \multirow{5}{*}{\begin{tabular}{c} 
Plumbin $\begin{array}{c}\text { g } \\
\text { Fittings }\end{array}$ \\
\cline { 2 - 5 }
\end{tabular}} & Vanity 1 & VENECIA 550 WBASIN WHITE W40401 & Ceramic & No data \\
\cline { 2 - 5 } & $\begin{array}{l}\text { Vlinders Pedestal } \\
\text { White }\end{array}$ & $\begin{array}{l}750 * 460 \text { PALO WHITE CENTRAL TAP } \\
\text { HOLE }\end{array}$ & Ceramic & No data \\
\cline { 2 - 5 } & Vanity Waste 1 & VANITY \& SHROUD PACK & Ceramic & No data \\
\cline { 2 - 5 } & Sink Pack 1 & PLUMBING SINK & Ceramic & No data \\
\cline { 2 - 5 } & Toilet 1 & PROFILE CC S RHSUITE TOILET 912315W & Ceramic & No data \\
\hline
\end{tabular}

TABLE 6: PLUMBING FITTINGS HAVE ELEMENTS THAT ARE OF CERAMIC NATURE. LCAQUICK LIBRARY DOES NOT HAVE ANY DATA ON CERAMIC NOR ANY DATA CLOSE ENOUGH FOR PLACEHOLDER SIMULATION. THE ELEMENTS HAVE SINCE BEEN OMITTED FROM THE HOUSE TESTING STAGES. 


\section{Chapter 5: Results Assessment and Discussion}

Chapter 5 involves the assessment of the testing phase, which involved the investigation of material analysis on the selected House. The process involved the separate testing of a Quantity Surveyor data and Revit ${ }^{\mathrm{TM}}$ model with the goal of understanding how close the model results were. The results are presented in this chapter as two separate analysis sections, the Truth Model Results (QS Data) and the Test Model Results (Revit ${ }^{\mathrm{TM}}$ model Data).

The Chapter analyses the results, clarifies any errors that may be a result of assumptions. Then, the side-by-side comparison of the two models can take place with the discussion critically analysing any differences. The accuracy of the result will be further explored and any remaining questions will be discussed in later chapters.

The following tables provide not the material quantities used as input to LCAQuick, but the output of Total Primary Energy (TPE). This has been calculated using the formula given in Chapter 2:

\section{"Quantities of Materials x Material Environmental Coefficients = Environmental Impact"}

In analysing both of the models, the "placeholder" values have been removed. In both models, while still following the LOD 350 guideline, the detail of door fascia or doorknobs where not modelled. Instead, a generic assembly was modelled. Similar choices were made for other Building Families models.

\section{Truth Model Results}

Table 7 illustrates the environmental energy impact of the Building (Component) Families in the Truth Model. The first numerical column gives the TPE output from LCAQuick, while the second column shows the proportion for that Building Family of the overall TPE. The third column is based on the assumption that a maximum of $10 \%$ difference between the two models is desirable while the forth column gives the absolute TPE value for that Building Family. Thus while the sub-floor accounts for $940.42 \mathrm{MJ}$ and $23 \%$ of the overall TPE, the variation permitted (assuming a 10\% overall difference) would be $94.04 \mathrm{MJ}$

TABLE 7: TRUTH MOdEL SiMULATION RESULtS

\begin{tabular}{|c|c|c|c|c|}
\hline Building Component Family & $\begin{array}{c}\text { Total } \\
\text { Primary } \\
\text { Energy MJ }\end{array}$ & $\begin{array}{c}\text { Element's \% } \\
\text { of Total } \\
\text { Environmental } \\
\text { Impact }\end{array}$ & $\begin{array}{c}\text { Element's } \\
\text { Proportion of } \\
\text { Whole } \\
\text { Building's } \\
\text { Margin of Error }\end{array}$ & $\begin{array}{c}\text { Maximum } \\
\text { allowable } \\
\text { size of } \\
\text { error (TPE } \\
\text { MJ) } \\
\end{array}$ \\
\hline Sub Floor & 940.42 & $23 \%$ & $2.29 \%$ & 94.04 \\
\hline Ceiling Framing & 138.11 & $3 \%$ & $0.34 \%$ & 13.81 \\
\hline Roof Framing & 176.67 & $4 \%$ & $0.43 \%$ & 17.67 \\
\hline Soffit - Fascia & 70.46 & $2 \%$ & $0.17 \%$ & 7.05 \\
\hline $\begin{array}{l}\text { Roofing Estimate Roof Total Lineal } \\
\text { Meters }\end{array}$ & 184.76 & $4 \%$ & $0.45 \%$ & 18.48 \\
\hline Aluminium Framing Materials (Total) & 1513.81 & $37 \%$ & $3.69 \%$ & 151.38 \\
\hline Window and Door (Glass Material) & 72.01 & $2 \%$ & $0.18 \%$ & 7.20 \\
\hline Exterior Wall Timber Use (Total) & 469.87 & $11 \%$ & $1.14 \%$ & 46.99 \\
\hline Insulation & 168.48 & $4 \%$ & $0.41 \%$ & 16.85 \\
\hline Weatherboards & 190.29 & $5 \%$ & $0.46 \%$ & 19.03 \\
\hline Interior Walls & 102.89 & $3 \%$ & $0.25 \%$ & 10.29 \\
\hline Doors & 78.51 & $2 \%$ & $0.19 \%$ & 7.85 \\
\hline Total & 4106.27 & $100.00 \%$ & & \\
\hline
\end{tabular}




\section{Truth Model - Building Families}

Table 7 is a summary of the results from the Truth Model LCAQuick Simulation. As shown in Table 7, each Building Component contributes varying levels of environmental impact. However, due to the complexity of the categories, clarifications on the list of building elements need to be made. This is to allow for an open view of what was tested and where the results of the impact stem from. To say that a "Sub Floor" alone contributes an impact of " $940.42 \mathrm{MJ}$ " is only a general view of what lies behind the scenes. A more detailed description would deliver an informative insight to these hidden factors, therefore, below are the sub elements that were categorised within these Building Families. This is provided in Table 8.

\section{TABLE 8: TRUTH MODEL MATERIAL COMPOSITION}

\begin{tabular}{|l|l|}
\hline \multicolumn{2}{|l|}{ Building Family - Materials } \\
\hline \multirow{2}{*}{ Sub Floor } & Timber, soft wood, sawn kiln-dried sections \\
\cline { 2 - 2 } & Concrete, 17.5 MPa, in-situ, no reinforcement, (OPC) \\
\hline Ceiling Framing & Timber, soft wood, sawn kiln-dried sections \\
\hline Roof Framing & Timber, soft wood, sawn kiln-dried sections \\
\hline \multirow{2}{*}{ Soffit - Fascia } & Timber, soft wood, sawn kiln-dried sections \\
\cline { 2 - 2 } & Fibre cement boards \\
\hline \multirow{2}{*}{ Roof Cover } & $\begin{array}{l}\text { Steel (galvanised finish, both sides, 0.02 mm each), profile metal } \\
\text { sheet, 28mm trapezoidal profile, 0.4mm BMT }\end{array}$ \\
\hline Aluminium Total & Aluminium (anodised, one side 0.02 mm), profile sheet metal, \\
\hline Glass & Glass, heat strengthened \\
\hline Exterior Wall Timber Use & Timber, soft wood, sawn kiln-dried sections \\
\hline \multirow{2}{*}{ Insulation } & Insulation, Glass Wool \\
\cline { 2 - 2 } & Insulation, polystyrene expanded (EPS) \\
\hline Weatherboards & Fibre cement boards \\
\hline Interior Walls & Gypsum plasterboard \\
\hline Doors & Timber, soft wood, sawn kiln-dried sections \\
\hline
\end{tabular}

Thus it can be seen from Table 8 that the sub-floor comprises timber and concrete. Table 9 provides a more detailed analysis of the materials by order of the highest impact in Table 7. A similar table is provided later (Table 12) for the Test Model. 


\begin{tabular}{|c|c|c|}
\hline & $\begin{array}{l}\text { Aluminium } \\
\text { Framing } \\
\text { Materials }\end{array}$ & $\begin{array}{l}\text { The highest impacting element noted within the summary is Aluminium } \\
\text { Framing Materials. A key note would to explain that the data input into the } \\
\text { simulation was the raw take from the QS sheet. It does not specify } \\
\text { specifically the dimensions of the member of aluminium or the allocation of } \\
\text { these Aluminium members within the house drawings. In the case of the } \\
\text { Revit }{ }^{\mathrm{TM}} \text { model, all aluminium was allocated to the only elements that were } \\
\text { shown by the drawings to have consisted aluminium in composition. }\end{array}$ \\
\hline & Sub-Floor & $\begin{array}{l}\text { The Sub Floor comprises of a significant chunk of the house composition, } \\
\text { from the floor to the earth level. This covers the significant amount of timer } \\
\text { use used bit the house for foundation stability. This covers floor Joists, } \\
\text { Timber Piles and Cover boards, which consolidates the majority of the } \\
\text { timber use. The data reflects this along with the addition of concrete for } \\
\text { each timber pile. }\end{array}$ \\
\hline & $\begin{array}{l}\text { Ceiling } \\
\text { Framing }\end{array}$ & $\begin{array}{l}\text { Uniquely isolated for the sake of a detailed level of analysis, the Ceiling } \\
\text { Framing is set apart from Roof Framing. This is to avoid a total overall } \\
\text { account of materials from Ceiling level upwards towards the Roof thus } \\
\text { avoiding a more detailed analysis of both elements as separate. Hence, } \\
\text { Ceiling Framing and Roof Framing are set apart. } \\
\text { The Ceiling Lining was not included in the Data and could be a result of } \\
\text { Input error. The Ceiling Lining is allocated in the Material Proxys instead - } \\
\text { an error that needs to be fixed. }\end{array}$ \\
\hline & $\begin{array}{l}\text { Exterior Wall } \\
\text { Timber Use }\end{array}$ & $\begin{array}{l}\text { Exterior Wall Timber Use account for the majority of elements that comprise } \\
\text { the housing envelope materials. These include the Stud Framing, Top and } \\
\text { Bottom Plate, Wall Battens, and Window and Door Lintels. Framing Ratio } \\
\text { used is } 20 \% \text {. }\end{array}$ \\
\hline & Roof Framing & Roof Faming consist of Framing Purlins, Fly Rafters, and Trusses \\
\hline & Insulation & Insulation accounts for all insulation in the floor, walls, and ceiling. \\
\hline & Interior Walls & $\begin{array}{l}\text { Interior wall as noted within the drawings consist of an empty cavity and } \\
\text { have no simulation. There are also not many walls in the house design. }\end{array}$ \\
\hline & Doors & $\begin{array}{l}\text { Doors mainly use internal void timber panels and there are } 13 \text { of them in } \\
\text { the house design. These are mostly interior doors as the exterior doors use } \\
\text { aluminium framed triple panel doors (sliding). }\end{array}$ \\
\hline & $\begin{array}{l}\text { Window and } \\
\text { Door (Glass } \\
\text { Material) }\end{array}$ & $\begin{array}{l}\text { The Window and Door (Glass Material) relate to the window glass panels } \\
\text { as well as the glass panels used in the Aluminium framed doors. }\end{array}$ \\
\hline & $\begin{array}{l}\text { Soffit and } \\
\text { Fascia }\end{array}$ & $\begin{array}{l}\text { As in a unique case for this QS model, the Soffit and Fascia are classified } \\
\text { separately away from Roof Framing family as the Revit }{ }^{\mathrm{TM}} \text { model had to } \\
\text { model this separately and for the sake of a consistent side by side } \\
\text { comparison, the QS model was then made to isolate its own. It is the } \\
\text { smallest in QS impact as they are strips of timber members that encase the } \\
\text { top rim of the house design. }\end{array}$ \\
\hline & Weatherboards & $\begin{array}{l}\text { The Weatherboards use Fibre cement material and classify separately from } \\
\text { the Exterior Wall Timber Use (Total). }\end{array}$ \\
\hline & Interior Walls & $\begin{array}{l}\text { The Interior walls have no insulation and comprise only of timber studs with } \\
\text { Timber board covering. }\end{array}$ \\
\hline & Doors & $\begin{array}{l}\text { The Doors are internal void timber panels and there are } 13 \text { of them in the } \\
\text { house design. }\end{array}$ \\
\hline
\end{tabular}

\section{Test Model Results}

The summary of the results for the Test Model house is given in Table 10, following the same format as for Table 7. Thus while the sub-floor accounts for $827.83 \mathrm{MJ}$ (Truth Model $940.42 \mathrm{MJ}$ ) and $27 \%$ (Truth Model 23\%) of the overall TPE, 10\% variation is $92.78 \mathrm{MJ}$ (Truth Model 94.04 $\mathrm{MJ})$ 
TABle 10: Test Model Results

\begin{tabular}{|c|c|c|c|c|}
\hline Building Families & $\begin{array}{l}\text { Total } \\
\text { Primary } \\
\text { Energy MJ }\end{array}$ & $\begin{array}{l}\text { Element's \% } \\
\text { of Total } \\
\text { Environmental } \\
\text { Impact }\end{array}$ & $\begin{array}{l}\text { Element's } \\
\text { Proportion } \\
\text { of Whole } \\
\text { Building's } \\
\text { Margin of } \\
\text { Error }\end{array}$ & $\begin{array}{l}\text { Maximum } \\
\text { allowable } \\
\text { size of } \\
\text { error } \\
\text { (TPE MJ) }\end{array}$ \\
\hline Sub Floor & 927.83 & $27 \%$ & $2.70 \%$ & 92.78 \\
\hline Ceiling Framing & 138.02 & $4 \%$ & $0.40 \%$ & 13.80 \\
\hline Roof Framing & 305.06 & $9 \%$ & $0.89 \%$ & 30.51 \\
\hline Soffit - Fascia & 45.35 & $1 \%$ & $0.13 \%$ & 4.54 \\
\hline $\begin{array}{l}\text { Roofing Estimate Roof Total Lineal } \\
\text { Meters }\end{array}$ & 156.10 & $5 \%$ & $0.45 \%$ & 15.61 \\
\hline Aluminium Framing Materials (Total) & 884.57 & $26 \%$ & $2.57 \%$ & 88.46 \\
\hline Window and Door (Glass Material) & 139.37 & $4 \%$ & $0.41 \%$ & 13.94 \\
\hline Exterior Wall Materials & 367.96 & $11 \%$ & $1.07 \%$ & 36.80 \\
\hline Insulation & 139.54 & $4 \%$ & $0.41 \%$ & 13.95 \\
\hline Weatherboards & 135.51 & $4 \%$ & $0.39 \%$ & 13.55 \\
\hline Interior Walls & 74.24 & $2 \%$ & $0.22 \%$ & 7.42 \\
\hline Doors & 126.75 & $4 \%$ & $0.37 \%$ & 12.67 \\
\hline Total & 3440.31 & $100.00 \%$ & & \\
\hline Whole Building Margin of Error (10\%) & 344.03 & & $10.00 \%$ & 344.03 \\
\hline
\end{tabular}

Test Model - Building Families

Similar to the Truth Model Building Families, each Building Family contributes to varying levels of environmental impact to the Test Model. Table 11 below gives the sub elements that were categorised within these Building Families.

\section{TABLE 11: Test Model MATERIAL Composition}

\begin{tabular}{|l|l|}
\hline \multirow{2}{*}{ Sub Floor } & Timber, soft wood, sawn kiln-dried sections \\
\cline { 2 - 2 } & Concrete, 17.5 MPa, in-situ, no reinforcement, (OPC) \\
\hline Ceiling Framing & Timber, soft wood, sawn kiln-dried sections \\
\hline Roof Framing & Timber, soft wood, sawn kiln-dried sections \\
\hline \multirow{2}{*}{ Soffit - Fascia } & Timber, soft wood, sawn kiln-dried sections \\
\cline { 2 - 2 } $\begin{array}{l}\text { Roofing Estimate Roof Total } \\
\text { Lineal Meters }\end{array}$ & $\begin{array}{l}\text { Steel (150g/m2 zinc/aluminium alloy finish both sides), profile metal } \\
\text { sheet, generic all profiles, 0.4mm BMT }\end{array}$ \\
\hline \multirow{2}{*}{$\begin{array}{l}\text { Aluminium Framing Materials } \\
\text { (Total) }\end{array}$} & $\begin{array}{l}\text { Aluminium (powder coated finish, one side 0.08 mm), extruded glazing } \\
\text { frame, 2.0mm BMT }\end{array}$ \\
\cline { 2 - 2 } $\begin{array}{l}\text { Window and Door (Glass } \\
\text { Material) }\end{array}$ & Glass, heat strengthened \\
\hline Exterior Wall Timber Use (Total) & Glass, heat strengthened \\
\hline \multirow{2}{*}{ Insulation } & Insulation, Glass Wool \\
\cline { 2 - 2 } & Insulation, polystyrene expanded (EPS) \\
\hline Weatherboards & Fibre cement boards \\
\hline Interior Walls & Gypsum plasterboard \\
\hline Doors & Timber, soft wood, sawn kiln-dried sections \\
\hline
\end{tabular}


Test Model - Analysis of Materials

Table 12 provides a more detailed analysis of the materials by order of the highest impact in Table 10. A similar table was provided earlier (Table 9) for the Test Model.

TABLE 12: TeSt MODEL - INDIVIDUAL MATERIAL DEFINITION

\begin{tabular}{|c|c|}
\hline $\begin{array}{l}\text { 1. Aluminium Framing } \\
\text { Materials (Total) }\end{array}$ & $\begin{array}{l}\text { The Aluminium Framing Materials accounted for in the Revit }{ }^{\mathrm{TM}} \text { model } \\
\text { correspond to all Exterior Window and Door Frames that use aluminium as } \\
\text { framing materials. This was modelled in accordance with the drawings } \\
\text { whereas the QS model took the sample of Aluminium Framing as a total. }\end{array}$ \\
\hline 2. Sub Floor & $\begin{array}{l}\text { Following the Aluminium impact contribution, the sub floor is the second } \\
\text { highest contributor of impact as this would consist of the numerous timber } \\
\text { members that serve as the foundation. This includes the foundation piles, floor } \\
\text { joists, and cover boards that surround the foundation from exposure. The } \\
\text { concrete in the Revit } \\
\text { of timber pile used. }\end{array}$ \\
\hline $\begin{array}{l}\text { 3. Ceiling Framing } \\
\text { (Battens) }\end{array}$ & $\begin{array}{l}\text { The Ceiling framing which accounts only for the ceiling battens indicate } \\
\text { consists of the same error as the QS data that the Ceiling Lining was not } \\
\text { included in the calculation. This is an error as the value only indicates the } \\
\text { impacts of the Battens alone in the ceiling. }\end{array}$ \\
\hline $\begin{array}{l}\text { 4. Roof Framing } \\
\text { (Purlins) }\end{array}$ & $\begin{array}{l}\text { Roof Framing accounts for the timber truss frames that comprise the } \\
\text { structural integrity of the roof. This includes the Purlins as well. }\end{array}$ \\
\hline 5. Soffit - Fascia & $\begin{array}{l}\text { The soffit and fascia are lengthy members that wrap the top exterior of the } \\
\text { house. They comprise of Timber Material only. }\end{array}$ \\
\hline $\begin{array}{l}\text { 6. Roofing Estimate } \\
\text { Roof Total Lineal } \\
\text { Meters }\end{array}$ & $\begin{array}{l}\text { This is the isolated roof sheet cover. For the ideal comparison of materials, the } \\
\text { roof sheet cover is of a Steel material and had to be isolated to understand the } \\
\text { unique impact contribution that the material itself delivered. }\end{array}$ \\
\hline $\begin{array}{l}\text { 7. Window and Door } \\
\text { (Glass Material) }\end{array}$ & The Glass Panels of the windows and doors are only accounted for here. \\
\hline $\begin{array}{l}\text { 8. Exterior Wall } \\
\text { Timber Use (Total) }\end{array}$ & $\begin{array}{l}\text { The Exterior Timber wall use, as similar to the test model, accounts for all } \\
\text { Timber material used in the house envelop construction. From the timber } \\
\text { studs, Door and Window Lintels, and Top and Bottom Plates. }\end{array}$ \\
\hline 9. Insulation & $\begin{array}{l}\text { All the insulation accounted for include the insulation in the Floor, Walls and } \\
\text { Ceiling. }\end{array}$ \\
\hline 10. Weatherboards & $\begin{array}{l}\text { The Weatherboards use Fibre cement material and classify separately from the } \\
\text { Exterior Wall Timber Use (Total). }\end{array}$ \\
\hline 11. Interior Walls & $\begin{array}{l}\text { The Interior walls have no insulation and comprise only of timber studs with } \\
\text { Timber board covering. }\end{array}$ \\
\hline 12. Doors & $\begin{array}{l}\text { The Doors are internal void timber panels and there are } 13 \text { of them in the } \\
\text { house design. }\end{array}$ \\
\hline
\end{tabular}

\section{The Methodology of Comparison}

The analysis compares both the material volume inputs and TPE outputs of the Truth and Test models, at both a Building Family and Total level. From here, the errors need to be analysed further as to flesh out the testing methodology.
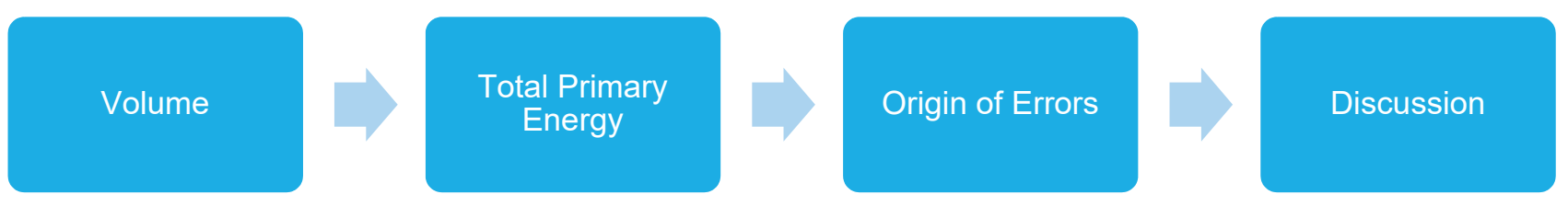

FiguRE 21: The MEthodology of Results ANALysis 


\section{Volume Comparison}

The "Roofing Estimate: Roof Total Lineal Meters" has been ignored for this analysis for both models. This is due to the nature of the material, which has a corrugated surface that demands the calculation method within the LCAQuick tool analysis that requires area input in $\mathrm{m}^{2}$ rather than volume $\mathrm{m}^{3}$.

TABle 13: TRuth Model Vs Test model Volume Comparison

\begin{tabular}{|l|r|r|r|r|l|}
\hline \multicolumn{1}{|c|}{ Building Family } & $\begin{array}{c}\text { Truth Model } \\
\text { Volume }\end{array}$ & $\begin{array}{c}\text { Test Model } \\
\text { Volume }\end{array}$ & $\begin{array}{c}\text { Volume } \\
\text { Difference }\end{array}$ & \multicolumn{1}{c|}{$\begin{array}{l}\text { Volume \% } \\
\text { Difference }\end{array}$} & \multicolumn{1}{c|}{ Threshold } \\
\hline Sub Floor & 8.98 & 9.93 & -0.95 & -10.64 & Safe \\
\hline Ceiling Framing & 1.78 & 1.774 & 0.00 & 0.15 & Safe \\
\hline Roof Framing & 1.42 & 2.455 & -1.03 & -72.68 & Extreme \\
\hline Soffit - Fascia & 0.47 & 0.301 & 0.17 & 35.62 & Reasonable \\
\hline $\begin{array}{l}\text { Roofing Estimate Roof Total } \\
\text { Lineal Meters }\end{array}$ & 4.26 & 4.26 & 0.00 & 0 & Null \\
\hline Aluminum Framing Materials (Total) & 0.50 & 0.302 & 0.20 & 39.25 & Reasonable \\
\hline Window and Door (Glass Material) & 0.21 & 0.412 & -0.20 & -93.54 & Extreme \\
\hline Exterior Wall Timber Use (Total) & 3.78 & 3.718 & 0.06 & 1.68 & Reasonable \\
\hline Insulation & 25.39 & 21.751 & 3.64 & 14.33 & Reasonable \\
\hline Weatherboards & 0.93 & 0.665 & 0.27 & 28.79 & Reasonable \\
\hline Interior Walls & 2.03 & 1.465 & 0.57 & 27.85 & Reasonable \\
\hline Doors & 0.63 & 1.02 & -0.39 & -61.45 & Extreme \\
\hline TOTAL & $\mathbf{4 6 . 1 2}$ & $\mathbf{4 3 . 7 9}$ & $\mathbf{2 . 3 3}$ & & \\
\hline
\end{tabular}

Table 13 shows the total reported volume for the Truth Model is $46.12 \mathrm{~m}^{3}$ and for the Test Model $43.79 \mathrm{~m}^{3}$ - a difference of $2.33 \mathrm{~m}^{3}$ or $5 \%$, well within the goal of $10 \%$. However, Table 13 also shows that only two Building Families are within a $\pm 10 \%$ difference, shown in the rightmost column as green. These are the "Ceiling framing" (3\% of the total environmental impact) and the "Exterior Wall Timber Use (Total)" (11\%), which together are $14 \%$ of total environmental impact of the Truth Model.

This is quite daunting, as the remaining $86 \%$ of the Truth Model differs by quite a large percentage values. However, a more detailed look into the data yields deeper understanding of these differences. Taking an average of the smaller errors from the table shows a difference range $40.0 \%$ to $10.0 \%$. This will be called the "Reasonable" threshold for the modelling differences, and is shown in the rightmost column as blue.

- $\quad$ Soffit - Fascia - 35.62\%

- Aluminium Framing Material (Total) $-39.62 \%$

- Insulation $-14.33 \%$

- Weatherboard $-28.79 \%$

- Interior Walls - $27.85 \%$

However, the remaining data that exceed this "Reasonable" threshold can be considered as the "Extreme" threshold, which is shown in the rightmost colour as red.

- Roof Framing - (-72.68)

- Window and Door (Glass Material) - (-93.54)

- Door - (-61.45) 


\section{Volume Percentage Difference}

The Volume Percentage Difference graph (Figure 22) is an indication of which part of the models is the most important in terms of difference based on cubic metres of material. The positive values indicate that the Truth Model outweighs the Test Model in comparison, whereas the negative values would indicate the opposite of Test over Truth. It can be seen that the Roof Framing, Window and Door (Glass Material) and Doors have an excess of materials in modelling over than what the QS data had measured out. Since by default, the general idea is that the Test must meet Truth where the positive values range above, the negative values portray some keen points of interest in the same manner as well.

Points of Interest - Volume outweigh (Test vs Truth)

- Roof Framing

- Window and Door (Glass Material)

- Doors

These points of interest are also found in the "Extreme" threshold of margin difference as seen in the "Threshold Volume Percentage Difference Graph" (Figure 23). 



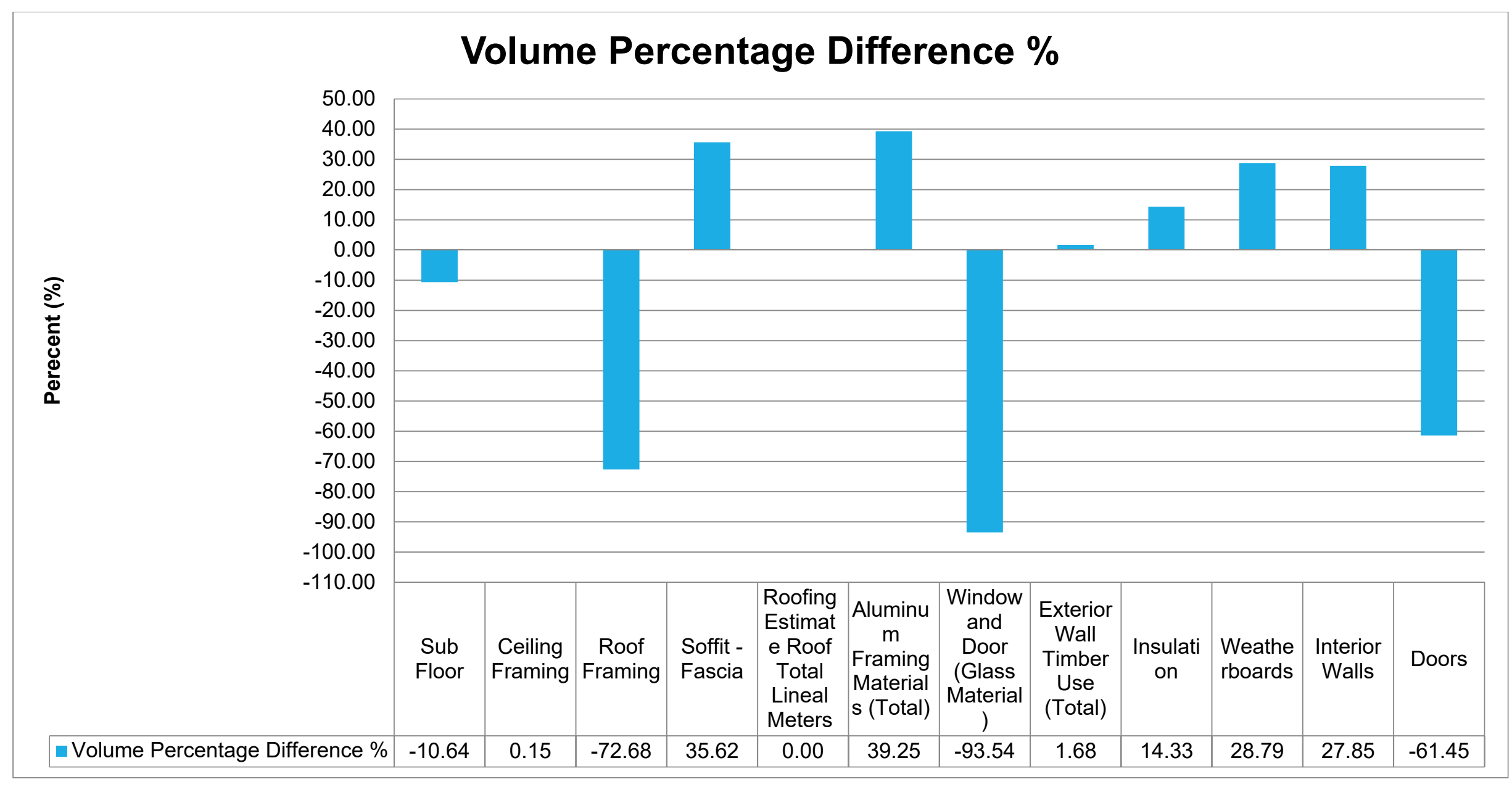

Figure 22: Volume Percentage Difference between the Truth Model AND Test Model 


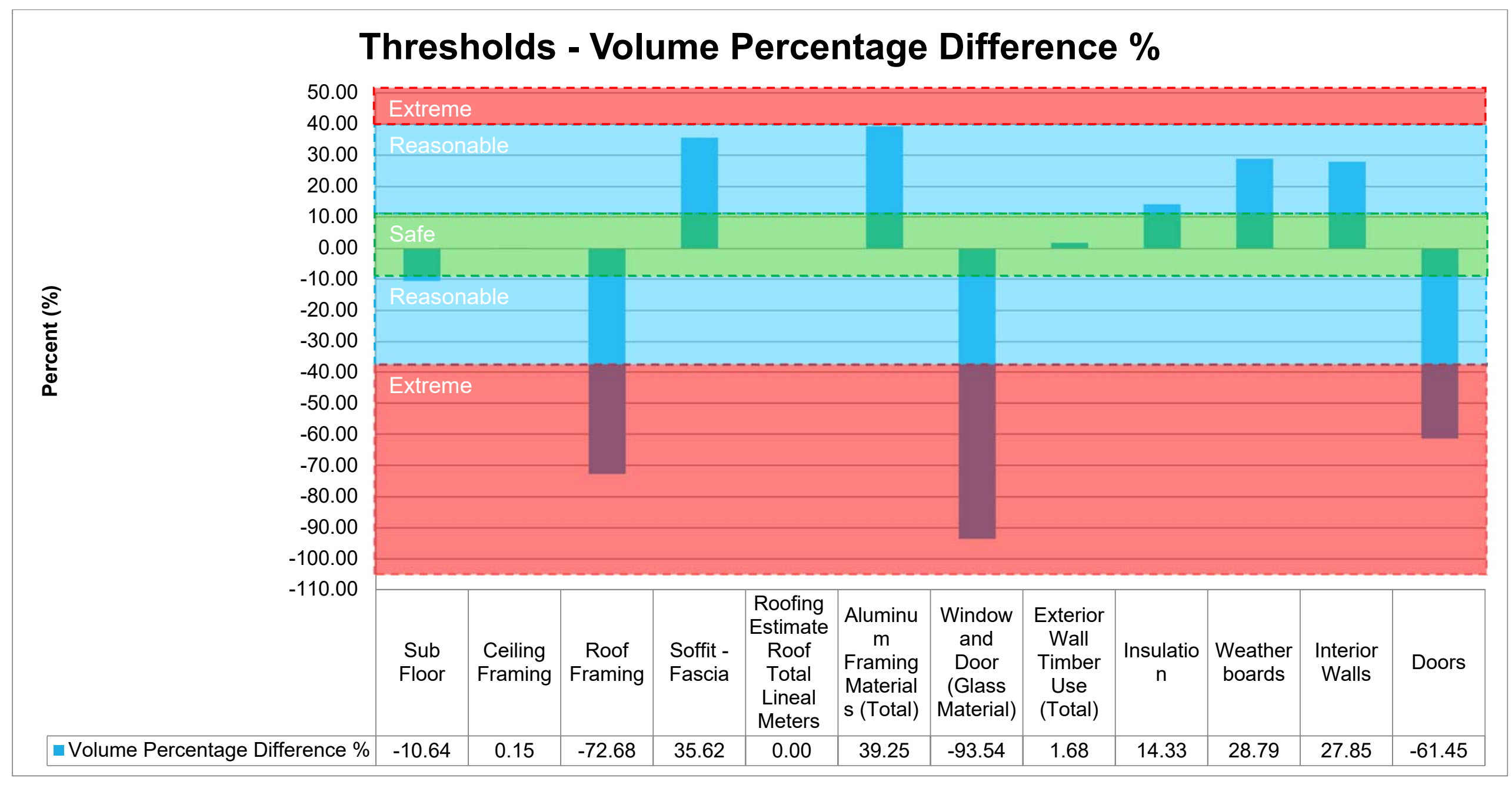

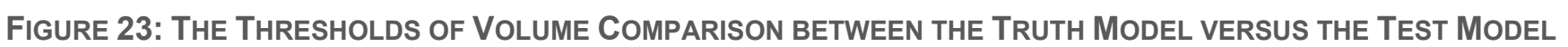




\section{The Total Primary Energy Comparison: Truth Model vs Test Model:}

Table 14 compares the TPE for the two models. It can be seen from the side-by-side comparison that though some of the Test model Building Families are less than their Truth Model counterparts, there are notable large differences. Roof Framing, Aluminium Framing, Window and Door (Glass Material), Exterior Wall Timber Use (Total) and Doors.

Table 14 also gives the difference between the two TPE models as percentages to which of the Building Families reach the acceptable error margin, as well as any anomalies. The same five Building Families that show as reasonable in the Volume table (Table 13) also show in the Total Primary Energy table (Table 14), as do the two extremes.

Table 14: The Total Primary Energy Comparison between The Truth Model Versus the TEST MODEL

\begin{tabular}{|l|r|r|r|r|}
\hline Building Family & $\begin{array}{l}\text { TPE Truth } \\
\text { Model (GJ) }\end{array}$ & $\begin{array}{l}\text { TPE Test } \\
\text { Model (GJ) }\end{array}$ & $\begin{array}{l}\text { TPE } \\
\text { Difference } \\
\text { (GJ) }\end{array}$ & $\begin{array}{l}\text { TPE \% } \\
\text { Difference }\end{array}$ \\
\hline Sub Floor & 0.94 & 0.93 & 12.59 & 1.34 \\
\hline Ceiling Framing & 0.14 & 0.14 & 0.08 & 0.06 \\
\hline Roof Framing & 0.18 & 0.31 & -128.40 & -72.68 \\
\hline Soffit - Fascia & 0.07 & 0.05 & 25.11 & 35.63 \\
\hline Roofing Estimate Roof Total Lineal Meters & 0.18 & 0.16 & 28.65 & 15.51 \\
\hline Aluminum Framing Materials (Total) & 1.51 & 0.88 & 629.24 & 41.57 \\
\hline Window and Door (Glass Material) & 0.07 & 0.14 & -67.36 & -93.54 \\
\hline Exterior Wall Timber Use (Total) & 0.47 & 0.37 & 101.92 & 21.69 \\
\hline Insulation & 0.17 & 0.14 & 28.94 & 17.17 \\
\hline Weatherboards & 0.19 & 0.14 & 54.78 & 28.79 \\
\hline Interior Walls & 0.10 & 0.07 & 28.65 & 27.85 \\
\hline Doors & 0.08 & 0.13 & -48.24 & -61.45 \\
\hline
\end{tabular}

Table 13 and Table 14 both show the Test Model has Building Families with higher impacts (both volume and TPE) than the Truth model. This was not expected - it was thought that the Test Model would have more elements of impact, as the Test Model is expected to aspire to Truth Model in design and not exceed it. The purpose of this research is to see how close a user can model to the test model to replicate an effective virtual example i.e. Truth Model. However, in the case of these five material groups, the error has been documented during the testing period and shall be explained. 

Total Primary Energy MJ Comparison

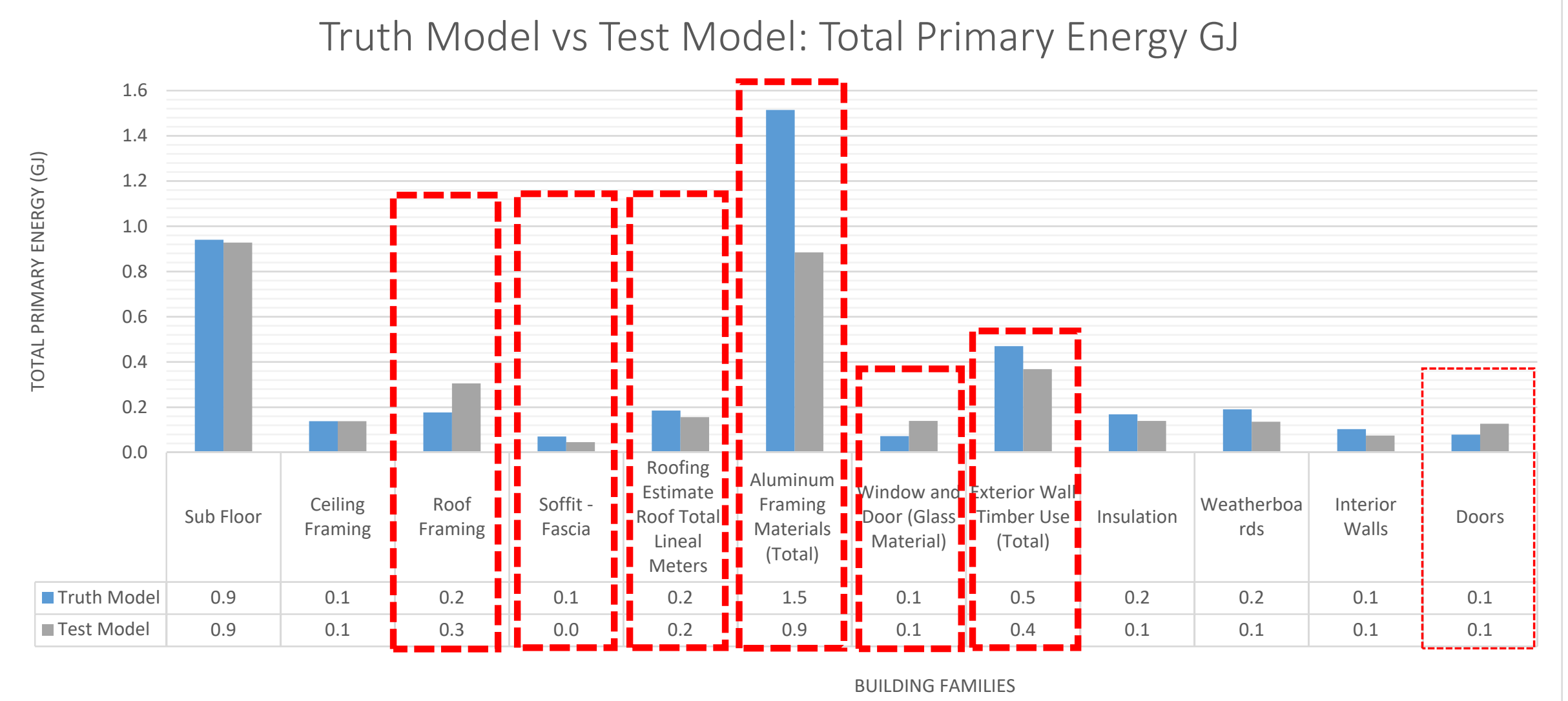

Figure 24: Truth Model vs Test Model: Total Primary energy MJ 
Percentage Difference: Truth Mode vs Test Model

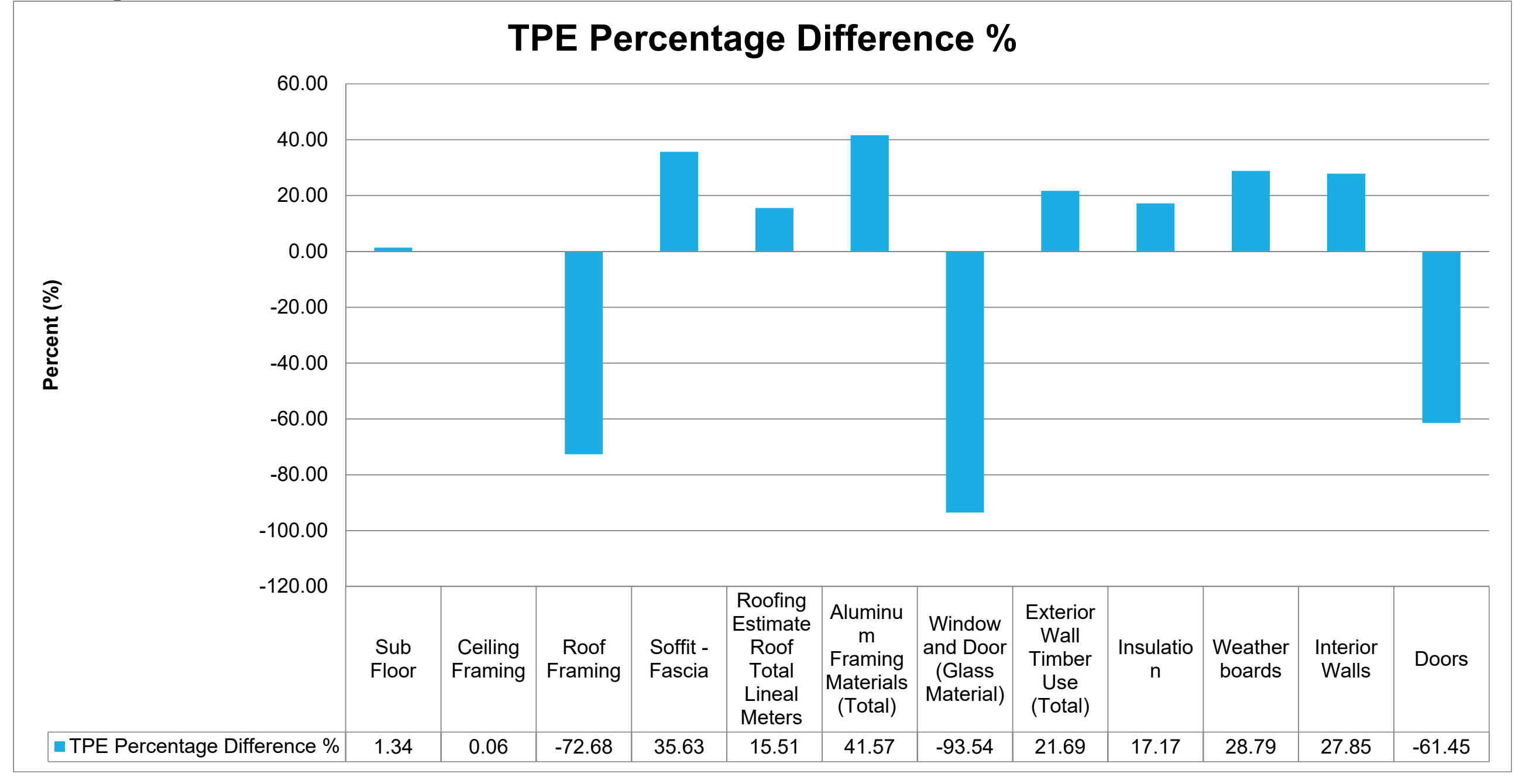

Figure 25: The Total Primary Percentage Difference between the Truth Model and Test Model 


\section{Origin of Differences}

The Origin of differences returns to the raw data of both models to identify the difference between the Test and Truth models. From the Volume comparison and the Total Primary energy Comparison, it was clear that that the Test Model over exceeded the Truth Model in the following areas:

- Aluminium Framing (Materials)

- Roof Framing (Materials)

- Window and Door (Glass Material)

- Doors (Panel)

This part of the analysis is examines the raw data to identifying if it is a user error due to a data input mistake entry or as a result of multiple assumptions.

\section{Aluminium Framing (Materials)}

The complicated issue of the Aluminium input data has shown significant difference. This is possibly due to the QS data specification of what "members of aluminium" were used and which family members they were allocated to e.g. window or door.

\section{TABLE 15: TRUTH Model Aluminium FRAMing SCHEdULE EXCERPT}

\begin{tabular}{|l|l|r|}
\hline Family & Material Name & $\begin{array}{l}\text { Volume } \\
\left(\mathbf{m}^{3}\right)\end{array}$ \\
\hline Aluminium support bar for windowsWindow C6/F6/G6IJ6IL6/M6/R6 & LINTEL 190*45*705 H1.2 & 0.012 \\
\hline $\begin{array}{l}\text { (Door) - Aluminium support bar for windowsWindow V9/Z9/Z9WZ9-SR9 } \\
\text { 2/R12-2 }\end{array}$ & (Door) LINTEL 190*45*985 H1.2 & 0.008 \\
\hline Aluminium support bar for windowsWindow G16/J161T16/X16 & LINTEL 190*45*1305 H1.2 & 0.001 \\
\hline $\begin{array}{l}\text { (Door) - Aluminium support bar for windowsWindow } \\
\text { C24IG24/L241Y241Y24W/U24IU2 }\end{array}$ & LINTEL 190*45*1705 H1.2 & 0.029 \\
\hline $\begin{array}{l}\text { (Door) - Aluminium support bar for windowsWindow Y281U28 } \\
\text { Aluminium support bar for windowsWindow C6IF6/G6IJ6IL6/M6/R6 }\end{array}$ & (Door) LINTEL 190*45*2505*2 H1.2 & 0.043 \\
\hline $\begin{array}{l}\text { Aluminium support bar for windowsWindow C12-2IG12-2/J12-2IM12- } \\
\text { 21R12-2 }\end{array}$ & LINTEL 190*45*705 H1.2 & 0.125 \\
\hline Aluminium support bar for windowsWindow G16/J161T161X16 & LINTEL 190*45*1705 H1.2 & 0.006 \\
\hline Aluminium frame for windowsWindow C6/F6/G6IJ6IL6/M6/R6 & LINTEL 190*45*705 H1.2 & 0.011 \\
\hline $\begin{array}{l}\text { (Door) - Aluminium frame for windowsWindow V9/Z9/Z9WZ9-SR9 } \\
\text { Aluminium frame for windowsWindow C12-2IG12-2IJ12-2/M12-2/R12-2 }\end{array}$ & (Door) LINTEL 190*45*985 H1.2 & 0.015 \\
\hline Aluminium frame for windowsWindow G16/J161T16/X16 & LINTEL 190*45*1705 H1.2 & 0.012 \\
\hline $\begin{array}{l}\text { (Door) - Aluminium frame for windowsWindow } \\
\text { C24IG24/L241Y241Y24W/U24IU2 }\end{array}$ & 0.008 \\
\hline \begin{tabular}{l} 
(Door) - Aluminium frame for windowsWindow Y281U28 \\
\hline Aluminium frame for windowsWindow C6IF6/G6IJ6IL6/M6/R6
\end{tabular} & (Door) LINTEL 190*45*2505*2 H1.2 & 0.011 \\
\hline Aluminium frame for windowsWindow C12-2IG12-2/J12-2IM12-21R12-2 & LINTEL 190*45*1305 H1.2 & 0.029 \\
\hline $\begin{array}{l}\text { (Door) LINTEL 240*45*2905*2 H1.2 } \\
\text { TOTAL }\end{array}$ & 0.043 \\
\hline
\end{tabular}

The second column (Material Names) in Table 15 gives the naming convention used by the QS. For example, "Lintel 190*45*705 H1.2.0" was used across all fields of the Aluminium Framing members of QS data sheet. Though attempts were made to align these QS scheduled aluminium members to the corresponding drawings, they could not be made to not match. As a result it was decided to take the values of Aluminium members as a total of $0.497 \mathrm{~m} 3$. 
TABle 16: The Test Model Aluminium fRAming Schedule EXCerpt

\begin{tabular}{|l|l||l|r|}
\hline Family & Material: Name & Material: Description & $\begin{array}{l}\text { Volume } \\
\left(\mathrm{m}^{3}\right)\end{array}$ \\
\hline Door Material Takeoff & Wooden-AlumFrame_Door_Ext_Int & $850 \times 2032 \mathrm{~mm}$ (Aluminium_Ext) & 0.020 \\
\hline Door Material Takeoff & Aluminium Sliding Door_Ext & $2450 \times 2100 \mathrm{~mm}$ & 0.130 \\
\hline Window Material Takeoff & Window Mullion\&Transom Template & $600 \times 1000(\mathrm{G} 6)$ & 0.042 \\
\hline Window Material Takeoff & Window Mullion\&Transom Template & $1200 \times 1000$ & 0.015 \\
\hline Window Material Takeoff & Window Mullion\&Transom Template & $1490 \times 1200$ & 0.024 \\
\hline Window Material Takeoff & Window Mullion\&Transom Template & $1700 \times 500$ & 0.020 \\
\hline Window Material Takeoff & Window Mullion\&Transom Template & $1700 \times 1100(\mathrm{~J} 16)$ & 0.051 \\
\hline
\end{tabular}

The Test Model permitted the drawings to be followed in more detail, including in modelling the aluminium framing elements. Therefore, the output of these model elements could themselves be specifically identify as Aluminium frame. However, in comparison to the Truth model it falls short by $0.2 \mathrm{~m}^{3}$, suggesting there is an excess amount of unaccounted Aluminium. Although the Test model is based on the information provided by the drawings if the QS assumption is an estimate based on measurement, this would account for the excess of material. In terms of an LCC TPE comparison this has extreme consequences, as aluminium is a potent material in terms of environmental impact. This is clearly shown by the Total Primary Energy Comparison of the two models as it has the largest difference of $629.24 \mathrm{MJ}$ between the two models as well as being the highest TPE in the Truth Model.

Truth Model Volume Total $=0.497$

Test Model Volume Total $=0.302$

Difference of Volume $=\underline{\underline{0.195 m 3}}$
Truth Model TPE $=1513.81$

Test Model TPE $=884.57$

Difference of TPE $=\underline{\underline{629.24}}$

\section{Roof Framing (Materials)}

"Roof Framing (Materials)" is the title given in both models to the upper section between the "Ceiling Framing" and the "Roof Cover Material". In both models this includes the timber framing used in the trusses, the purlins and the soffit and fascia of the surrounding envelope.

\section{Trusses}

The difference between the "Roof Framing (materials)" in the Truth Model and the Test Model is that the Test Model attributes more impact from materials in comparison to that of the Truth Model

Further investigation has found that this is due to differences in the volume of fly rafters. Though the Truth Model volume of rafter elements is taken directly from the QS calculation of the original volume of a rafter member multiplied by quantity of members, the Test Model takes its value from fly rafter truss as a whole volume multiplied by the number of trusses used. This includes any additional timber used in the framing of the truss itself. Although this approach provides a more realistic representation of the account timber materials in the roof framing compared to the Truth Model which accounts for them separately i.e. Fly Rafter, Truss Brace and Nog.

After the completion of the initial analysis, it was found that the truss braces had not been fully included. Table 17 below gives the revised timber volume that matches that calculated by the Revit ${ }^{\mathrm{TM}}$ model. 


\begin{tabular}{|l|l|l|l|l|l|l|}
\hline $\begin{array}{l}\text { Truss Brace } \\
\text { and Nog }\end{array}$ & $108 / 332$ & $\begin{array}{l}90^{*} 45 \text { MSG8 H1.2 KD } \\
\text { GGD }\end{array}$ & 14 & LM & $\begin{array}{l}\text { Timber/treated/kiln/P } \\
\text { G }\end{array}$ & 0.0041 \\
\hline
\end{tabular}

The element "Truss Brace and Nog" in Table 17 was discovered misplaced in the placeholders (Appendix 2) due to a use oversight during the model development period. This detail was extracted and set up for an additional comparison in Table 18.

TABLE 18: THE TRUTH MODEL FRAMING DATA

\begin{tabular}{|l|l|r|}
\hline \multicolumn{1}{|c|}{ Material } & \multicolumn{1}{|c|}{ Details } & Volume $\left(\mathrm{m}^{3}\right)$ \\
\hline Timber, soft wood, sawn kiln-dried sections & Framing Purlins 90*45 MSG8 H1.2 KD GGD & 0.79 \\
\hline Timber, soft wood, sawn kiln-dried sections & Fly Rafters 90*35 MSG8 H1.2 KD GAUGED & 0.48 \\
\hline Timber, soft wood, sawn kiln-dried sections & Soffit Ribbon Plate 70*35 KD MSG8 CF GGD & 0.11 \\
\hline Timber, soft wood, sawn kiln-dried sections & Soffit Framing 70*35 KD MSG8 CF GGD & 0.04 \\
\hline \multicolumn{2}{|l|}{} & $\underline{1.42}$ \\
\hline
\end{tabular}

Table 18 shows that the $1^{\text {st }}$ highest use of timber element of the Truth Model with Framing Purlins which is the total of all the timber purlin element that separate the Roof Cover from the Timber Trusses. Rafters are the second element to follow suit in the $2^{\text {nd }}$ highest account of timber in the Roof. Table 19 lists the soffit members. The displaced data in Table 17 is the leastmost contributing member, as it is included in the support timber members for the Fly Rafters.

TABle 19: The Test Model Framing Data

\begin{tabular}{|l|l|r|}
\hline \multicolumn{1}{|c|}{ Material } & \multicolumn{1}{|c|}{ Details } & Volume $\left(\mathrm{m}^{3}\right)$ \\
\hline Timber, soft wood, sawn kiln-dried sections & $45 \times$ 90mm Purlins & 0.92 \\
\hline Timber, soft wood, sawn kiln-dried sections & $90 \times 35$ Roof Framing Fly Rafters MSG8 H1.2 KD Gauged & 1.32 \\
\hline Timber, soft wood, sawn kiln-dried sections & $70 \times 35$ Soffit Ribbon Plate Roof Framing H1.2 Timber & 0.17 \\
\hline Timber, soft wood, sawn kiln-dried sections & $70 \times 35$ H1.2 Soffit Ribbon Plate & 0.02 \\
\hline Timber, soft wood, sawn kiln-dried sections & $70 \times 35$ H1.2 Soffit Ribbon Plate & 0.02 \\
\hline \multicolumn{2}{|l}{} & $\underline{\underline{2.455}}$ \\
\hline
\end{tabular}

In the Test Model highest material contributor is the Fly Rafters instead of the Purlins. This is due to the total of timber support nogs below the Rafters which are added along with the volume of the Rafters themselves. Since in Revit ${ }^{\mathrm{TM}}$ the Rafters/Trusses were modelled as a group, their material take off is also as a group. Following behind Fly Rafters in the volume contribution is the Purlins with volume just slightly above the Truth Model purlin volume.

\section{Soffit and Fascia Framing}

This is also a difficult aspect of the research as while the QS schedule accounted for soffit ribbon plate and framing, the drawings only show a limited amount as to how many soffit framing members are present. The image below (Figure 26) is the only detail image from the drawings that shows the Soffit Framing Nog. 


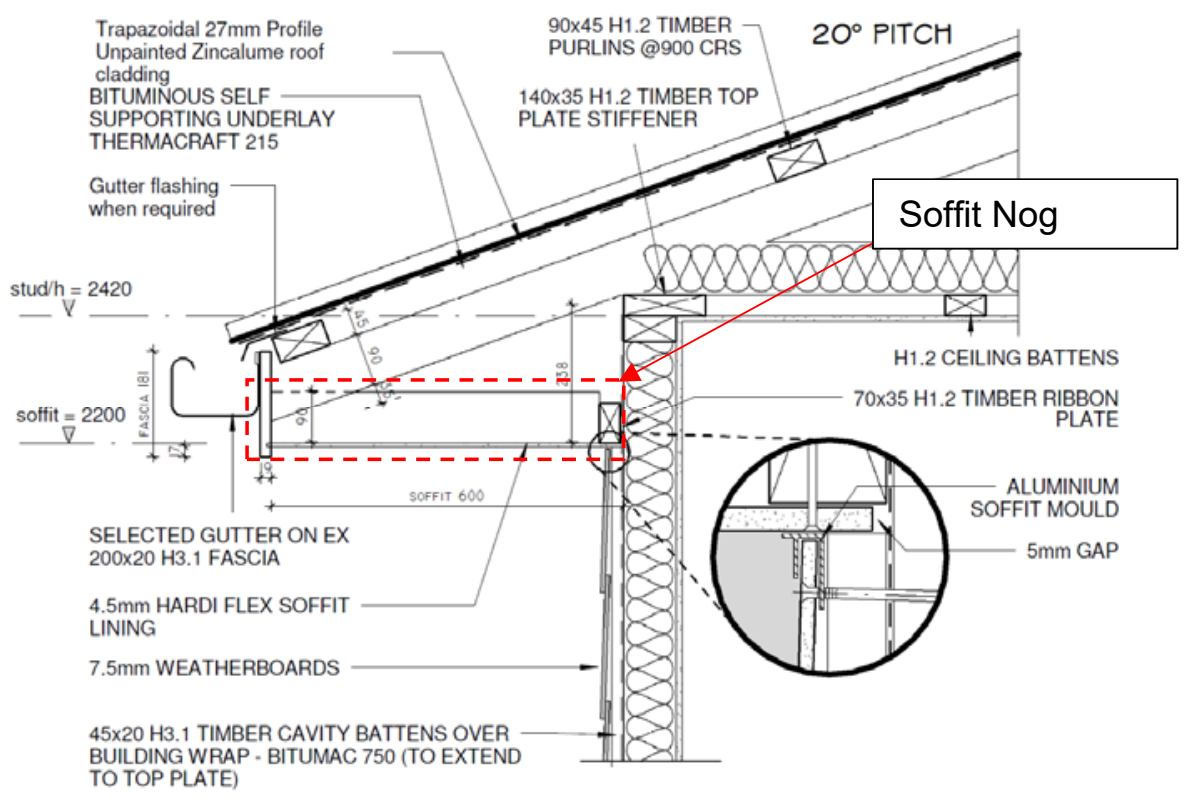

Figure 26: PLAN Extract Showing the Soffit Nog Details

There is insufficient information from elevation views to show the correct number of nogs. Therefore, it was assumed based on construction knowledge, that for a Soffit Board to have sufficient support it would have to account for a Soffit Nog above it that would be nailed to the edge of the fly rafters. From this reasoning there were numerous of Timber Soffit Nogs allocated to each lengthwise of edge of the house that would then offer support for the Soffit Boards.

TABLE 20: TRUth Model ROOF SCHEDULe SOFFIT EXCERPT

\begin{tabular}{|l|l|l|l|}
\hline Family & Material: Name & Material: Description & $\begin{array}{l}\text { Material: } \\
\text { Volume }\end{array}$ \\
\hline $\begin{array}{l}\text { Roof Framing Soffit } \\
\text { Framing }\end{array}$ & $\begin{array}{l}\text { Soffit Framing 70*35 KD } \\
\text { MSG8 CF GGD }\end{array}$ & $\begin{array}{l}\text { Timber, soft wood, sawn kiln-dried } \\
\text { sections }\end{array}$ & 0.04 \\
\hline
\end{tabular}

TABLE 21: TEST MOdEL ROOF SCHEdule SOFFIT EXCERPT

\begin{tabular}{|l|l|l|r|}
\hline Family & Material: Name & Material: Description & Material: Volume \\
\hline Roof Material Take-off & $70 \times 35$ H1.2 Soffit Framing & Timber, soft wood, sawn kiln-dried sections & 0.169 \\
\hline
\end{tabular}

However, the result of this assumption was that there were more volume in the Soffit Nogs in the Test Model (Table 20) than in the Truth Model (Table 21).

\section{Window and Door (Glass Material)}

The Window and Door (Glass Material) Family shows a negative value in the percentage comparison between the models. This is an indication of the Test Model again possessing more impact of materials than that of the Truth Model.

\section{Window and Door (Glass Material): $-10.11 \%$}

The TPE and Volume of Window and Door Glass material has a similar effect as that of the Aluminium Framing. Due to the naming convention of the QS, it was not possible to allocate these members within the drawings (Table 22). The Test Model (Table 23) uses the information provided by the drawings to pinpoint exactly which aluminium-framed window and door uses a 
glass window panel. "LINTEL $190^{*} 45^{\star} 705 \mathrm{H} 1.2$ " is a similar naming style used in the Aluminium framing members. This is just one naming style carried across the board with varying dimensions though when aligning with elements of the drawings that use a glass panel it has proven difficult.

\section{TABLE 22: TRUTH Model WindoW AND DOOR (GLASS MATERIAL) SCHEDULE EXCERPT}

\begin{tabular}{|l|l|l|r|}
\hline \multicolumn{1}{|c|}{ Family } & \multicolumn{1}{|c|}{ Material: Name } & \multicolumn{1}{|c|}{ Material Description } & $\begin{array}{c}\text { Material } \\
\text { Volume }\end{array}$ \\
\hline $\begin{array}{l}\text { Glass for windowsWindow } \\
\text { C6/F6/G6IJ6IL6/M6/R6 }\end{array}$ & $\begin{array}{l}\text { (Glass for Windows) LINTEL } \\
190 * 45 * 705 \text { H1.2 }\end{array}$ & Glass, heat strengthened & 0.01 \\
\hline $\begin{array}{l}\text { (Door) - Glass for windowsWindow } \\
\text { V9/Z9/Z9WZ9-SR9 }\end{array}$ & $\begin{array}{l}\text { (Glass for Windows) LINTEL } \\
190 * 45 * 985 \text { H1.2 }\end{array}$ & Glass, heat strengthened & 0.02 \\
\hline $\begin{array}{l}\text { Glass for windowsWindow C12-2IG12- } \\
\text { 2IJ12-2/M12-2/R12-2 }\end{array}$ & $\begin{array}{l}\text { (Glass for Windows) LINTEL } \\
190 * 45 * 1305 \text { H1.2 }\end{array}$ & Glass, heat strengthened & 0.01 \\
\hline $\begin{array}{l}\text { Glass for windowsWindow } \\
\text { G16/J161T16/X16 }\end{array}$ & (Glass for Windows) LINTEL & Glass, heat strengthened & 0.03 \\
\hline $\begin{array}{l}\text { (Door) - Glass for windowsWindow } \\
\text { C24IG24/L241Y241Y24W/U24IU2 }\end{array}$ & (Glass for Windows) LINTEL & Glass, heat strengthened & 0.04 \\
\hline $\begin{array}{l}\text { (Door) - Glass for windowsWindow } \\
\text { Y281U28 }\end{array}$ & (Glass for Windows) LINTEL & Glass, heat strengthened & 0.10 \\
\hline $\begin{array}{l}\text { Glass for windowsWindow } \\
\text { C6IF6/G6IJ6IL6/M6/R6 }\end{array}$ & $\begin{array}{l}\text { (Glass for Windows) LINTEL } \\
190 * 45 * 705 \text { H1.2 }\end{array}$ & Glass, heat strengthened & 0.00 \\
\hline $\begin{array}{l}\text { Glass for windowsWindow C12-2IG12- } \\
\text { 2/J12-2IM12-21R12-2 }\end{array}$ & (Glass for Windows) LINTEL \\
\hline
\end{tabular}

TABle 23: Test Model Window And Door (Glass Material) Schedule Excerpt

\begin{tabular}{|l|l|l|r|}
\hline Family & Material: Name & Material: Description & Material Volume \\
\hline Wooden-AlumFrame_Door_Ext_Int & $850 \times 2032 \mathrm{~mm}$ (Aluminium_Ext) & Glass, heat strengthened & 0.09 \\
\hline Aluminium Sliding Door_Ext & $2450 \times 2100 \mathrm{~mm}$ & Glass, heat strengthened & 0.25 \\
\hline $\begin{array}{l}\text { Window Mullion\&Transom } \\
\text { Template }\end{array}$ & $600 \times 1000(\mathrm{G} 6)$ & Glass, heat strengthened & 0.01 \\
\hline $\begin{array}{l}\text { Window Mullion\&Transom } \\
\text { Template }\end{array}$ & $1200 \times 1000$ & Glass, heat strengthened & 0.01 \\
\hline $\begin{array}{l}\text { Window Mullion\&Transom } \\
\text { Template }\end{array}$ & $1490 \times 1200$ & Glass, heat strengthened & 0.02 \\
\hline $\begin{array}{l}\text { Window Mullion\&Transom } \\
\text { Template }\end{array}$ & $1700 \times 500$ & Glass, heat strengthened & 0.01 \\
\hline $\begin{array}{l}\text { Window Mullion\&Transom } \\
\text { Template }\end{array}$ & $1700 \times 1100(\mathrm{~J} 16)$ & Glass, heat strengthened & 0.03 \\
\hline
\end{tabular}

For the ease of comparison, the Test Model used the drawings of the house to align the windows and doors. It is from the output were the elements that used glass panels were recorded and the dimensions of the elements were used to try and realign back to the QS data, though that itself was proven difficult. The assumption made at that point was the same assumption made for the Aluminium framing - Take the elements volume as a whole and test to see the outcome. The outcome however states that the Test Model possess more impacts of volume than that of the Truth Model.

\section{Door (Panel)}

There is difference between the Doors of $-61.45 \%$. A closer look at the elements data shows that the Truth Model door volumes (Table 24) are smaller than those in the Test Model (Table 25).

The same trend occurs here as it does with the other Building Family errors, as the Test model aligns its elements with the information provided by the plans. However, the information is different with that of the QS data as the naming convention of elements not only differ but also the element dimensions. 
TABLE 24: TRUTH MODEL DOOR SCHEDULE EXCERPT

\begin{tabular}{|l|l|l|l|l|}
\hline Family: & Type & $\begin{array}{l}\text { Material: } \\
\text { Description }\end{array}$ & $\begin{array}{l}\text { Material: } \\
\text { Volume }\end{array}$ \\
\hline $\begin{array}{l}\text { Interior Doors Singles DOOR FLUSH HG 760*1980 Name } \\
121 \text { LATCH_R }\end{array}$ & 0 & $\begin{array}{l}\text { Timber, soft wood, sawn } \\
\text { kiln-dried sections }\end{array}$ & \\
\hline
\end{tabular}

TABLE 25: TeST MODEL DOORS SCHEDULE EXCERPT

\begin{tabular}{|l|l|l|l|l|}
\hline Family: & Type & $\begin{array}{l}\text { Material: } \\
\text { Description }\end{array}$ & Material: Name & $\begin{array}{l}\text { Material: } \\
\text { Volume }\end{array}$ \\
\hline M_Single-Flush & $\begin{array}{l}760 \mathrm{x} \\
2032 \mathrm{~mm}\end{array}$ & $\begin{array}{l}\text { Timber, soft wood, sawn kiln-dried } \\
\text { Pections }\end{array}$ & \\
\hline
\end{tabular}

The Test Model has $0.59 \mathrm{~m}^{3}$ whereas the Truth Model has $0.46 \mathrm{~m}^{3}$, a $0.13 \mathrm{~m}^{3}$ difference. The only volume alignment that would make sense to compare to would be "Interior Doors Singles 760 * 1980" $\left(0.46 \mathrm{~m}^{3}\right)$ and the "M_Single-Flush $760 \times 2032$ " $\left(0.59 \mathrm{~m}^{3}\right)$. Since "In Cavity Slider Single" is a single sliding door element in the Test Model but the "Interior Doors Single 760*1980" is a generic single panel door - but its volume would suggest it is an accumulation of all single doors used in the house. This is the same for the Test Model where the "M_Single-Flush $760 \mathrm{x}$ 2032" appears to account for all single panel doors. Nevertheless, the Test Model still is well justified based on the drawing information. One possibility is that this is a misinterpretation of the QS data. 


\section{Chapter 6: Results Discussion}

The main point of the research was to design a Test model that would closely match the quantities in the design of a Truth model. The results have shown a greater unexpected outcome than the one that was expected. It has been noted that that though the Test model models most of its elements based on the information provided by the QS data, any missing information has had to be accommodated by using data from the detailed house drawings. The Test model illustrates that a majority of its Revit provided building families have exceeded the quantity and volume density of the Truth model. This would have a larger impact on the result as the later LCAQuick analysis would amplify the results difference margin resulting in a serve consequence of these material differences between the models. Undertaking an origin of error analysis, it was clear that the issue lay in the input of the raw data that could mostly be attributed to human error and the assumptions.

- Is REVIT TM a suitable tool for this work, and what (if any special care needs to be taken?)

The human error and assumptions-made contributed to the lack of understanding the QS data for Revit input stages of modelling. This would be a result of misunderstanding the naming convention that the QS would label a general material family and thus making it difficult for the user to align with the drawings for a detailed modelling process for the Test Model. However, the elements that were close enough in design - the elements with falling within a $10 \%$ margin were able to produce the results that the research was aiming for. Which does provide an indication of how close a BIM model can be modelled to a plan. Table 26 gives the only elements for which a difference of greater than $10 \%$ was found - sub-floor, ceiling framing and exterior wall timber

TABle 26: The "SAFE ThReshold" ElemEnTS

\begin{tabular}{|l|r|r|}
\hline Family & Volume Difference $(\mathrm{m} 3)$ & $\begin{array}{l}\text { Total Primary Energy Difference } \\
(\mathrm{MJ})\end{array}$ \\
\hline Sub Floor & -10.64 & 1.34 \\
\hline Ceiling Framing & 0.15 & 0.06 \\
\hline Exterior Wall Timber & 1.68 & 21.69 \\
\hline
\end{tabular}

- Is LCAQuick a suitable tool for this work, and what (if any) changes are required

Aside from the Test model development, the Truth model has provided its own challenges in the data processing stages. The excess of information and the removed materials (materials that lacked material coefficients e.g. LCAQuick has no material coefficients for ceramic, thus all ceramic-based materials were removed.) showed LCAQuick's inability to reach richer level of detail in information processing. Although this is an issue that is currently being addressed with the development of the tool. However, the research does propose a means/ need for developing a template of information transfer from Quantity of Schedule into LCAQuick format more readily. 
It would be useful to have template that identifies the material LCAQuick can, or cannot, calculate due to the data in its library

\section{The Remaining Elements}

Over the course of the testing stages (Chapter 4) there were elements of both models that could not be compared and were substituted by "placeholders" due to their unnecessary contribution to the requirements of testing. These placeholders are listed in Appendix 2 "Truth Model Placeholders" and the Test model excess materials are given in Appendix 4 "The Unmatched Results of the Test Model". Both highlight a need to understand what is required for modelling. The materials recorded in Appendix 2 are the nails, flashings and glue products. The criteria can be established by what was modelled and tested to define future parameters for modelling of future BIM in LCAQuick.

LCAQuick does not have a simple way to include placeholders, however there is an alternative way to record these elements that is used in the LCAQuick Paint and Washing Schedules. These create a Yes/ No function within Revit ${ }^{\mathrm{TM}}$ where the user can state whether ("Yes") or not ("No") the Elements of the house are washed or painted, and how often. A method of checking also needs to be in place to account for Total amount of House Material Composition versus amount of material being tested. Any materials removed from testing due to a "No" response can be accounted for which will then highlight the amount missing from the tested "Yes" materials e.g. $30 \%$ (Yes) of House materials can be tested as $70 \%$ (No) cannot be found in the LCAQuick library. This is an idea for further discussion with the development team at BRANZ that oversee the LCAQuick tool Development. 


\section{Chapter 7: Conclusion: The Questions that Remain}

In Conclusion, the issue in comparison of material coefficients versus material quantity is that material quantity affects the simulation accuracy due to its variable nature within the LCAQuick formulae. To address the material quantity issue further, the designer of a BPS must design the early sketch with experience or general knowledge. However for a more reliable method a SOQ would enable for a more robust level of detail in design (with the selection of the fundamental model information for predesign stage of course), though a SOQ is only readily available at late design stages. This leaves a large gap in the reliance of the LCAQuick assessment on early sketch design.

In the overall design of the thesis, the Test model was design at a concept level, thus the of difference between the two models was acceptable. The use of $10 \%$ error margin was a goal intended for the ideal precise level of modelling. In both Table 27 and Table 28, the total volume has a difference of just $3.67 \%$. However, at an individual element level, each element varies widely.

At a Total Primary Energy level of analysis the error margin of a total difference amounts to $22.36 \%$, which Chapter 5 results show is due to the of materials potency and quantity in the Truth Model.

TABLE 27: TRUTH MOdEL TOTAL Volume AND TPE

\begin{tabular}{|l|l|r|r|}
\hline \multirow{4}{*}{$\begin{array}{c}\text { Note: The Roof is a Separate element } \\
\text { Calculation done within LCAQuick. }\end{array}$} & With Roof & $\begin{array}{r}\text { Volume Total } \\
(\mathrm{m} 3)\end{array}$ & $\begin{array}{r}\text { Total Primary } \\
\text { Energy Total (MJ) }\end{array}$ \\
\cline { 2 - 4 } & Without Roof & 223.66 & 4386.77 \\
\hline
\end{tabular}

TABLE 28: Test Model TotAl Volume AND TPE

\begin{tabular}{|c|l|r|r|}
\hline \multirow{3}{*}{$\begin{array}{c}\text { Note: The Roof is a Separate element } \\
\text { Calculation done within LCAQuick. }\end{array}$} & & $\begin{array}{r}\text { Volume Total } \\
(\mathrm{m} 3)\end{array}$ & $\begin{array}{r}\text { Total Primary } \\
\text { Energy Total (MJ) }\end{array}$ \\
\cline { 2 - 4 } & With Roof & 47.03 & $3,313.57$ \\
\cline { 2 - 4 } & Without Roof & 43.79 & $3,284.21$ \\
\hline
\end{tabular}

- How accurate is enough to support informed decision-making about building material LCAQuick simulation results?

The analysis results suggest a more refined means of Modelling and Data acquisition needs to be set in place first. The QS data provided for the Truth Model analysis was not only overwhelming in detail but also exceeded the detail, that LCAQuick Residential could accept for analysis. Therefore, a "Template of Criteria" needs to be designed for a LCAQuick analysis to broaden the definition of what general materials it can accept. This template could accept very detailed material listings but summarise them into the level of detail acceptable to LCAQuick. 
- Is the information available in the early phases of the design process for input into LCAQuick, and is it available to the level of detail required to produce accurate results?

Yes, given that the QS data provides sufficient information along with the plan details. These early documents of the construction Life Cycle can support an early LCAQuick analysis. The results themselves from LCAQuick should be able to guide informed decision-making processes of Architectural, Engineering, and Construction (AEC) professionals.

Research Question:

- What level of detail is required of a BIM model to produce consistent results through an LCAQuick calculation?"

The Test Model was designed at a HDM (High Developed Model) level LOD350 (see Table 3 to account for the high amounts of information provided by the Truth Model. However, though the total volume of materials modelled would suggest that a Highly Developed Model would accurately provide results. The outcome of the LCE environmental impact difference shows a wider error margin of inconsistency. To put it directly, a more robust criteria of a material quantity needs to be set between both a Truth model and Test model. This way a reliable trace of material between the two models can set a justifiable comparison to understand the precision of results. Though the level of detail or development may vary, the more detail will always equal more results. 


\section{Chapter 8: Reflection on Research}

The research has established that the three main elements of testing were not well connected enough to establish any useful relationship

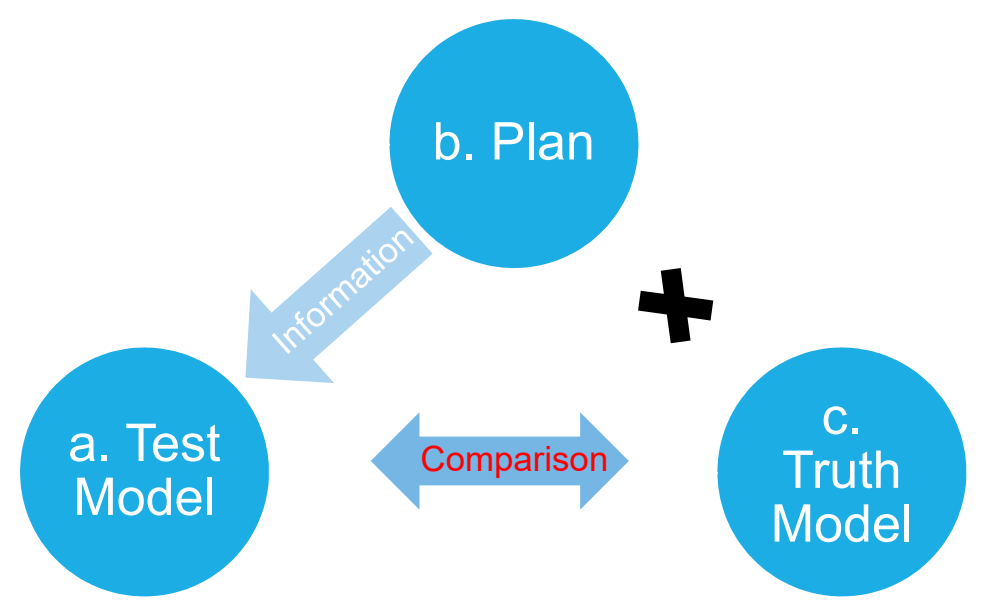

FIGURE 27: A SIMPLIFIED OVERVIEW OF THE MODEL TARGETS BASED ON FIGURE 8 IDENTIFYING THE PATHS OF INFORMATION FLOW NEEDED FOR A SUCCESSFUL COMPARISON TO OCCUR.

\section{a. "Test Model" - "Plan"}

The Test Model was designed based on the details available in the house plans. These details involved geometric information on the housing envelope and the spatial allocation of its elements, with relation to length, width and height. The relationship would allow the justification that the "Test Model" would be the best representation of the existing house design used in the research.

It was considered appropriate to continue to the next stages of the methodology in order to then compare "Test Model" to the "Truth Model".

\section{b. "Plan" - "Truth Model"}

The relationship between the Plan and the Truth Model was not well documented for this research. This was due to the assumption of that if the Truth Model was a Quantity Surveyor's accounting of all materials within the selected home, then a relationship to the Plans would not be needed. As hypothesized by the research, a BIM model (Test Model) was designed accordingly to the Plan can produce a material quantity reliable enough for LCAQuick calculations. To validate the BIM Model, it would be compared to a Quantity Surveyor's schedule of materials (also known in this thesis as the Truth Model).

However, it was not checked that the Truth Model aligned with the Plans. This would allow for a more detailed comparison of the Test Model versus the Truth Model as it can be of Material Volume to Material Volume. 
Material Schedules that could not differentiate between (for example) a door lintel and a window panel (as seen below in Table 29. The Truth Model was also limited in that the QS report used generic names for most elements, but treated each as a separate item. It was then necessary to use volume comparisons based on the QS data to identify which element was which.

\section{Consequence of a lack of Plan to Truth Model relationship.}

In Revit, when modelling Aluminium Doors with Glass panel whether for doors or windows, Revit outputs a schedule with Aluminium Doors and the Glass windows attached to them. This increases the volume of Aluminium used, as shown in Table 29 where the Material Volume is recorded as $0.642 \mathrm{~m}^{3}$

\section{TABLE 29: TEST MODEL ERROR IDENTIFICATION}

\begin{tabular}{|l|r|c|}
\hline \multicolumn{2}{|c|}{ Test Model: Aluminum Framing Materials - Excerpt (First Two Rows Taken Only) } \\
\hline Material: Name & Material: Volume & $\begin{array}{l}\text { Total Primary } \\
\text { Energy }\end{array}$ \\
\hline $\begin{array}{l}\text { Aluminium (powder coated finish, one side } 0.08 \mathrm{~mm} \text { ), extruded } \\
\text { glazing frame, 2.0mm BMT }\end{array}$ & 0.02 & \\
\hline Glass, heat strengthened & 0.09 & \\
\hline & \multicolumn{3}{|c|}{0.642} \\
\hline
\end{tabular}

TABLE 30: TRUTH MOdeL ERROR IDENTIFICATION

\begin{tabular}{|l|r|r|}
\hline \multicolumn{2}{|c|}{ Truth Model: Aluminum Framing Materials - Excerpt (First Two Rows Taken Only) } \\
\hline Material: Name & Material: Volume & $\begin{array}{l}\text { Total Primary } \\
\text { Energy }\end{array}$ \\
\hline $\begin{array}{l}\text { Aluminium (anodised, one side 0.02 mm), profile sheet metal, } \\
\text { generic all profiles, 0.9mm BMT }\end{array}$ & 0.012 & \\
\hline $\begin{array}{l}\text { Aluminium (anodised, one side 0.02 mm), profile sheet metal, } \\
\text { generic all profiles, 0.9mm BMT }\end{array}$ & 0.008 & \\
\hline & 0.49 & 1513.81 \\
\hline
\end{tabular}

The Truth Model (QS Data) does not consolidate Glass windows with the Aluminium Doors. The only information provided was that "Aluminium Lintels" that were recorded in the Aluminium section of materials. Because of this, the Truth Model only consisted of Lintel shaped materials. This is why the volume recorded in Table 30 is lower than that given in Table 29 at $0.497 \mathrm{~m}^{3}$.

So what led to the big difference in Total Primary Energy between Table 29 and Table 30? The Test Model with a higher volume of 0.642 should have a higher TPE than the Truth Model. The error lies in the "Material: Name" column and the issue of not establishing a proper relationship between Truth Model and Plan. The Test Model higher volume uses an "Aluminium (powder coated finish, one side $0.08 \mathrm{~mm}$ ), extruded glazing frame, $2.0 \mathrm{~mm} \mathrm{BMT"} \mathrm{whereas} \mathrm{the} \mathrm{Truth} \mathrm{Model} \mathrm{uses}$ a "Aluminium (anodised, one side $0.02 \mathrm{~mm}$ ), profile sheet metal, generic all profiles, $0.9 \mathrm{~mm}$ BMT". Table 30 has a material that has a higher potential TPE, resulting in a Higher TPE value regardless of volume. 
$63 \mid \mathrm{P}$ a g e 



\section{References}

Alcorn, A. (2010). Global Sustainability and the New Zealand House (PhD Thesis). Wellington: Victoria University of Wellington.

Architecture 2030. (2002). Retrieved 27 Oct 2017, from Architecture 2030: http://architecture2030.org/2030_challenges/2030-challenge/2030-implementationguidelines/

ASHRAE Guideline 2002: Measurement of Energy and Demand Savings. . (2002).

Atieno, O. P. (2009). An Analysis of the Strengths and Limitation of Qualitative and Quantitative Research Paradigms. Kenya: Manside Muliro University of Science and Technology.

Augenbroe, G. (2002). Trends in building simulation. Buildings and Environment.

Baird, G., Donn, M. R., Pool, F., Brander D. S., W., \& Aun, C. S. (1984). Energy Performance of Buildings. Wellington: CRC.

Bastone, S., \& Reeve, D. (2014). Trends in Residential Electricity Consumption. SAPERE, pg 4.

Berg, B. (2014). Using BIM to Calculate Accurate Building Material Quantites for early Design Phase Life Cycle Assessment. Wellington: Victoria University of Wellington.

BIM Acceleration Committee. (Nov 2016). The NZ BIM Handbook. Appendix C: Levels of Development Definitions. Wellington: BIM Acceleration Committee. Retrieved Oct 27, 2017, from https://www.biminnz.co.nz/bim-tools/

Brand, S. (2014). How Buildings Learn: What Happens After They're Built. London: Pheonix Illustrated.

BRANZ. (2014). BRANZ House Insulation Guide 5th edition. Porirua: BRANZ.

Collins, N., Blackmore, A., Drysdale, D., \& Barbara, N. (2010). The environmental impact of the Waitakere NOW Home: A Life Cycle Assessment case study. Beacon.

Davis, J. P., \& Eisenhardt, K. M. (2007). Developing Theory through Simulation Methods.

Donn, M. (1999). Quality Assurance - simulation and the real world. Wellington: Victoria University of Wellington.

Donn, M., Selkowitz, S., \& Bordass, B. (2012). The Building Performance Sketch.

G. , P. K., Scott, P. A., \& Welch, H. E. (1996, June 7). The Shelter Characteristics of TraditionalStyled Inuit Snow Houses.

Gilbert, N., \& Troitzsch, K. (2005). Simulation for the Social Scientist. England: Open University Press.

Inland Revenue Depreciation Guide pg 7. (n.d.). Retrieved from IRD.

Ministry for the Environment. (2009, July). Energy Supply and Demand: Environemental Report Card 2009. Retrieved Oct 27, 2017, from Ministry for the Environment: 
http://www.mfe.govt.nz/sites/default/files/environmental-reporting/energy/energy-supplyand-demand.pdf

NBS - What is Building Information Modelling? (2016, 08 03).

New Zealand BIM Handbook - Appendix C - Level of Development definitions. (2014, 07). Retrieved from MBIE.

NSAI Standards: Irish Standard I.S. EN 15978. (2011).

NZ Construction Industry Council. (2016). Design Guidelines. Retrieved from New Zealand Construction Industry Council: http://nzcic.co.nz/resources/guidelines/

Pidd, M. (2004). Complimentary in systems modelling - Systems modelling. theory and Practice.

Rose, S., Spinks, N., \& Canhoto, A. I. (2015). Management Research: Applying the Principles.

Sidroff, S. (2004). International Energy Agency: Annex 31 Energy-Related Environmental Impact of Buildings: Data Needs and Sources (International Energy Agency Annex 31: EnergyRelated Environmental Impact of Buildings). Canada: Canada Mortagage and Housing Corporation. .

Sims, R., Isaacs, N., Barton, B., Paul, B., Kerr, S., Leaver, J., . . Stephenson, J. (2016).

Transition to a low-carbon economy for New Zealand. the Royal Society of New Zealand - TE APARANGI, (p. pg 15). 
Appendix 1: Truth Model Schedule Sheet

\begin{tabular}{|c|c|c|c|c|c|c|c|c|c|c|c|c|c|}
\hline \multicolumn{14}{|c|}{ TRUTH MODEL } \\
\hline $\begin{array}{l}\text { Categor } \\
y\end{array}$ & Family & Type & $\begin{array}{l}\text { Material: } \\
\text { Description }\end{array}$ & Material: Name & $\begin{array}{l}\text { Mate } \\
\text { rial: } \\
\text { Com } \\
\text { ment } \\
\text { s }\end{array}$ & $\begin{array}{l}\text { CB } \\
\text { l } \\
\text { Co } \\
\text { de }\end{array}$ & $\begin{array}{l}\text { CBI } \\
\text { Descri } \\
\text { ption }\end{array}$ & $\begin{array}{l}\text { BL } \\
\text { AN } \\
K\end{array}$ & $\begin{array}{l}\text { Building } \\
\text { Element } \\
\text { Code }\end{array}$ & \begin{tabular}{|l|} 
Building \\
Element \\
Description
\end{tabular} & \begin{tabular}{|l} 
Mater \\
ial \\
Area
\end{tabular} & $\begin{array}{l}\text { Material: } \\
\text { Volume }\end{array}$ & $\begin{array}{l}\text { Total } \\
\text { Primar } \\
y \\
\text { Energy }\end{array}$ \\
\hline \multirow{10}{*}{$\begin{array}{l}\text { Sub } \\
\text { Floor }\end{array}$} & Sub Floor Timber Timber Piles 1 (Anchor pile) & ANCHOR PILE 1.5M $125 * 125$ SQ H5 & $\begin{array}{l}\text { PR_20_76_8 } \\
8\end{array}$ & Timber, soft wood, sawn kiln-dried sections & 0 & 0 & 0 & 0 & $\begin{array}{l}\text { EE_20_ } \\
20 \_05\end{array}$ & $\begin{array}{l}\text { Lowest Floors } \\
\text { Substructure }\end{array}$ & 0 & 0.2578125 & \\
\hline & $\begin{array}{l}\text { Sub Floor Timber Timber Piles } 2 \text { (Brace pile \& } \\
\text { Standard Pile }\end{array}$ & PILE TAN 125 SQ 1800MM & $\begin{array}{l}\text { PR_20_76_8 } \\
8\end{array}$ & Timber, soft wood, sawn kiln-dried sections & 0 & 0 & 0 & 0 & $\begin{array}{l}\text { EE_20- } \\
20 \_05\end{array}$ & $\begin{array}{l}\text { Lowest Floors } \\
\text { Substructure }\end{array}$ & 0 & 0.06015625 & \\
\hline & Sub Floor Timber Bearers $1 \mathrm{SL}$ & Bearers 1 SL 150*50 H3.2 TW GGD MSG8 & $\begin{array}{l}\text { PR_20_76_8 } \\
8\end{array}$ & Timber, soft wood, sawn kiln-dried sections & 0 & 0 & 0 & 0 & $\begin{array}{l}\text { EE_20_- } \\
20 \_05\end{array}$ & $\begin{array}{l}\text { Lowest Floors } \\
\text { Substructure }\end{array}$ & 0 & 1.84275 & \\
\hline & Sub Floor Timber Floor Joists $3 \mathrm{SL}$ & $\begin{array}{l}\text { Floor Joists } 3 \text { SL 150*50 MSG8 H1.2 F1 G2E } 6.6 \\
\text { JOISTS }\end{array}$ & $\begin{array}{l}\text { PR_20_76_8 } \\
8\end{array}$ & Timber, soft wood, sawn kiln-dried sections & 0 & 0 & 0 & 0 & $\begin{array}{l}\text { EE_20- } \\
20 \_05\end{array}$ & $\begin{array}{l}\text { Lowest Floors } \\
\text { Substructure }\end{array}$ & 0 & 2.3265 & \\
\hline & Sub Floor Timber Boundary Joists (6.6M) & $\begin{array}{l}\text { Boundary Joists (6.6M) } 150 * 50 \mathrm{MSG8} \text { H1.2 F1 G2E } \\
6.6 \text { JOISTS }\end{array}$ & $\begin{array}{l}\text { PR_20_76_8 } \\
8\end{array}$ & Timber, soft wood, sawn kiln-dried sections & 0 & 0 & 0 & 0 & $\begin{array}{l}\text { EE_20- } \\
20 \_05\end{array}$ & $\begin{array}{l}\text { Lowest Floors } \\
\text { Substructure }\end{array}$ & 0 & 0.297 & \\
\hline & $\begin{array}{l}\text { Sub Floor Timber Nogging Under Interior Wall } \\
\text { Framing }\end{array}$ & Nog Under Interior Wall 90*45 MSG8 H1.2 KD GGD & $\begin{array}{l}\text { PR_20_76_8 } \\
8\end{array}$ & Timber, soft wood, sawn kiln-dried sections & 0 & 0 & 0 & 0 & $\begin{array}{l}\text { EE_20- } \\
20 \_05\end{array}$ & $\begin{array}{l}\text { Lowest Floors } \\
\text { Substructure }\end{array}$ & 0 & 0.008262 & \\
\hline & $\begin{array}{l}\text { Sub Floor Timber Solid Mid Row Floor Nogs @ } \\
1800 \text { centre }\end{array}$ & $\begin{array}{l}\text { Solid Mid Row Floor Nogs @ } 1800 \text { centre 150*50 } \\
\text { MSG8 H1.2 F1 G2E 6.6 JOISTS }\end{array}$ & $\begin{array}{l}\text { PR_20_76_8 } \\
8\end{array}$ & Timber, soft wood, sawn kiln-dried sections & 0 & 0 & 0 & 0 & $\begin{array}{l}\text { EE_20- } \\
20 \_05\end{array}$ & $\begin{array}{l}\text { Lowest Floors } \\
\text { Substructure }\end{array}$ & 0 & 0.00255 & \\
\hline & Sub Floor Timber Strong Backs & Strong Backs $100 * 50$ H3.2 TW MSG8 & $\begin{array}{l}\text { PR_20_76_8 } \\
8\end{array}$ & Timber, soft wood, sawn kiln-dried sections & 0 & 0 & 0 & 0 & $\begin{array}{l}\text { EE_20- } \\
20 \_05\end{array}$ & $\begin{array}{l}\text { Lowest Floors } \\
\text { Substructure }\end{array}$ & 0 & 0.092925 & \\
\hline & Sub Floor Timber Flooring & STRANDBOARD $3.60 * 2.40 * 20 \mathrm{~mm}$ UF RESIN & $\begin{array}{l}\text { PR_20_76_8 } \\
8\end{array}$ & Timber, soft wood, sawn kiln-dried sections & 0 & 0 & 0 & 0 & $\begin{array}{l}\text { EE_20- } \\
20 \_05\end{array}$ & $\begin{array}{l}\text { Lowest Floors } \\
\text { Substructure }\end{array}$ & 0 & 2.4192 & \\
\hline & Sub Floor Timber Concrete for piles & $\begin{array}{l}\text { Footing Sizes DN } 400 \mathrm{~mm} \text {, MIN } 17.5 \mathrm{MPa} \text { Concrete } \\
\text { Strength @ } 28 \text { Days }\end{array}$ & $\begin{array}{l}\text { PR_20_31_1 } \\
\text { 6_1_1_1_1 }\end{array}$ & Concrete, $17.5 \mathrm{MPa}$, in-situ, no reinforcement, (OPC) & 0 & 0 & 0 & 0 & $\begin{array}{l}\text { EE_20_- } \\
20 \_05\end{array}$ & $\begin{array}{l}\text { Lowest Floors } \\
\text { Substructure }\end{array}$ & 0 & 1.667875 & \\
\hline
\end{tabular}

\begin{tabular}{|c|c|c|c|c|c|c|c|c|c|c|c|c|}
\hline \multirow{2}{*}{$\begin{array}{c}\text { Isolated } \\
\text { Element } \\
: \\
\text { Battens }\end{array}$} & Wall and Ceiling Framing Ceiling Strapping & BATTEN CEILING KD CF 70*35 NST & $\begin{array}{l}\text { PR_20_76_8 } \\
8\end{array}$ & Timber, soft wood, sawn kiln-dried sections & 0 & 0 & 0 & 0 & $\begin{array}{l}\text { EE_20_ } \\
10 \_10_{-}\end{array}$ & $\begin{array}{l}\text { Roofs } \\
\text { Structure } \\
\end{array}$ & 0 & 0.65337825 \\
\hline & Interior Lining Ceiling Lining 1 & Ceiling Lining $1 \mathrm{GIB} 3600 * 10 \mathrm{MM} \mathrm{TE} / \mathrm{TE}$ & $\begin{array}{l}\text { PR_25_71_5 } \\
\text { 2_37 }\end{array}$ & Gypsum plasterboard & 0 & 0 & 0 & 0 & $\begin{array}{l}\text { EE_25_- } \\
40 \_10\end{array}$ & $\begin{array}{l}\text { Internal Walls } \\
\text { Structure }\end{array}$ & 0 & 1.1232 \\
\hline
\end{tabular}

\begin{tabular}{|c|c|c|c|c|c|c|c|c|c|c|c|c|}
\hline \multirow{4}{*}{$\begin{array}{l}\text { Roof } \\
\text { Framing }\end{array}$} & Roof Framing Purlins & Framing Purlins $90 * 45$ MSG8 H1.2 KD GGD & $\begin{array}{l}\text { PR_20_76_8 } \\
8\end{array}$ & Timber, soft wood, sawn kiln-dried sections & 0 & 0 & 0 & 0 & $\begin{array}{l}\text { EE_20- } \\
10 \_10^{-}\end{array}$ & $\begin{array}{l}\text { Roofs } \\
\text { Structure }\end{array}$ & 0 & 0.7889238 \\
\hline & Roof Framing Fly Rafters & Fly Rafters $90 * 35$ MSG8 H1.2 KD GAUGED & $\begin{array}{l}\text { PR_20_76_8 } \\
8\end{array}$ & Timber, soft wood, sawn kiln-dried sections & 0 & 0 & 0 & 0 & $\begin{array}{l}\text { EE_20 } \\
10 \_10 \\
\end{array}$ & $\begin{array}{l}\text { Roofs } \\
\text { Structure }\end{array}$ & 0 & 0.484785 \\
\hline & Roof Framing Soffit Ribbon Plate & Soffit Ribbon Plate $70^{*} 35 \mathrm{KD}$ MSG8 CF GGD & $\begin{array}{l}\text { PR_20_76_8 } \\
8\end{array}$ & Timber, soft wood, sawn kiln-dried sections & 0 & 0 & 0 & 0 & $\begin{array}{l}E=20 \\
10-10 \\
10\end{array}$ & $\begin{array}{l}\text { Roofs } \\
\text { Structure }\end{array}$ & 0 & 0.1078 \\
\hline & Roof Framing Soffit Framing & Soffit Framing $70 * 35 \mathrm{KD}$ MSG8 CF GGD & $\begin{array}{l}\text { PR_20_76_8 } \\
8\end{array}$ & Timber, soft wood, sawn kiln-dried sections & 0 & 0 & 0 & 0 & $\begin{array}{l}\text { EE_20_ } \\
10 \_10\end{array}$ & $\begin{array}{l}\text { Roofs } \\
\text { Structure }\end{array}$ & 0 & 0.0402143 \\
\hline
\end{tabular}

\begin{tabular}{|c|c|c|c|c|c|c|c|c|c|c|c|c|}
\hline \multirow{4}{*}{$\begin{array}{l}\text { Soffit - } \\
\text { Fascia }\end{array}$} & Soffit-Fascia Fascia Board & FASCIA BOARD H3.1 200*25 5.2M & $\begin{array}{l}\text { PR_20_76_8 } \\
8\end{array}$ & Timber, soft wood, sawn kiln-dried sections & 0 & 0 & 0 & 0 & $\begin{array}{l}\text { EE_20_ } \\
10 \_10\end{array}$ & $\begin{array}{l}\text { Roofs } \\
\text { Structure }\end{array}$ & 0 & 0.208 \\
\hline & Soffit-Fascia Barge Board in Meters & $\begin{array}{l}\text { Barge Board in Meters FASCIA BOARD H3.1 200*25 } \\
5.2 \mathrm{M}\end{array}$ & $\begin{array}{l}\text { PR_20_76_8 } \\
8\end{array}$ & Timber, soft wood, sawn kiln-dried sections & 0 & 0 & 0 & 0 & $\begin{array}{ll}\text { EE_20 } \\
10 \_10_{-}\end{array}$ & $\begin{array}{l}\text { Roofs } \\
\text { Structure }\end{array}$ & 0 & 0.104 \\
\hline & Soffit-Fascia Soffit Lining & SOFFIT $2400 * 600 * 4.5 \mathrm{MM} 401947$ & $\begin{array}{l}\text { PR_25_71_1 } \\
4 \_30\end{array}$ & Fibre cement boards & 0 & 0 & 0 & 0 & $\begin{array}{l}\text { EE_20 } \\
10 \_10\end{array}$ & $\begin{array}{l}\text { Roofs } \\
\text { Structure }\end{array}$ & 0 & 0.10368 \\
\hline & Soffit-Fascia Soffit for Gable Ends & SOFFIT $2400 * 600 * 4.5 \mathrm{MM} 401947$ & PR_25_71_1 & Fibre cement boards & 0 & 0 & 0 & 0 & $\begin{array}{l}\text { EE_20 } \\
10 \_10\end{array}$ & $\begin{array}{l}\text { Roofs } \\
\text { Structure }\end{array}$ & 0 & 0.05184 \\
\hline
\end{tabular}

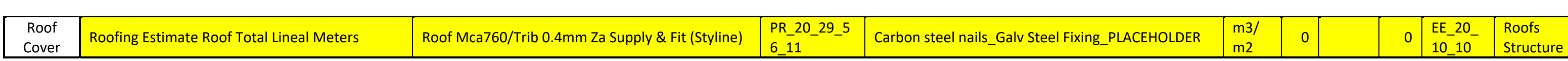

$67 \mid \mathrm{P}$ a g e 


\begin{tabular}{|c|c|c|c|c|c|c|c|c|c|c|c|c|c|}
\hline \multicolumn{14}{|c|}{ TRUTH MODEL } \\
\hline \multirow[t]{2}{*}{$\begin{array}{l}\text { Categor } \\
y\end{array}$} & Family & Type & $\begin{array}{l}\text { Material: } \\
\text { Description }\end{array}$ & Material: Name & $\begin{array}{l}\text { Mate } \\
\text { rial: } \\
\text { Com } \\
\text { ment } \\
\text { s }\end{array}$ & $\begin{array}{l}\text { CB } \\
\text { I } \\
\text { Co } \\
\text { de }\end{array}$ & \begin{tabular}{|l|} 
CBI \\
Descri \\
ption
\end{tabular} & $\begin{array}{l}\text { BL } \\
\text { AN } \\
K\end{array}$ & $\begin{array}{l}\text { Building } \\
\text { Element } \\
\text { Code }\end{array}$ & $\begin{array}{l}\text { Building } \\
\text { Element } \\
\text { Description }\end{array}$ & $\begin{array}{l}\text { Mater } \\
\text { ial } \\
\text { Area }\end{array}$ & $\begin{array}{l}\text { Material: } \\
\text { Volume }\end{array}$ & $\begin{array}{l}\text { Total } \\
\text { Primar } \\
y \\
\text { Energy }\end{array}$ \\
\hline & & & & & & & & & & & & & $\begin{array}{l}4386 . \\
77081 \\
8\end{array}$ \\
\hline \multirow{16}{*}{$\begin{array}{l}\text { Aluminu } \\
\mathrm{m} \text { Total }\end{array}$} & $\begin{array}{l}\text { Aluminium support bar for windowsWindow } \\
\text { C6/F6/G6IJ6IL6/M6/R6 }\end{array}$ & LINTEL $190 * 45 * 705$ H1.2 & $\begin{array}{l}\text { PR_25_71_5 } \\
1 \_ \text {_ } 2 \text { 2 }\end{array}$ & $\begin{array}{l}\text { Aluminium (anodised, one side } 0.02 \mathrm{~mm} \text { ), profile } \\
\text { sheet metal, generic all profiles, } 0.9 \mathrm{~mm} \text { BMT }\end{array}$ & 0 & 0 & 0 & 0 & $\begin{array}{l}\text { EE_25_ } \\
25 \_10\end{array}$ & $\begin{array}{l}\text { External Single } \\
\text { Skin Walls } \\
\text { Structure } \\
\end{array}$ & 0 & 0.0120555 & \\
\hline & $\begin{array}{l}\text { (Door) - Aluminium support bar for } \\
\text { windowsWindow V9/Zg/z9WZ9-SR9 }\end{array}$ & (Door) LINTEL $190 * 45 * 985 \mathrm{H} 1.2$ & $\begin{array}{l}\text { PR_25_71_5 } \\
1 \_ \text {_ } 2 \text { 2 }\end{array}$ & $\begin{array}{l}\text { Aluminium (anodised, one side } 0.02 \mathrm{~mm} \text { ), profile } \\
\text { sheet metal, generic all profiles, } 0.9 \mathrm{~mm} \text { BMT }\end{array}$ & 0 & 0 & 0 & 0 & $\begin{array}{l}\text { EE_25_- } \\
25 \_10\end{array}$ & $\begin{array}{l}\text { External Single } \\
\text { Skin Walls } \\
\text { Structure }\end{array}$ & 0 & 0.00842175 & \\
\hline & $\begin{array}{l}\text { Aluminium support bar for windowsWindow } \\
\text { C12-21G12-2|J12-2/M12-2/R12-2 }\end{array}$ & LINTEL $190 * 45 * 1305 \mathrm{H} 1.2$ & $\begin{array}{l}\text { PR_25_71_5 } \\
\text { 1_3_2 }\end{array}$ & $\begin{array}{l}\text { Aluminium (anodised, one side } 0.02 \mathrm{~mm} \text { ), profile } \\
\text { sheet metal, generic all profiles, } 0.9 \mathrm{~mm} \text { BMT }\end{array}$ & 0 & 0 & 0 & 0 & $\begin{array}{l}\text { EE_25_- } \\
25 \_10\end{array}$ & $\begin{array}{l}\text { External Single } \\
\text { Skin Walls } \\
\text { Structure }\end{array}$ & 0 & 0.001115775 & \\
\hline & $\begin{array}{l}\text { Aluminium support bar for windowsWindow } \\
\text { G16/J161T16/X16 }\end{array}$ & LINTEL $190 * 45 * 1705 \mathrm{H} 1.2$ & $\begin{array}{l}\text { PR_25_71_5 } \\
\text { 1_3_2 }\end{array}$ & $\begin{array}{l}\text { Aluminium (anodised, one side } 0.02 \mathrm{~mm} \text { ), profile } \\
\text { sheet metal, generic all profiles, } 0.9 \mathrm{~mm} \text { BMT }\end{array}$ & 0 & 0 & 0 & 0 & $\begin{array}{l}\text { EE_25 } \\
25 \_10\end{array}$ & $\begin{array}{l}\text { External Single } \\
\text { Skin Walls } \\
\text { Structure }\end{array}$ & 0 & 0.0291555 & \\
\hline & $\begin{array}{l}\text { (Door) - Aluminium support bar for } \\
\text { windowsWindow } \\
\text { C24IG24/L241Y241Y24W/U24IU2 }\end{array}$ & (Door) LINTEL $190 * 45 * 2505 * 2 \mathrm{H} 1.2$ & $\begin{array}{l}\text { PR_25_71_5 } \\
1 \_3 \_2\end{array}$ & $\begin{array}{l}\text { Aluminium (anodised, one side } 0.02 \mathrm{~mm} \text { ), profile } \\
\text { sheet metal, generic all profiles, } 0.9 \mathrm{~mm} \text { BMT }\end{array}$ & 0 & 0 & 0 & 0 & $\begin{array}{l}\text { EE_25_- } \\
25 \_10\end{array}$ & $\begin{array}{l}\text { External Single } \\
\text { Skin Walls } \\
\text { Structure }\end{array}$ & 0 & 0.0428355 & \\
\hline & $\begin{array}{l}\text { (Door) - Aluminium support bar for } \\
\text { windowsWindow Y281U28 }\end{array}$ & (Door) LINTEL $240 * 45 * 2905 * 2 \mathrm{H} 1.2$ & $\begin{array}{l}\text { PR_25_71_5 } \\
1 \_3 \_2\end{array}$ & $\begin{array}{l}\text { Aluminium (anodised, one side } 0.02 \mathrm{~mm} \text { ), profile } \\
\text { sheet metal, generic all profiles, } 0.9 \mathrm{~mm} \text { BMT }\end{array}$ & 0 & 0 & 0 & 0 & $\begin{array}{l}\text { EE_25 } \\
25 \_10\end{array}$ & $\begin{array}{l}\text { External Single } \\
\text { Skin Walls } \\
\text { Structure } \\
\end{array}$ & 0 & 0.125496 & \\
\hline & $\begin{array}{l}\text { Aluminium support bar for windowsWindow } \\
\text { CGIFG/G6IJ6IL6/M6/R6 }\end{array}$ & LINTEL $190 * 45 * 705$ H1.2 & $\begin{array}{l}\text { PR_25_71_5 } \\
1 \_ \text {_ } 2 \text { 2 }\end{array}$ & $\begin{array}{l}\text { Aluminium (anodised, one side } 0.02 \mathrm{~mm} \text { ), profile } \\
\text { sheet metal, generic all profiles, } 0.9 \mathrm{~mm} \text { BMT }\end{array}$ & 0 & 0 & 0 & 0 & $\begin{array}{l}\text { EE_25_ } \\
25 \_10\end{array}$ & $\begin{array}{l}\text { External Single } \\
\text { Skin Walls } \\
\text { Structure } \\
\end{array}$ & 0 & 0.00602775 & \\
\hline & $\begin{array}{l}\text { Aluminium support bar for windowsWindow } \\
\text { C12-2|G12-2/J12-2IM12-21R12-2 }\end{array}$ & LINTEL $190 * 45 * 1305 \mathrm{H} 1.2$ & $\begin{array}{l}\text { PR_25_71_5 } \\
\text { 1_3_2 }\end{array}$ & $\begin{array}{l}\text { Aluminium (anodised, one side } 0.02 \mathrm{~mm} \text { ), profile } \\
\text { sheet metal, generic all profiles, } 0.9 \mathrm{~mm} \text { BMT }\end{array}$ & 0 & 0 & 0 & 0 & $\begin{array}{l}\text { EE_25 } \\
25 \_10\end{array}$ & $\begin{array}{l}\text { External Single } \\
\text { Skin Walls } \\
\text { Structure } \\
\end{array}$ & 0 & 0.01115775 & \\
\hline & $\begin{array}{l}\text { Aluminium support bar for windowsWindow } \\
\text { G16/J161T161X16 }\end{array}$ & LINTEL $190 * 45 * 1705$ H1.2 & $\begin{array}{l}\text { PR_25_71_5 } \\
\text { 1_3_2 }\end{array}$ & $\begin{array}{l}\text { Aluminium (anodised, one side } 0.02 \mathrm{~mm} \text { ), profile } \\
\text { sheet metal, generic all profiles, } 0.9 \mathrm{~mm} \text { BMT }\end{array}$ & 0 & 0 & 0 & 0 & $\begin{array}{l}\text { EE_25- } \\
25 \_10\end{array}$ & $\begin{array}{l}\text { External Single } \\
\text { Skin Walls } \\
\text { Structure } \\
\end{array}$ & 0 & 0.01457775 & \\
\hline & $\begin{array}{l}\text { Aluminium frame for windowsWindow } \\
\mathrm{C} 6 / \mathrm{F} 6 / \mathrm{G} 6 \mathrm{JJ6L} 6 / \mathrm{M} 6 / \mathrm{R} 6\end{array}$ & LINTEL $190 * 45 * 705$ H1.2 & $\begin{array}{l}\text { PR_25_71_5 } \\
1 \_3 \_2\end{array}$ & $\begin{array}{l}\text { Aluminium (anodised, one side } 0.02 \mathrm{~mm} \text { ), profile } \\
\text { sheet metal, generic all profiles, } 0.9 \mathrm{~mm} \text { BMT }\end{array}$ & 0 & 0 & 0 & 0 & $\begin{array}{l}\text { EE_25 } \\
25 \_10\end{array}$ & $\begin{array}{l}\text { External Single } \\
\text { Skin Walls } \\
\text { Structure } \\
\end{array}$ & 0 & 0.0120555 & \\
\hline & $\begin{array}{l}\text { (Door) - Aluminium frame for windowsWindow } \\
\text { v9/Z9/Z9WZ9-SR9 }\end{array}$ & (Door) LINTEL $190 * 45 * 985 \mathrm{H} 1.2$ & $\begin{array}{l}\text { PR_25_71_5 } \\
1 \_3 \_2\end{array}$ & $\begin{array}{l}\text { Aluminium (anodised, one side } 0.02 \mathrm{~mm} \text { ), profile } \\
\text { sheet metal, generic all profiles, } 0.9 \mathrm{~mm} \text { BMT }\end{array}$ & 0 & 0 & 0 & 0 & $\begin{array}{l}\text { EE_25- } \\
25 \_10\end{array}$ & $\begin{array}{l}\text { External Single } \\
\text { Skin Walls } \\
\text { Structure } \\
\end{array}$ & 0 & 0.00842175 & \\
\hline & $\begin{array}{l}\text { Aluminium frame for windowsWindow } \mathrm{C} 12- \\
\text { 2IG12-2IJ12-2/M12-2/R12-2 }\end{array}$ & LINTEL $190 * 45 * 1305 \mathrm{H} 1.2$ & $\begin{array}{l}\text { PR_25_71_5 } \\
1 \_ \text {_ } 2 \text { 2 }\end{array}$ & $\begin{array}{l}\text { Aluminium (anodised, one side } 0.02 \mathrm{~mm} \text { ), profile } \\
\text { sheet metal, generic all profiles, } 0.9 \mathrm{~mm} \text { BMT }\end{array}$ & 0 & 0 & 0 & 0 & $\begin{array}{l}\text { EE_25_ } \\
25 \_10\end{array}$ & $\begin{array}{l}\text { External Single } \\
\text { Skin Walls } \\
\text { Structure } \\
\end{array}$ & 0 & 0.01115775 & \\
\hline & $\begin{array}{l}\text { Aluminium frame for windows Window } \\
\text { G16/1161T16/X16 }\end{array}$ & LINTEL $190 * 45 * 1705$ H1.2 & $\begin{array}{l}\text { PR_25_71_5 } \\
\text { 1_3_2 }\end{array}$ & $\begin{array}{l}\text { Aluminium (anodised, one side } 0.02 \mathrm{~mm} \text { ), profile } \\
\text { sheet metal, generic all profiles, } 0.9 \mathrm{~mm} \text { BMT }\end{array}$ & 0 & 0 & 0 & 0 & $\begin{array}{l}\text { EE_25- } \\
25 \_10\end{array}$ & $\begin{array}{l}\text { External Single } \\
\text { Skin Walls } \\
\text { Structure } \\
\end{array}$ & 0 & 0.0291555 & \\
\hline & $\begin{array}{l}\text { (Door) - Aluminium frame for windowsWindow } \\
\text { C24IG24/L241Y241Y24W/U24IU2 }\end{array}$ & (Door) LINTEL $190 * 45 * 2505 * 2 \mathrm{H} 1.2$ & $\begin{array}{l}\text { PR_25_71_5 } \\
1 \_3 \_2\end{array}$ & $\begin{array}{l}\text { Aluminium (anodised, one side } 0.02 \mathrm{~mm} \text { ), profile } \\
\text { sheet metal, generic all profiles, } 0.9 \mathrm{~mm} \text { BMT }\end{array}$ & 0 & 0 & 0 & 0 & $\begin{array}{l}\text { EE_25_ } \\
25 \_10\end{array}$ & $\begin{array}{l}\text { External Single } \\
\text { Skin Walls } \\
\text { Structure }\end{array}$ & 0 & 0.0428355 & \\
\hline & $\begin{array}{l}\text { (Door) - Aluminium frame for windows Window } \\
\text { Y281U28 }\end{array}$ & (Door) LINTEL $240 * 45 * 2905 * 2 \mathrm{H} 1.2$ & $\begin{array}{l}\text { PR_25_71_5 } \\
1{ }_{1}{ }_{3}{ }_{2} \text { - }\end{array}$ & $\begin{array}{l}\text { Aluminium (anodised, one side } 0.02 \mathrm{~mm} \text { ), profile } \\
\text { sheet metal, generic all profiles, } 0.9 \mathrm{~mm} \text { BMT }\end{array}$ & 0 & 0 & 0 & 0 & $\begin{array}{l}\text { EE_25_ } \\
25 \_10\end{array}$ & $\begin{array}{l}\text { External Single } \\
\text { Skin Walls } \\
\text { Structure }\end{array}$ & 0 & 0.125496 & \\
\hline & $\begin{array}{l}\text { Aluminium frame for windowsWindow } \\
\text { CGIF6/G6IJ6LG/M6/R6 }\end{array}$ & LINTEL $190 * 45 * 705 \mathrm{H} 1.2$ & $\begin{array}{l}\text { PR_25_71_5 } \\
1 \text { 1_3_2 }\end{array}$ & $\begin{array}{l}\text { Aluminium (anodised, one side } 0.02 \mathrm{~mm} \text { ), profile } \\
\text { sheet metal, generic all profiles, } 0.9 \mathrm{~mm} \text { BMT }\end{array}$ & 0 & 0 & 0 & 0 & $\begin{array}{l}\text { EE_25_ } \\
25 \_10\end{array}$ & $\begin{array}{l}\text { External Single } \\
\text { Skin Walls } \\
\text { Structure }\end{array}$ & 0 & 0.00602775 & \\
\hline
\end{tabular}




\begin{tabular}{|c|c|c|c|c|c|c|c|c|c|c|c|c|c|}
\hline \multicolumn{14}{|c|}{ TRUTH MODEL } \\
\hline $\begin{array}{l}\text { Categor } \\
y\end{array}$ & Family & Type & $\begin{array}{l}\text { Material: } \\
\text { Description }\end{array}$ & Material: Name & $\begin{array}{l}\text { Mate } \\
\text { rial: } \\
\text { Com } \\
\text { ment } \\
\mathrm{s}\end{array}$ & $\begin{array}{l}\text { CB } \\
1 \\
\text { Co } \\
\text { de }\end{array}$ & \begin{tabular}{|l} 
CBI \\
Descri \\
ption
\end{tabular} & $\begin{array}{l}\text { BL } \\
\text { AN } \\
K\end{array}$ & $\begin{array}{l}\text { Building } \\
\text { Element } \\
\text { Code }\end{array}$ & $\begin{array}{l}\text { Building } \\
\text { Element } \\
\text { Description }\end{array}$ & $\begin{array}{l}\text { Mater } \\
\text { ial } \\
\text { Area }\end{array}$ & $\begin{array}{l}\text { Material: } \\
\text { Volume }\end{array}$ & $\begin{array}{l}\text { Total } \\
\text { Primar } \\
y \\
\text { Energy }\end{array}$ \\
\hline & $\begin{array}{l}\text { Aluminium frame for windowsWindow } \mathrm{C} 12- \\
2|\mathrm{G} 12-2 / J 12-2| \mathrm{M} 12-21 \mathrm{R} 12-2\end{array}$ & LINTEL $190 * 45 * 1305 \mathrm{H} 1.2$ & $\begin{array}{l}\text { PR_25_71_5 } \\
1 \_3{ }_{-} 2\end{array}$ & $\begin{array}{l}\text { Aluminium (anodised, one side } 0.02 \mathrm{~mm} \text { ), profile } \\
\text { sheet metal, generic all profiles, } 0.9 \mathrm{~mm} \text { BMT }\end{array}$ & 0 & 0 & 0 & 0 & $\begin{array}{l}\text { EE_25_- } \\
25-10\end{array}$ & $\begin{array}{l}\text { External Single } \\
\text { Skin Walls } \\
\text { Structure }\end{array}$ & 0 & 0.01115775 & \\
\hline
\end{tabular}

\begin{tabular}{|c|c|c|c|c|c|c|c|c|c|c|c|c|}
\hline \multirow{8}{*}{ Glass } & $\begin{array}{l}\text { Glass for windowsWindow } \\
\text { C6/F6/G6IJ61L6/M6/R6 }\end{array}$ & (Glass for Windows) LINTEL $190 * 45 * 705$ H1.2 & $\begin{array}{l}\text { PR_25_71_3 } \\
\text { 3_37 }\end{array}$ & Glass, heat strengthened & 0 & 0 & 0 & 0 & $\begin{array}{l}\text { EE_25- } \\
25 \_10\end{array}$ & $\begin{array}{l}\text { External Single } \\
\text { Skin Walls } \\
\text { Structure }\end{array}$ & 0 & 0.009955915 \\
\hline & $\begin{array}{l}\text { (Door) - Glass for windowsWindow } \\
\text { V9/Z9/Z9WZ9-SR9 }\end{array}$ & (Glass for Windows) LINTEL $190 * 45 * 985$ H1.2 & $\begin{array}{l}\text { PR_25_71_3 } \\
\text { 3_37 }\end{array}$ & Glass, heat strengthened & 0 & 0 & 0 & 0 & $\begin{array}{l}\text { EE_25- } \\
25 \_10\end{array}$ & $\begin{array}{l}\text { External Single } \\
\text { Skin Walls } \\
\text { Structure }\end{array}$ & 0 & 0.015488154 \\
\hline & $\begin{array}{l}\text { Glass for windowsWindow C12-21G12-21J12- } \\
\text { 2/M12-2/R12-2 }\end{array}$ & (Glass for Windows) LINTEL $190 * 45 * 1305$ H1.2 & $\begin{array}{l}\text { PR_25_71_3 } \\
3 \_37\end{array}$ & Glass, heat strengthened & 0 & 0 & 0 & 0 & $\begin{array}{l}\text { EE_25- } \\
25 \_10\end{array}$ & $\begin{array}{l}\text { External Single } \\
\text { Skin Walls } \\
\text { Structure }\end{array}$ & 0 & 0.005985382 \\
\hline & Glass for windowsWindow G16/J161T16/X16 & (Glass for Windows) LINTEL $190 * 45 * 1705 \mathrm{H} 1.2$ & $\begin{array}{l}\text { PR_25_71_3 } \\
3 \_37\end{array}$ & Glass, heat strengthened & 0 & 0 & 0 & 0 & $\begin{array}{l}\text { EE_25- } \\
25 \_10\end{array}$ & $\begin{array}{l}\text { External Single } \\
\text { Skin Walls } \\
\text { Structure }\end{array}$ & 0 & 0.031260715 \\
\hline & $\begin{array}{l}\text { (Door) - Glass for windowsWindow } \\
\text { C24IG24/L241Y241Y24W/U24IU2 }\end{array}$ & (Glass for Windows) LINTEL $190 * 45 * 2505 * 2 \mathrm{H} 1.2$ & $\begin{array}{l}\text { PR_25_71_3 } \\
\text { 3_37 }\end{array}$ & Glass, heat strengthened & 0 & 0 & 0 & 0 & $\begin{array}{l}\text { EE_25_ } \\
25 \_10\end{array}$ & $\begin{array}{l}\text { External Single } \\
\text { Skin Walls } \\
\text { Structure }\end{array}$ & 0 & 0.041792058 \\
\hline & (Door) - Glass for windows Window Y281U28 & (Glass for Windows) LINTEL $240 * 45 * 2905 * 2 \mathrm{H} 1.2$ & $\begin{array}{l}\text { PR_25_71_3 } \\
\text { 3_37 }\end{array}$ & Glass, heat strengthened & 0 & 0 & 0 & 0 & $\begin{array}{l}\text { EE_25_ } \\
25 \_10\end{array}$ & $\begin{array}{l}\text { External Single } \\
\text { Skin Walls } \\
\text { Structure } \\
\end{array}$ & 0 & 0.097428276 \\
\hline & $\begin{array}{l}\text { Glass for windowsWindow } \\
\text { C6IF6/G6IJ6/L6/M6/R6 }\end{array}$ & (Glass for Windows) LINTEL $190^{*} 45 * 705$ H1.2 & $\begin{array}{l}\text { PR_25_71_3 } \\
33_{3} 7{ }^{2}\end{array}$ & Glass, heat strengthened & 0 & 0 & 0 & 0 & $\begin{array}{l}\text { EE_25- } \\
25 \_10\end{array}$ & $\begin{array}{l}\text { External Single } \\
\text { Skin Walls } \\
\text { Structure }\end{array}$ & 0 & 0.004977958 \\
\hline & $\begin{array}{l}\text { Glass for windowsWindow C12-21G12-2/J12- } \\
\text { 2IM12-21R12-2 }\end{array}$ & (Glass for Windows) LINTEL $190 * 45 * 1305 \mathrm{H} 1.2$ & $\begin{array}{l}\text { PR_25_71_3 } \\
33_{3} 7 \text { - }\end{array}$ & Glass, heat strengthened & & 0 & 0 & 0 & $\begin{array}{l}\text { EE_25_ } \\
25 \_10\end{array}$ & $\begin{array}{l}\text { External Single } \\
\text { Skin Walls } \\
\text { Structure }\end{array}$ & 0 & 0.005985382 \\
\hline
\end{tabular}

\begin{tabular}{|c|c|c|c|c|c|c|c|c|c|c|c|c|}
\hline \multirow{10}{*}{$\begin{array}{c}\text { Put All } \\
\text { Timber } \\
\text { Material } \\
\text { Here - } \\
\text { Exterior } \\
\text { Wall } \\
\text { Timber } \\
\text { Use } \\
\text { (Total) }\end{array}$} & $\begin{array}{l}\text { Timber reveal/linerWindow } \\
\text { CGIF6/G6IJG6lL6/M6/R6 }\end{array}$ & LINTEL $190 * 45 * 705$ H1.2 & $\begin{array}{l}\text { PR_20_76_8 } \\
8\end{array}$ & Timber, soft wood, sawn kiln-dried sections & 0 & 0 & 0 & 0 & $\begin{array}{ll}\text { EE_25_ } \\
40 \_10\end{array}$ & $\begin{array}{l}\text { Internal Walls } \\
\text { Structure }\end{array}$ & 0 & 0.00707184 \\
\hline & $\begin{array}{l}\text { Timber reveal//inerWindow C12-2|G12-2/J12- } \\
\text { 2IM12-21R12-2 }\end{array}$ & LINTEL $190 * 45 * 1305 \mathrm{H} 1.2$ & $\begin{array}{l}\text { PR_20_76_8 } \\
8\end{array}$ & Timber, soft wood, sawn kiln-dried sections & 0 & 0 & 0 & 0 & $\begin{array}{l}E-25- \\
40-10\end{array}$ & $\begin{array}{l}\text { Internal Walls } \\
\text { Structure }\end{array}$ & 0 & 0.00793584 \\
\hline & Precut Detailed Plates For Ext Frame 1 & $\begin{array}{l}\text { Precut Details for Plates for Ext Frame } 190 * 45 \\
\text { MSG8 H1.2 KD GGD }\end{array}$ & $\begin{array}{l}\text { PR_20_76_8 } \\
8\end{array}$ & Timber, soft wood, sawn kiln-dried sections & 0 & 0 & 0 & 0 & $\begin{array}{l}\text { EE_25_ } \\
25 \_10\end{array}$ & $\begin{array}{l}\text { External Single } \\
\text { Skin Walls } \\
\text { Structure }\end{array}$ & 0 & 0.4455 \\
\hline & Precut Detailed Studs For Ext Frame 1 & Studs For Ext Frame $190 * 45 * 2330$ KD H1.2 MSG8 & $\begin{array}{l}\text { PR_20_76_8 } \\
8\end{array}$ & Timber, soft wood, sawn kiln-dried sections & 0 & 0 & 0 & 0 & $\begin{array}{l}\text { EE_25_ } \\
25-10\end{array}$ & $\begin{array}{l}\text { External Single } \\
\text { Skin Walls } \\
\text { Structure }\end{array}$ & 0 & 1.2361815 \\
\hline & Precut Detailed Plates For Int Frame 1 & Plates For Int Frame $170 * 35 \mathrm{KD}$ MSG8 CF GGD & $\begin{array}{l}\text { PR_20_76_8 } \\
8\end{array}$ & Timber, soft wood, sawn kiln-dried sections & 0 & 0 & 0 & 0 & $\begin{array}{l}E-25- \\
40-10\end{array}$ & $\begin{array}{l}\text { Internal Walls } \\
\text { Structure }\end{array}$ & 0 & 0.19355 \\
\hline & Precut Detailed Studs For Int Frame 1 & Studs For Int Frame $170^{*} 35^{*} 2350 \mathrm{U} / \mathrm{T}$ MSG8 & $\begin{array}{l}\text { PR_20_76_8 } \\
8\end{array}$ & Timber, soft wood, sawn kiln-dried sections & 0 & 0 & 0 & 0 & EE_-25- & $\begin{array}{l}\text { Internal Walls } \\
\text { Structure }\end{array}$ & 0 & 0.6045375 \\
\hline & Precut Detailed Plates For Int Frame 2 & $\begin{array}{l}\text { Precut Detailed Plates for Int Frame } 290^{*} 45 \text { MSG8 } \\
\text { H1.2 KD GGD }\end{array}$ & $\begin{array}{l}\text { PR_20_76_8 } \\
8\end{array}$ & Timber, soft wood, sawn kiln-dried sections & 0 & 0 & 0 & 0 & $\begin{array}{l}\text { EE_25- } \\
40 \_10 \\
\end{array}$ & $\begin{array}{l}\text { Internal Walls } \\
\text { Structure }\end{array}$ & 0 & 0.0243 \\
\hline & Precut Detailed Studs For Int Frame 2 & Studs For Int Frame $290 * 45 * 2330$ KD H1.2 MSG8 & $\begin{array}{l}\text { PR_20_76_8 } \\
8\end{array}$ & Timber, soft wood, sawn kiln-dried sections & 0 & 0 & 0 & 0 & $\begin{array}{ll}\text { EE_25- } \\
40_{-} 10 \\
\end{array}$ & $\begin{array}{l}\text { Internal Walls } \\
\text { Structure }\end{array}$ & 0 & 0.056619 \\
\hline & $\begin{array}{l}\text { Hardie Frontier } 245 \text { I Smooth } 240 \\
\text { Weatherboards 3S_Cavity Battens }\end{array}$ & 3S_Cavity Battens CAVITY BATTEN 50X25 H3.1 & $\begin{array}{l}\text { PR_20_76_8 } \\
8\end{array}$ & Timber, soft wood, sawn kiln-dried sections & 0 & 0 & 0 & 0 & $\begin{array}{l}\text { EE_25_ } \\
25 \_10\end{array}$ & $\begin{array}{l}\text { External Single } \\
\text { Skin Walls } \\
\text { Structure }\end{array}$ & 0 & 0.2975 \\
\hline & $\begin{array}{l}\text { Hardie Frontier 245 I Smooth } 240 \\
\text { Weatherboards 35-Cavity Battens @ Comers }\end{array}$ & $\begin{array}{l}\text { 35-Cavity Battens @ Comers CAVITY BATTEN } \\
100 * 25 \text { H3.1 }\end{array}$ & $\begin{array}{l}\text { PR_20_76_8 } \\
8\end{array}$ & Timber, soft wood, sawn kiln-dried sections & 0 & 0 & 0 & 0 & $\begin{array}{l}\text { EE_25_ } \\
25-10\end{array}$ & $\begin{array}{l}\text { External Single } \\
\text { Skin Walls } \\
\text { Structure }\end{array}$ & 0 & 0.055 \\
\hline
\end{tabular}

69| Page 


\begin{tabular}{|c|c|c|c|c|c|c|c|c|c|c|c|c|c|}
\hline \multicolumn{14}{|c|}{ TRUTH MODEL } \\
\hline $\begin{array}{l}\text { Categor } \\
y\end{array}$ & Family & Type & $\begin{array}{l}\text { Material: } \\
\text { Description }\end{array}$ & Material: Name & $\begin{array}{l}\text { Mate } \\
\text { rial: } \\
\text { Com } \\
\text { ment } \\
\mathrm{s}\end{array}$ & \begin{tabular}{|l} 
CB \\
1 \\
Co \\
de
\end{tabular} & $\begin{array}{l}\text { CBI } \\
\text { Descri } \\
\text { ption }\end{array}$ & \begin{tabular}{|l} 
BL \\
AN \\
K
\end{tabular} & $\begin{array}{l}\text { Building } \\
\text { Element } \\
\text { Code }\end{array}$ & $\begin{array}{l}\text { Building } \\
\text { Element } \\
\text { Description }\end{array}$ & \begin{tabular}{|l} 
Mater \\
ial \\
Area
\end{tabular} & $\begin{array}{l}\text { Material: } \\
\text { Volume }\end{array}$ & \begin{tabular}{|l} 
Total \\
Primar \\
$y$ \\
Energy
\end{tabular} \\
\hline & $\begin{array}{l}\text { Wall and Ceiling Framing Top Plate Packer } \\
\text { Exterior }\end{array}$ & \begin{tabular}{|l}
$\begin{array}{l}\text { Top Plate Packer Exterior 140*35 MSG8 KD H1.2 } \\
\text { (Ext Wall Total) }\end{array}$ \\
\end{tabular} & \begin{tabular}{|l} 
PR_20_76_8 \\
8
\end{tabular} & Timber, soft wood, sawn kiln-dried sections & 0 & 0 & 0 & 0 & $\begin{array}{l}\text { EE_20_ } \\
10_{-} 10_{-} \\
\end{array}$ & \begin{tabular}{|l|l} 
Roofs \\
Structure \\
\end{tabular} & 0 & 0.3626 & \\
\hline & $\begin{array}{l}\text { Framing Hardware Stretcher Stud to Lintel and } \\
\text { Bottom Plate }\end{array}$ & $\begin{array}{l}\text { Stretcher Stud to Lintel and Bottom Plate BRACE } \\
\text { STRAPS 300MM }\end{array}$ & $\begin{array}{l}\text { PR_20_76_8 } \\
8\end{array}$ & Timber, soft wood, sawn kiln-dried sections & 0 & 0 & 0 & 0 & $\begin{array}{l}\text { EEE25- } \\
25 \_10 \\
\end{array}$ & $\begin{array}{l}\text { External Single } \\
\text { Skin Walls } \\
\text { Structure }\end{array}$ & 0 & 0.000539309 & \\
\hline & Lintels \& Beams Window C6/F6/G6IJ6IL6/M6/R6 & LINTEL $190 * 45 * 705$ H1.2 & $\begin{array}{l}\text { PR_20_76_8 } \\
8\end{array}$ & Timber, soft wood, sawn kiln-dried sections & 0 & 0 & 0 & 0 & $\begin{array}{l}\text { EE_25 } \\
25 \_100\end{array}$ & $\begin{array}{l}\text { External Single } \\
\text { Skin Walls } \\
\text { Structure }\end{array}$ & 0 & 0.0120555 & \\
\hline & $\begin{array}{l}\text { (Door) - Lintels \& Beams Window V9/Z9/Z9WZ9- } \\
\text { SR9 }\end{array}$ & (Door) LINTEL $190 * 45 * 985$ H1.2 & $\begin{array}{l}\text { PR_20_76_8 } \\
8\end{array}$ & Timber, soft wood, sawn kiln-dried sections & 0 & 0 & 0 & 0 & $\begin{array}{l}\text { EE_25- } \\
25 \_10\end{array}$ & $\begin{array}{l}\text { External Single } \\
\text { Skin Walls } \\
\text { Structure } \\
\end{array}$ & 0 & 0.00842175 & \\
\hline & $\begin{array}{l}\text { Lintels \& Beams Window C12-2IG12-2IJ12- } \\
\text { 2/M12-2/R12-2 }\end{array}$ & LINTEL $190 * 45 * 1305$ H1.2 & $\begin{array}{l}\text { PR_20_76_8 } \\
8\end{array}$ & Timber, soft wood, sawn kiln-dried sections & 0 & 0 & 0 & 0 & $\begin{array}{l}\text { EE_-25_- } \\
25 \_10\end{array}$ & $\begin{array}{l}\text { External Single } \\
\text { Skin Walls } \\
\text { Structure }\end{array}$ & 0 & 0.01115775 & \\
\hline & Lintels \& Beams Window G16/J161T16/X16 & LINTEL $190 * 45 * 1705 \mathrm{H} 1.2$ & $\begin{array}{l}\text { PR_20_76_8 } \\
8\end{array}$ & Timber, soft wood, sawn kiln-dried sections & 0 & 0 & 0 & 0 & $\begin{array}{l}\text { EE_-25_ } \\
25 \_10\end{array}$ & $\begin{array}{l}\text { External Single } \\
\text { Skin Walls } \\
\text { Structure }\end{array}$ & 0 & 0.0291555 & \\
\hline & $\begin{array}{l}\text { (Door) - Lintels \& Beams Window } \\
\text { C241G24/L241Y241Y24W/U241U2 }\end{array}$ & (Door) LINTEL $190 * 45 * 2505 * 2 \mathrm{H} 1.2$ & $\begin{array}{l}\text { PR_20_76_8 } \\
8\end{array}$ & Timber, soft wood, sawn kiln-dried sections & 0 & 0 & 0 & 0 & $\begin{array}{l}\text { EE_25_ } \\
25 \_10\end{array}$ & $\begin{array}{l}\text { External Single } \\
\text { Skin Walls } \\
\text { Structure }\end{array}$ & 0 & 0.0428355 & \\
\hline & (Door) - Lintels \& Beams Window Y281U28 & (Door) LINTEL $240 * 45 * 2905 * 2 \mathrm{H} 1.2$ & $\begin{array}{l}\text { PR_20_76_8 } \\
8\end{array}$ & Timber, soft wood, sawn kiln-dried sections & 0 & 0 & 0 & 0 & $\begin{array}{l}\text { EE_25_ } \\
25 \_10\end{array}$ & $\begin{array}{l}\text { External Single } \\
\text { Skin Walls } \\
\text { Structure }\end{array}$ & 0 & 0.125496 & \\
\hline & Lintels \& Beams Window C6IF6/G6IJ6IL6/M6/R6 & LINTEL $190 * 45 * 705 \mathrm{H} 1.2$ & $\begin{array}{l}\text { PR_20_76_8 } \\
8\end{array}$ & Timber, soft wood, sawn kiln-dried sections & 0 & 0 & 0 & 0 & $\begin{array}{l}\text { EE_25_ } \\
25 \_10\end{array}$ & $\begin{array}{l}\text { External Single } \\
\text { Skin Walls } \\
\text { Structure }\end{array}$ & 0 & 0.00602775 & \\
\hline & $\begin{array}{l}\text { Lintels \& Beams Window C12-2IG12-2/J12- } \\
\text { 2IM12-21R12-2 }\end{array}$ & LINTEL $190 * 45 * 1305 \mathrm{H} 1.2$ & $\begin{array}{l}\text { PR_20_76_8 } \\
8\end{array}$ & Timber, soft wood, sawn kiln-dried sections & 0 & 0 & 0 & 0 & $\begin{array}{l}\text { EE_25_ } \\
25-10\end{array}$ & $\begin{array}{l}\text { External Single } \\
\text { Skin Walls } \\
\text { Structure }\end{array}$ & 0 & 0.01115775 & \\
\hline & Lintels \& Beams Window G16/J161T161X16 & LINTEL $190 * 45 * 1705$ H1.2 & $\begin{array}{l}\text { PR_20_76_8 } \\
8\end{array}$ & Timber, soft wood, sawn kiln-dried sections & 0 & 0 & 0 & 0 & $\begin{array}{l}\text { EE_-25_ } \\
25 \_10 \\
\end{array}$ & $\begin{array}{l}\text { External Single } \\
\text { Skin Walls } \\
\text { Structure } \\
\end{array}$ & 0 & 0.01457775 & \\
\hline & $\begin{array}{l}\text { Timber reveal/linerWindow } \\
\text { C6/F6/G6IJ6/L6/M6/R6 }\end{array}$ & LINTEL $190 * 45 * 705 \mathrm{H} 1.2$ & $\begin{array}{l}\text { PR_20_76_8 } \\
8\end{array}$ & Timber, soft wood, sawn kiln-dried sections & 0 & 0 & 0 & 0 & $\begin{array}{l}\text { EE_25_ } \\
25 \_10\end{array}$ & $\begin{array}{l}\text { External Single } \\
\text { Skin Walls } \\
\text { Structure } \\
\end{array}$ & 0 & 0.0120555 & \\
\hline & $\begin{array}{l}\text { (Door) - Timber reveal/linerWindow } \\
\text { v9/Zg/ZgWZg-SR9 }\end{array}$ & (Door) LINTEL $190 * 45 * 985$ H1.2 & $\begin{array}{l}\text { PR_20_76_8 } \\
8\end{array}$ & Timber, soft wood, sawn kiln-dried sections & 0 & 0 & 0 & 0 & $\begin{array}{l}\text { EE_25- } \\
40 \_30\end{array}$ & $\begin{array}{l}\text { Internal Walls } \\
\text { Accessible } \\
\text { Openings }\end{array}$ & 0 & 0.00842175 & \\
\hline & $\begin{array}{l}\text { Timber reveal/linerWindow C12-2IG12-2IJ12- } \\
\text { 2/M12-2/R12-2 }\end{array}$ & LINTEL $190 * 45 * 1305 \mathrm{H} 1.2$ & $\begin{array}{l}\text { PR_20_76_8 } \\
8\end{array}$ & Timber, soft wood, sawn kiln-dried sections & 0 & 0 & 0 & 0 & $\begin{array}{l}E-25- \\
40-10\end{array}$ & \begin{tabular}{|l|} 
Internal Walls \\
Structure \\
\end{tabular} & 0 & 0.01115775 & \\
\hline & Timber reveal/linerWindow G16/J161T16/X16 & LINTEL $190 * 45 * 1705$ H1.2 & $\begin{array}{l}\text { PR_20_76_8 } \\
8\end{array}$ & Timber, soft wood, sawn kiln-dried sections & 0 & 0 & 0 & 0 & $\begin{array}{l}\text { EE_25_ } \\
40_{-} 10^{-}\end{array}$ & \begin{tabular}{|l} 
Internal Walls \\
Structure
\end{tabular} & 0 & 0.0291555 & \\
\hline & $\begin{array}{l}\text { (Door) - Timber reveal/linerWindow } \\
\text { C24IG24/L241Y241Y24W/U24IU2 }\end{array}$ & (Door) LINTEL $190 * 45 * 2505 * 2 \mathrm{H} 1.2$ & $\begin{array}{l}\text { PR_20_76_8 } \\
8\end{array}$ & Timber, soft wood, sawn kiln-dried sections & 0 & 0 & 0 & 0 & $\begin{array}{l}\text { EE_25_ } \\
40 \_30\end{array}$ & $\begin{array}{l}\text { Internal Walls } \\
\text { Accessible } \\
\text { Openings }\end{array}$ & 0 & 0.0428355 & \\
\hline & (Door) - Timber reveal/linerWindow Y281U28 & (Door) LINTEL $240 * 45 * 2905 * 2 \mathrm{H} 1.2$ & $\begin{array}{l}\text { PR_20_76_8 } \\
8\end{array}$ & Timber, soft wood, sawn kiln-dried sections & 0 & 0 & 0 & 0 & $\begin{array}{l}\text { EE_25_ } \\
40_{-} 30^{-}\end{array}$ & $\begin{array}{l}\text { Internal Walls } \\
\text { Accessible } \\
\text { Openings }\end{array}$ & 0 & 0.125496 & \\
\hline
\end{tabular}

\begin{tabular}{|c|c|c|c|c|c|c|c|c|c|c|c|c|}
\hline \multirow[t]{2}{*}{$\begin{array}{c}\text { Insulatio } \\
\mathrm{n}\end{array}$} & Insulation Wall Insulation & Wall Insulation R2.2 WALL 13.9M2 & $\begin{array}{l}\text { PR_25_57_6 } \\
\text { _30 }\end{array}$ & Insulation, Glass Wool & 0 & 0 & 0 & 0 & $\begin{array}{l}\text { EE_25_ } \\
25 \_10 \\
\end{array}$ & $\begin{array}{l}\text { External Single } \\
\text { Skin Walls } \\
\text { Structure }\end{array}$ & 0 & 7.4921 \\
\hline & Insulation Ceiling Insulation & Ceiling Insulation R3.2 CEIL 8.4M2/BALE & $\begin{array}{l}\text { PR_25_57_6 } \\
\text { _30 }\end{array}$ & Insulation, Glass Wool & 0 & 0 & 0 & 0 & $\begin{array}{l}\text { EE_20_ } \\
10_{-} 10^{\prime}\end{array}$ & \begin{tabular}{|l|} 
Roofs \\
Structure \\
\end{tabular} & 0 & 11.34 \\
\hline
\end{tabular}




\begin{tabular}{|c|c|c|c|c|c|c|c|c|c|c|c|c|c|}
\hline \multicolumn{14}{|c|}{ TRUTH MODEL } \\
\hline $\begin{array}{l}\text { Categor } \\
y\end{array}$ & Family & Type & $\begin{array}{l}\text { Material: } \\
\text { Description }\end{array}$ & Material: Name & $\begin{array}{l}\text { Mate } \\
\text { rial: } \\
\text { Com } \\
\text { ment } \\
\mathrm{s}\end{array}$ & $\begin{array}{l}\text { CB } \\
\text { I } \\
\text { Co } \\
\text { de }\end{array}$ & $\begin{array}{l}\text { CBI } \\
\text { Descri } \\
\text { ption }\end{array}$ & $\begin{array}{l}\mathrm{BL} \\
\mathrm{AN} \\
\mathrm{K}\end{array}$ & $\begin{array}{l}\text { Building } \\
\text { Element } \\
\text { Code }\end{array}$ & $\begin{array}{l}\text { Building } \\
\text { Element } \\
\text { Description }\end{array}$ & $\begin{array}{l}\text { Mater } \\
\text { ial } \\
\text { Area }\end{array}$ & $\begin{array}{l}\text { Material: } \\
\text { Volume }\end{array}$ & $\begin{array}{l}\text { Total } \\
\text { Primar } \\
\text { y } \\
\text { Energy }\end{array}$ \\
\hline & Insulation Timber Floor Insulation (Koolfoam) & $\begin{array}{l}\text { Timber Floor Insulation (Koolfoam) POLYSTYRENE } \\
\text { U/FLOOR } 1800^{*} 355^{*} 60\end{array}$ & $\begin{array}{l}\text { PR_25_71_1 } \\
\text { 3_2 }\end{array}$ & Insulation, polystyrene expanded (EPS) & 0 & 0 & 0 & 0 & $\begin{array}{l}\text { EE_20_- } \\
20 \_05\end{array}$ & $\begin{array}{l}\text { Lowest Floors } \\
\text { Substructure }\end{array}$ & 0 & 6.55614 & \\
\hline
\end{tabular}

\begin{tabular}{|c|c|c|c|c|c|c|c|c|c|c|}
\hline $\begin{array}{l}\text { Weather } \\
\text { boards }\end{array}$ & $\begin{array}{l}\text { Hardie Frontier } 245 \text { I Smooth } 240 \\
\text { Weatherboards 35_Ext Cladding W/B }\end{array}$ & $\begin{array}{l}\text { 35_Ext Cladding W/B H/PLANK FRONTIER 245MM } \\
400151\end{array}$ & $\begin{array}{l}\text { PR_25_71_1 } \\
4 \text { 4_30 }\end{array}$ & Fibre cement boards & 0 & 0 & 0 & $\begin{array}{l}\text { EE_25 } \\
25 \_10\end{array}$ & $\begin{array}{l}\text { External Single } \\
\text { Skin Walls } \\
\text { Structure }\end{array}$ & 0.9338175 \\
\hline
\end{tabular}

\begin{tabular}{|c|c|c|c|c|c|c|c|c|c|c|c|c|c|}
\hline $\begin{array}{l}\text { Interior } \\
\text { Walls }\end{array}$ & Interior Lining Interior Wall Lining & Interior Wall Lining GIB $3600 * 10 \mathrm{MM} \mathrm{TE} / \mathrm{SQ}$ & $\begin{array}{l}\text { PR_25_71_5 } \\
2 \_37\end{array}$ & Gypsum plasterboard & 0 & 0 & 0 & 0 & $\begin{array}{l}\text { EE_25- } \\
40 \_10\end{array}$ & $\begin{array}{l}\text { Internal Walls } \\
\text { Structure } \\
\end{array}$ & 0 & 2.0304 & \\
\hline & & & & & & & & & & & & 2.0304 & $\begin{array}{r}102.88 \\
89764\end{array}$ \\
\hline \multirow{5}{*}{ Doors } & Interior Doors Interior Doors Singles $760 \times 1980$ & $\begin{array}{l}\text { Interior Doors Singles DOOR FLUSH HG 760*1980 } \\
121 \text { LATCH_L_R }\end{array}$ & $\begin{array}{l}\text { PR_20_76_8 } \\
8\end{array}$ & Timber, soft wood, sawn kiln-dried sections & 0 & 0 & 0 & 0 & $\begin{array}{l}\text { EE_25- } \\
4010\end{array}$ & $\begin{array}{l}\text { Internal Walls } \\
\text { Structure }\end{array}$ & 0 & 0.4604688 & \\
\hline & Interior Doors Linen Cupboard Door & $\begin{array}{l}\text { Linen Cupboard Door DOOR FLUSH HG 510*2270 } \\
121 \text { RIS (R/CATCH INCI) }\end{array}$ & $\begin{array}{l}\text { PR_20_76_8 } \\
8\end{array}$ & Timber, soft wood, sawn kiln-dried sections & 0 & 0 & 0 & 0 & $\begin{array}{ll}\text { EE_25- } \\
40 \_10\end{array}$ & $\begin{array}{l}\text { Internal Walls } \\
\text { Structure }\end{array}$ & 0 & 0.0590427 & \\
\hline & Interior Doors Single Cavity Door & $\begin{array}{l}\text { Single Cavity Door CAV/SI 610-810X1980 HC/MDF } \\
\text { FLUSH PG JAMB INC IOCK CUTOI }\end{array}$ & $\begin{array}{l}\text { PR_20_76_8 } \\
8\end{array}$ & Timber, soft wood, sawn kiln-dried sections & 0 & 0 & 0 & 0 & $\begin{array}{l}\text { EE_25- } \\
40-10\end{array}$ & $\begin{array}{l}\text { Internal Walls } \\
\text { Structure }\end{array}$ & 0 & 0.0280665 & \\
\hline & Interior Doors Wardrobe 1 Doors $2270^{*} 610$ PAIR & $\begin{array}{l}\text { Wardrobe } 1 \text { Doors } 2270 * 610 \text { PAIR DOOR FLUSH } \\
\text { HG } 610^{*} 2270 \text { RfT } 121 \text { PAIR (R/CATCH INCI) }\end{array}$ & $\begin{array}{l}\text { PR_20_76_8 } \\
8\end{array}$ & Timber, soft wood, sawn kiln-dried sections & 0 & 0 & 0 & 0 & $\begin{array}{l}\text { EE_25- } \\
40 \_10\end{array}$ & $\begin{array}{l}\text { Internal Walls } \\
\text { Structure }\end{array}$ & 0 & 0.0280665 & \\
\hline & Interior Doors Wardrobe Door 2270*610 & $\begin{array}{l}\text { Wardrobe Door 2270*610 DOOR FLUSH HG } \\
610^{*} 2270121 \text { RIS (R/CATCH INCI) }\end{array}$ & $\begin{array}{l}\text { PR_20_76_8 } \\
8\end{array}$ & Timber, soft wood, sawn kiln-dried sections & 0 & 0 & 0 & 0 & $\begin{array}{l}\text { EE_25- } \\
40 \_10\end{array}$ & $\begin{array}{l}\text { Internal Walls } \\
\text { Structure }\end{array}$ & 0 & 0.056133 & \\
\hline
\end{tabular}





\section{Appendix 2: The Truth Model Placeholders}

\begin{tabular}{|c|c|c|c|c|c|c|c|c|c|c|c|c|}
\hline \multicolumn{13}{|c|}{ PLACEHOLDERS } \\
\hline Family & Type & $\begin{array}{l}\text { Material: } \\
\text { Description }\end{array}$ & Material: Name & $\begin{array}{l}\text { Material: } \\
\text { Comments }\end{array}$ & $\begin{array}{l}\text { CBI } \\
\text { Cod } \\
\text { e }\end{array}$ & $\begin{array}{l}\text { CBI } \\
\text { Descript } \\
\text { ion }\end{array}$ & BLANK & $\begin{array}{l}\text { Building Element } \\
\text { code }\end{array}$ & $\begin{array}{l}\text { Building } \\
\text { Element } \\
\text { Description }\end{array}$ & $\begin{array}{l}\text { Material } \\
\text { Area }\end{array}$ & Material: Volume & $\begin{array}{l}\text { Total Primary } \\
\text { Energy }\end{array}$ \\
\hline $\begin{array}{l}\text { Sub Floor Timber Standard Pile Connectors (U } \\
\text { Nails stainle }\end{array}$ & $\begin{array}{l}\text { Standard Pile Connectors (U Nails stainle) } \\
\text { U NAIL-S/STEEL }\end{array}$ & $\begin{array}{l}\text { PR_20_29_ } \\
56 \_11\end{array}$ & $\begin{array}{l}\text { Carbon steel nails_Galv } \\
\text { Steel Fixing_PLACEHOLDER }\end{array}$ & 0 & 0 & 0 & $\begin{array}{l}\text { EE_20_- } \\
20 \_05\end{array}$ & $\begin{array}{l}\text { Lowest Floors } \\
\text { Substructure }\end{array}$ & 0 & 0 & 0.000117449 & \\
\hline $\begin{array}{l}\text { Sub Floor Timber Brace Pile Connectors } 2 \\
\text { Flats/s }\end{array}$ & $\begin{array}{l}\text { Brace Pile Connectors } 2 \text { Flats/s } \\
\text { FOUNDATION PACK SIS \#2 FDN2SS }\end{array}$ & $\begin{array}{l}\text { PR_20_29_ } \\
\text { 56_11 }\end{array}$ & $\begin{array}{l}\text { Carbon steel nails_Galv } \\
\text { Steel Fixing_PLACEHOLDER }\end{array}$ & 0 & 0 & 0 & $\begin{array}{l}\text { EE_20_ } \\
20 \_05\end{array}$ & $\begin{array}{l}\text { Lowest Floors } \\
\text { Substructure }\end{array}$ & 0 & 0 & 0.000682703 & \\
\hline $\begin{array}{l}\text { Sub Floor Timber Anchor Pile Connectors } 2 \text { Flat } \\
\text { SIS }\end{array}$ & $\begin{array}{l}\text { Anchor Pile Connectors } 2 \text { Flat SIS } \\
\text { FOUNDATION PACK SIS \#2 FDN2SS }\end{array}$ & $\begin{array}{l}\text { PR_20_29_ } \\
\text { 56_11 }\end{array}$ & $\begin{array}{l}\text { Carbon steel nails_Galv } \\
\text { Steel Fixing_PLACEHOLDER }\end{array}$ & 0 & 0 & 0 & $\begin{array}{l}\text { EE_20- } \\
20 \_05\end{array}$ & $\begin{array}{l}\text { Lowest Floors } \\
\text { Substructure }\end{array}$ & 0 & 0 & 0.000750974 & \\
\hline Sub Floor Timber Bearer End Caps & Bearer End Caps END CAP GALV 150*100 & $\begin{array}{l}\text { PR_20_29_ } \\
\text { 56_11 }\end{array}$ & $\begin{array}{l}\text { Carbon steel nails_Galv } \\
\text { Steel Fixing_PLACEHOLDER }\end{array}$ & 0 & 0 & 0 & $\begin{array}{l}\text { EE_20_ } \\
20 \_05\end{array}$ & $\begin{array}{l}\text { Lowest Floors } \\
\text { Substructure }\end{array}$ & 0 & 0 & 0.000054 & \\
\hline $\begin{array}{l}\text { Sub Floor Timber Brace Pile Connectors } 1 \\
\text { Twisties SIS }\end{array}$ & $\begin{array}{l}\text { Brace Pile Connectors } 1 \text { Twisties SIS } \\
\text { FOUNDATION PACK SIS \#1 FDN1SS }\end{array}$ & $\begin{array}{l}\text { PR_20_29_ } \\
\text { 56_11 }\end{array}$ & $\begin{array}{l}\text { Carbon steel nails_Galv } \\
\text { Steel Fixing_PLACEHOLDER }\end{array}$ & 0 & 0 & 0 & $\begin{array}{l}\text { EE_20- } \\
20 \_05\end{array}$ & $\begin{array}{l}\text { Lowest Floors } \\
\text { Substructure }\end{array}$ & 0 & 0 & 0.000918284 & \\
\hline $\begin{array}{l}\text { Sub Floor Timber Anchor Pile Connectors } 1 \\
\text { Twisties SIS }\end{array}$ & $\begin{array}{l}\text { Anchor Pile Connectors } 1 \text { Twisties SIS } \\
\text { FOUNDATION PACK SIS \#1 FDN1SS }\end{array}$ & $\begin{array}{ll}\text { PR_20_29_ } \\
\text { 56_11 }\end{array}$ & $\begin{array}{l}\text { Carbon steel nails_Galv } \\
\text { Steel Fixing_PLACEHOLDER }\end{array}$ & 0 & 0 & 0 & EE_20- & $\begin{array}{l}\text { Lowest Floors } \\
\text { Substructure }\end{array}$ & 0 & 0 & 0.001010113 & \\
\hline Sub Floor Timber Z Nails RH & Z NAILS L/HAND S/STEEL & $\begin{array}{ll}\text { PR_20_29_ } \\
\text { 56_11 }\end{array}$ & $\begin{array}{l}\text { Carbon steel nails_Galv } \\
\text { Steel Fixing_PLACEHOLDER }\end{array}$ & 0 & 0 & 0 & 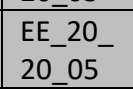 & $\begin{array}{l}\text { Lowest Floors } \\
\text { Substructure }\end{array}$ & 0 & 0 & 0.000133464 & \\
\hline $\begin{array}{l}\text { Sub Floor Timber Bolts } 12 \mathrm{~mm} \mathrm{C/W} \text { Washers and } \\
\text { nuts }\end{array}$ & BOLT S/S316 M12*180 + NUT & $\begin{array}{ll}\text { PR_20_29_ } \\
\text { 56_11 }\end{array}$ & $\begin{array}{l}\text { Carbon steel nails_Galv } \\
\text { Steel Fixing_PLACEHOLDER }\end{array}$ & 0 & 0 & 0 & $\begin{array}{l}=20-2 \\
\text { EE_20 } \\
20-05\end{array}$ & $\begin{array}{l}\text { Lowest Floors } \\
\text { Substructure }\end{array}$ & 0 & 0 & 0.000100991 & \\
\hline $\begin{array}{l}\text { Sub Floor Timber Bolts } 12 \mathrm{~mm} \mathrm{C/W} \text { Washers and } \\
\text { nuts }\end{array}$ & BOLT S/S316 M12*220 + NUT & $\begin{array}{l}\text { PR_20_29_ } \\
\text { 56_11 }\end{array}$ & $\begin{array}{l}\text { Carbon steel nails_Galv } \\
\text { Steel Fixing_PLACEHOLDER }\end{array}$ & 0 & 0 & 0 & $\begin{array}{l}\text { EE_20_- } \\
20-05\end{array}$ & $\begin{array}{l}\text { Lowest Floors } \\
\text { Substructure }\end{array}$ & 0 & 0 & $8.42256 \mathrm{E}-05$ & \\
\hline $\begin{array}{l}\text { Sub Floor Timber Bolts } 12 \mathrm{~mm} \mathrm{C} / \mathrm{W} \text { Washers and } \\
\text { nuts }\end{array}$ & BOLT S/S316 M12*240+NUT & $\begin{array}{l}\text { PR_20_29_ } \\
\text { 56_11 }\end{array}$ & $\begin{array}{l}\text { Carbon steel nails_Galv } \\
\text { Steel Fixing_PLACEHOLDER }\end{array}$ & 0 & 0 & 0 & $\begin{array}{l}E E_{2} 20- \\
20 \_05\end{array}$ & \begin{tabular}{|l|} 
Lowest Floors \\
Substructure \\
\end{tabular} & 0 & 0 & 0.00021236 & \\
\hline Framing Hardware Bracing Element Fixings & $\begin{array}{l}\text { Bracing Element Fixings BRACE STRAP } \\
\text { 400MM }\end{array}$ & $\begin{array}{l}\text { PR_20_29_ } \\
\text { 56_11 }\end{array}$ & $\begin{array}{l}\text { Carbon steel nails_Galv } \\
\text { Steel Fixing_PLACEHOLDER }\end{array}$ & 0 & 0 & 0 & 25_25- & $\begin{array}{l}\text { External Single Skin } \\
\text { Walls Structure } \\
\end{array}$ & 0 & 0 & 0.0000192 & \\
\hline Framing Hardware Top plate connectors & Top plate connectors NAIL PLATE $80 \times 34$ & $\begin{array}{l}\text { PR_20_29_ } \\
\text { 56_11 }\end{array}$ & $\begin{array}{l}\text { Carbon steel nails_Galv } \\
\text { Steel Fixing_PLACEHOLDER }\end{array}$ & 0 & 0 & 0 & $\begin{array}{l}\text { EE_25_ } \\
25 \_10\end{array}$ & $\begin{array}{l}\text { External Single Skin } \\
\text { Walls Structure }\end{array}$ & 0 & 0 & $8.91072 \mathrm{E}-05$ & \\
\hline $\begin{array}{l}\text { Framing Hardware Studs to Top Plate Nail Plates } \\
\text { for Lite }\end{array}$ & $\begin{array}{l}\text { Studs to Top Plate Nail Plates for Lite } \\
\text { BRACE STRAP 400MM }\end{array}$ & $\begin{array}{l}\text { PR_20_29_ } \\
\text { 56_11 }\end{array}$ & $\begin{array}{l}\text { Carbon steel nails_Galv } \\
\text { Steel Fixing_PLACEHOLDER }\end{array}$ & 0 & 0 & 0 & $\begin{array}{l}2525- \\
25 \_10\end{array}$ & $\begin{array}{l}\text { External Single Skin } \\
\text { Walls Structure } \\
\end{array}$ & 0 & 0 & 0.000285732 & \\
\hline $\begin{array}{l}\text { Framing Hardware Stud to Top Plate (Gang Nail } \\
\text { T Stud Strap) }\end{array}$ & $\begin{array}{l}\text { Stud to Top Plate (Gang Nail T Stud Strap) } \\
\text { STUD STRAP }\end{array}$ & $\begin{array}{l}\text { PR_20_29_ } \\
\text { 56_11 }\end{array}$ & $\begin{array}{l}\text { Carbon steel nails_Galv } \\
\text { Steel Fixing_PLACEHOLDER }\end{array}$ & 0 & 0 & 0 & $\begin{array}{l}\text { EE_25- } \\
25 \_10\end{array}$ & $\begin{array}{l}\text { External Single Skin } \\
\text { Walls Structure }\end{array}$ & 0 & 0 & 0.000206388 & \\
\hline $\begin{array}{l}\text { Framing Hardware Sill_Jamb Packer PEF Rod } \\
\text { 10MM }\end{array}$ & $\begin{array}{l}\text { Sill_Jamb Packer PEF Rod 10MM PEF ROD } \\
\text { 50M ROLL }\end{array}$ & $\begin{array}{ll}\text { PR_20_29_ } \\
\text { 56_11 }\end{array}$ & $\begin{array}{l}\text { Carbon steel nails_Galv } \\
\text { Steel Fixing_PLACEHOLDER }\end{array}$ & 0 & 0 & 0 & EE_25- & $\begin{array}{l}\text { External Single Skin } \\
\text { Walls Structure }\end{array}$ & 0 & 0 & 0.003926991 & \\
\hline Framing Hardware Head Flashing Seal & MASKING TAPE VINYL WHITE & $\begin{array}{l}\text { PR_20_29_ } \\
\text { 56_11 }\end{array}$ & $\begin{array}{l}\text { Carbon steel nails_Galv } \\
\text { Steel Fixing_PLACEHOLDER }\end{array}$ & 0 & 0 & 0 & $\begin{array}{l}E-25- \\
25 \_10\end{array}$ & $\begin{array}{l}\text { External Single Skin } \\
\text { Walls Structure }\end{array}$ & 0 & 0 & 0.00018 & \\
\hline Framing Hardware Coach Screws 1 & COACH SCREW M12*150 GALVANISED & $\begin{array}{l}\text { PR_20_29_ } \\
\text { 56_11 }\end{array}$ & $\begin{array}{l}\text { Carbon steel nails_Galv } \\
\text { Steel Fixing_PLACEHOLDER }\end{array}$ & 0 & 0 & 0 & $\begin{array}{l}\text { EE_25_ } \\
25-10\end{array}$ & $\begin{array}{l}\text { External Single Skin } \\
\text { Walls Structure }\end{array}$ & 0 & 0 & $6.78584 \mathrm{E}-05$ & \\
\hline Framing Hardware Galv Square Washers & WASHER SQR GALV M12*50*50*3 & $\begin{array}{l}\text { PR_20_29_ } \\
\text { 56_11 }\end{array}$ & $\begin{array}{l}\text { Carbon steel nails_Galv } \\
\text { Steel Fixing_PLACEHOLDER }\end{array}$ & 0 & 0 & 0 & $\begin{array}{ll}\text { EE_25- } \\
25 \_10\end{array}$ & $\begin{array}{l}\text { External Single Skin } \\
\text { Walls Structure }\end{array}$ & 0 & 0 & $2.84072 \mathrm{E}-05$ & \\
\hline Roof Framing Purlin Fixings & $\begin{array}{l}\text { Purlin Fixings NAILS SPIRAL ROLLED GALV } \\
90 * 3.55\end{array}$ & $\begin{array}{ll}\text { PR_20_29_ } \\
\text { 56_11 }\end{array}$ & $\begin{array}{l}\text { Carbon steel nails_Galv } \\
\text { Steel Fixing_PLACEHOLDER }\end{array}$ & 0 & 0 & 0 & $\begin{array}{ll}\text { EE_20- } \\
10 \_10\end{array}$ & Roofs Structure & 0 & 0 & $5.34491 \mathrm{E}-06$ & \\
\hline Roof Framing Roof Plane Brace 1 & $\begin{array}{l}\text { Roof Plane Brace } 190 * 35 \text { MSG8 H1.2 KD } \\
\text { GAUGED }\end{array}$ & $\begin{array}{l}\text { PR_20_29_ } \\
\text { 56_11 }\end{array}$ & $\begin{array}{l}\text { Carbon steel nails_Galv } \\
\text { Steel Fixing_PLACEHOLDER }\end{array}$ & 0 & 0 & 0 & $\begin{array}{l}\text { EE_20_- } \\
10 \_10\end{array}$ & Roofs Structure & 0 & 0 & 0.07875 & \\
\hline Roofing Estimate Fixings & $\begin{array}{l}\text { Fixings Screws (T-Rib Mc760 Mc700) Za } \\
\text { Supply \& Fit }\end{array}$ & $\begin{array}{l}\text { PR_20_29_ } \\
\text { 56_11 }\end{array}$ & $\begin{array}{l}\text { Carbon steel nails_Galv } \\
\text { Steel Fixing_PLACEHOLDER }\end{array}$ & 0 & 0 & 0 & $\begin{array}{l}\text { EE_20- } \\
10 \_10\end{array}$ & Roofs Structure & 0 & 0 & 0.002020285 & \\
\hline Roofing Estimate Rivets_ZA SUPPLY \& FIT & Rivets_Za Supply \& Fit & $\begin{array}{l}\text { PR_20_29_ } \\
\text { 56_11 }\end{array}$ & $\begin{array}{l}\text { Carbon steel nails_Galv } \\
\text { Steel Fixing_PLACEHOLDER }\end{array}$ & 0 & 0 & 0 & $\begin{array}{l}\text { EE_20- } \\
10 \_10_{-}\end{array}$ & Roofs Structure & 0 & 0 & 0.0105 & \\
\hline Roofing Estimate Gable/Barge Flashing & $\begin{array}{l}\text { Gable/Barge Flashing E2 Barge_Za Supply } \\
\text { \& Fit }\end{array}$ & $\begin{array}{l}\text { PR_20_29_ } \\
\text { 56_11 }\end{array}$ & $\begin{array}{l}\text { Carbon steel nails_Galv } \\
\text { Steel Fixing_PLACEHOLDER }\end{array}$ & 0 & 0 & 0 & $\begin{array}{l}\text { EE_20- } \\
10 \_10_{-} \\
\end{array}$ & Roofs Structure & 0 & 0 & 0.0015675 & \\
\hline $\begin{array}{l}\text { Hardie Frontier 245 I Smooth } 240 \\
\text { Weatherboards 35_Meter Box Flashing (single } \\
\text { Phase) }\end{array}$ & $\begin{array}{l}\text { 3S_Meter Box Flashing (single Phase) } \\
\text { METER BOX FLASHING }\end{array}$ & $\begin{array}{l}\text { PR_20_29_ } \\
\text { 56_11 }\end{array}$ & $\begin{array}{l}\text { Carbon steel nails_Galv } \\
\text { Steel Fixing_PLACEHOLDER }\end{array}$ & 0 & 0 & 0 & $\begin{array}{l}\text { EE_25- } \\
25 \_10\end{array}$ & $\begin{array}{l}\text { External Single Skin } \\
\text { Walls Structure }\end{array}$ & 0 & 0 & 0.000024 & \\
\hline Interior Lining Fixings for Walls & $\begin{array}{l}\text { Fixings for Walls GIB SCREWS } 6 * 25 \mathrm{MM} \\
\text { COLL'D } 1000 \mathrm{BX}\end{array}$ & $\begin{array}{l}\text { PR_20_29_ } \\
\text { 56_11 }\end{array}$ & $\begin{array}{l}\text { Carbon steel nails_Galv } \\
\text { Steel Fixing_PLACEHOLDER }\end{array}$ & 0 & 0 & 0 & $\begin{array}{l}\text { EE_25_- } \\
40 \_10\end{array}$ & $\begin{array}{l}\text { Internal Walls } \\
\text { Structure }\end{array}$ & 0 & 0 & 0.0021195 & \\
\hline
\end{tabular}




\begin{tabular}{|c|c|c|c|c|c|c|c|c|c|c|c|c|}
\hline \multicolumn{13}{|c|}{ PLACEHOLDERS } \\
\hline Family & Type & $\begin{array}{l}\text { Material: } \\
\text { Description }\end{array}$ & Material: Name & $\begin{array}{l}\text { Material: } \\
\text { Comments }\end{array}$ & $\begin{array}{l}\text { CBI } \\
\text { Cod } \\
\text { e } \\
\end{array}$ & \begin{tabular}{|l|} 
CBI \\
Descript \\
ion \\
\end{tabular} & BLANK & $\begin{array}{l}\text { Building Element } \\
\text { code }\end{array}$ & $\begin{array}{l}\text { Building } \\
\text { Element } \\
\text { Description } \\
\end{array}$ & $\begin{array}{l}\text { Material } \\
\text { Area }\end{array}$ & Material: Volume & $\begin{array}{l}\text { Total Primary } \\
\text { Energy }\end{array}$ \\
\hline Interior Lining Gib All Bond & Gib All Bond GIB FIX ONE 4LT & $\begin{array}{l}\text { PR_20_29_ } \\
56 \_11\end{array}$ & $\begin{array}{l}\text { Carbon steel nails_Galv } \\
\text { Steel Fixing_PLACEHOLDER }\end{array}$ & 0 & 0 & 0 & $\begin{array}{l}\text { EE_25_- } \\
40 \_10\end{array}$ & $\begin{array}{l}\text { Internal Walls } \\
\text { Structure }\end{array}$ & 0 & 0 & 0.008 & \\
\hline Interior Lining Fixings for Walls -GS1(10) & $\begin{array}{l}\text { Fixings for Walls -GS1(10) GIB SCREWS } \\
6 * 30 \mathrm{MM} \text { COLL'D 1000BX }\end{array}$ & $\begin{array}{l}\text { PR_20_29_ } \\
\text { 56_-11 }\end{array}$ & $\begin{array}{l}\text { Carbon steel nails_Galv } \\
\text { Steel Fixing_PLACEHOLDER }\end{array}$ & 0 & 0 & 0 & $\begin{array}{l}E-25- \\
40-10 \\
\end{array}$ & $\begin{array}{l}\text { Internal Walls } \\
\text { Structure }\end{array}$ & 0 & 0 & 0.0008478 & \\
\hline Interior Lining Maxibond & Maxibond ADHESIVE MAXI BOND 375ML & $\begin{array}{l}\text { PR_20_29_ } \\
\text { 56_11 }\end{array}$ & $\begin{array}{l}\text { Carbon steel nails_Galv } \\
\text { Steel Fixing_PLACEHOLDER }\end{array}$ & 0 & 0 & 0 & $\begin{array}{ll}E E & 25- \\
40 \_10 \\
\end{array}$ & $\begin{array}{l}\text { Internal Walls } \\
\text { Structure }\end{array}$ & 0 & 0 & 0.00075 & \\
\hline Interior Lining Bath Lining & $\begin{array}{l}\text { Bath Lining H/GLAZE } 2400 * 900 * 4.5 \mathrm{MM} \\
\text { WHITE } 400225\end{array}$ & $\begin{array}{l}\text { PR_20_29- } \\
\text { PR_11 }\end{array}$ & $\begin{array}{l}\text { Carbon steel nails_Galv } \\
\text { Steel Fixing_PLACEHOLDER }\end{array}$ & 0 & 0 & 0 & $\begin{array}{l}\text { EE_25- } \\
40 \_10\end{array}$ & $\begin{array}{l}\text { Internal Walls } \\
\text { Structure }\end{array}$ & 0 & 0 & 0.00972 & \\
\hline Interior Lining Internal Corner & $\begin{array}{l}\text { Internal Corner INT CNR 4.5MM*2400 W } \\
\text { H/GLAZE } 300686\end{array}$ & $\begin{array}{l}\text { PR_20_29_ } \\
\text { 56_-11 }\end{array}$ & $\begin{array}{l}\text { Carbon steel nails_Galv } \\
\text { Steel Fixing_PLACEHOLDER }\end{array}$ & 0 & 0 & 0 & $\begin{array}{l}\text { EE_25- } \\
40 \_10\end{array}$ & $\begin{array}{l}\text { Internal Walls } \\
\text { Structure }\end{array}$ & 0 & 0 & 0.000144 & \\
\hline Interior Lining External Corner & $\begin{array}{l}\text { External Corner EXT CNR 4.5MM*2400 W } \\
\text { H/GLAZE } 300682\end{array}$ & $\begin{array}{l}\text { PR_20_29_ } \\
\text { 56_-11 }\end{array}$ & $\begin{array}{l}\text { Carbon steel nails_Galv } \\
\text { Steel Fixing_PLACEHOLDER }\end{array}$ & 0 & 0 & 0 & $\begin{array}{l}E-25- \\
40-10 \\
\end{array}$ & $\begin{array}{l}\text { Internal Walls } \\
\text { Structure }\end{array}$ & 0 & 0 & 0.0001728 & \\
\hline Interior Lining Cap Mould & $\begin{array}{l}\text { Cap Mould CAPPING 4.5MM*2400 W } \\
\text { H/GLAZE } 300678\end{array}$ & $\begin{array}{l}\text { PR_20_29_ } \\
\text { 56_11 }\end{array}$ & $\begin{array}{l}\text { Carbon steel nails_Galv } \\
\text { Steel Fixing_PLACEHOLDER }\end{array}$ & 0 & 0 & 0 & $\begin{array}{l}\text { EE_25- } \\
40_{-} 10 \\
\end{array}$ & $\begin{array}{l}\text { Internal Walls } \\
\text { Structure }\end{array}$ & 0 & 0 & 0.0003024 & \\
\hline Interior Lining Ceiling Lining 1 & Ceiling Lining 1 GIB 3600*10MM TE/TE & $\begin{array}{l}\text { PR_20_29_ } \\
\text { 56_11 }\end{array}$ & $\begin{array}{l}\text { Carbon steel nails_Galv } \\
\text { Steel Fixing_PLACEHOLDER }\end{array}$ & 0 & 0 & 0 & $\begin{array}{ll}\text { EE_25- } \\
40 \_10 \\
\end{array}$ & $\begin{array}{l}\text { Internal Walls } \\
\text { Structure }\end{array}$ & 0 & 0 & 1.1232 & \\
\hline Interior Lining Fixings for Ceilings & $\begin{array}{l}\text { Fixings for Ceilings GIB SCREWS } 6 * 30 \mathrm{MM} \\
\text { COLL'D 1000BX }\end{array}$ & $\begin{array}{l}\text { PR_20_29_ } \\
\text { 56_11 }\end{array}$ & $\begin{array}{l}\text { Carbon steel nails_Galv } \\
\text { Steel Fixing_PLACEHOLDER }\end{array}$ & 0 & 0 & 0 & $\begin{array}{l}\text { EE_25- } \\
40-10 \\
\end{array}$ & $\begin{array}{l}\text { Internal Walls } \\
\text { Structure }\end{array}$ & 0 & 0 & 0.0016956 & \\
\hline Interior Lining Bracing Sheets Auto & $\begin{array}{l}\text { Bracing Sheets Auto BRACENOISELINE } \\
2400^{*} 10 \mathrm{MM} \text { INCI NAils }\end{array}$ & $\begin{array}{ll}\text { PR_20_29- } \\
\text { PR_-11 }\end{array}$ & $\begin{array}{l}\text { Carbon steel nails_Galv } \\
\text { Steel Fixing_PLACEHOLDER }\end{array}$ & 0 & 0 & 0 & $\begin{array}{l}\text { EE_-25- } \\
40 \_10\end{array}$ & $\begin{array}{l}\text { Internal Walls } \\
\text { Structure }\end{array}$ & 0 & 0 & 0.0576 & \\
\hline Interior Doors Passage Set 1 & $\begin{array}{l}\text { Passage Set } 1 \text { SCHLAGE REGENT PASSAGE } \\
\text { S/CHROME }\end{array}$ & $\begin{array}{l}\text { PR_20_29_ } \\
\text { 56_11 }\end{array}$ & $\begin{array}{l}\text { Carbon steel nails_Galv } \\
\text { Steel Fixing_PLACEHOLDER }\end{array}$ & 0 & 0 & 0 & $\begin{array}{l}E E_{-} 25- \\
40_{-} 10 \\
\end{array}$ & $\begin{array}{l}\text { Internal Walls } \\
\text { Structure }\end{array}$ & 0 & 0 & 0.00024 & \\
\hline Interior Doors Privacy Lock 1 & $\begin{array}{l}\text { Privacy Lock } 1 \text { SCHLAGE REGENT PRIVACY } \\
\text { S/CHROME }\end{array}$ & $\begin{array}{l}\text { PR_20_29_ } \\
\text { 56_11 }\end{array}$ & $\begin{array}{l}\text { Carbon steel nails_Galv } \\
\text { Steel Fixing_PLACEHOLDER }\end{array}$ & 0 & 0 & 0 & $\begin{array}{l}\text { EE_25_ } \\
40 \_10\end{array}$ & $\begin{array}{l}\text { Internal Walls } \\
\text { Structure }\end{array}$ & 0 & 0 & 0.000096 & \\
\hline Interior Doors Dummy $1 \mathrm{LH}$ & $\begin{array}{l}\text { Dummy } 1 \text { LH SCHLAGE REGENT DUMMY } \\
\text { S/CHROME }\end{array}$ & $\begin{array}{l}\text { PR_20_29_ } \\
\text { 56_11 }\end{array}$ & $\begin{array}{l}\text { Carbon steel nails_Galv } \\
\text { Steel Fixing_PLACEHOLDER }\end{array}$ & 0 & 0 & 0 & $\begin{array}{l}\text { EE_25- } \\
40-10\end{array}$ & $\begin{array}{l}\text { Internal Walls } \\
\text { Structure }\end{array}$ & 0 & 0 & 0.000144 & \\
\hline Interior Doors Cavity Handle & $\begin{array}{l}\text { Cavity Handle CAVITY SLIDER PASSAGE } \\
\text { CI200 (D) NON-LATCHING SATIN CHR }\end{array}$ & $\begin{array}{l}\text { PR_20_29_ } \\
\text { 56_- }\end{array}$ & $\begin{array}{l}\text { Carbon steel nails_Galv } \\
\text { Steel Fixing_PLACEHOLDER }\end{array}$ & 0 & 0 & 0 & $\begin{array}{l}\text { EE_25- } \\
40-10\end{array}$ & $\begin{array}{l}\text { Internal Walls } \\
\text { Structure }\end{array}$ & 0 & 0 & 0.00002 & \\
\hline Interior Doors Door Stop Wall & Door Stop Wall DOOR STOP PVC & $\begin{array}{l}\text { PR_20_29_ } \\
\text { 56_-11 }\end{array}$ & $\begin{array}{l}\text { Carbon steel nails_Galv } \\
\text { Steel Fixing_PLACEHOLDER }\end{array}$ & 0 & 0 & 0 & $\begin{array}{l}\text { EE_25- } \\
40-10\end{array}$ & $\begin{array}{l}\text { Internal Walls } \\
\text { Structure } \\
\end{array}$ & 0 & 0 & 0.00007 & \\
\hline
\end{tabular}


Appendix 3: Test Model Schedule Sheet

\begin{tabular}{|c|c|c|c|c|c|c|c|c|c|c|c|c|}
\hline \multicolumn{13}{|c|}{ TEST MODEL } \\
\hline Category & Family & Type & $\begin{array}{l}\text { Material: } \\
\text { Description }\end{array}$ & Material: Name & $\begin{array}{l}\text { Mater } \\
\text { ial: } \\
\text { Com } \\
\text { ments }\end{array}$ & CBI Code & $\begin{array}{l}\text { CBI } \\
\text { Description }\end{array}$ & $\begin{array}{l}\text { Building } \\
\text { Element } \\
\text { Code }\end{array}$ & Building Element Description & $\begin{array}{l}\text { Material } \\
\text { : Area }\end{array}$ & $\begin{array}{l}\text { Material } \\
\text { : Volume }\end{array}$ & $\begin{array}{l}\text { Tota } \\
1 \\
\text { Prim } \\
\text { ary } \\
\text { Ener }\end{array}$ \\
\hline \multirow{13}{*}{ Sub Floor } & Column Timber (M) & $125 \times 124$ Anchor Piles & PR_20_76_88 & $\begin{array}{l}\text { Timber, soft wood, sawn kiln- } \\
\text { dried sections }\end{array}$ & 0 & 0 & 0 & EE_20_20_05 & Lowest Floors Substructure & 0 & 0.24 & \\
\hline & Column Timber (M) & $125 \times 124$ Standard Pile & PR_20_76_88 & $\begin{array}{l}\text { Timber, soft wood, sawn kiln- } \\
\text { dried sections }\end{array}$ & 0 & 0 & 0 & EE_20_20_05 & Lowest Floors Substructure & 0 & 0.33 & \\
\hline & $\begin{array}{l}\text { Timber Gauged } \\
\text { (NZ) }\end{array}$ & $140 \times 90$ Foundation Bearers & PR_20_76_88 & $\begin{array}{l}\text { Timber, soft wood, sawn kiln- } \\
\text { dried sections }\end{array}$ & 0 & 0 & 0 & EE_20_20_05 & Lowest Floors Substructure & 0 & 0.68 & \\
\hline & $\begin{array}{l}\text { Timber Gauged } \\
\text { (NZ) }\end{array}$ & $144 \times 50$ Floor Joists & PR_20_76_88 & $\begin{array}{l}\text { Timber, soft wood, sawn kiln- } \\
\text { dried sections }\end{array}$ & 0 & 0 & 0 & EE_20_20_05 & Lowest Floors Substructure & 0 & 2.075 & \\
\hline & $\begin{array}{l}\text { Timber Gauged } \\
\text { (NZ) }\end{array}$ & $144 \times 50$ Floor Boundary Joists (6.6M) & PR_20_76_88 & $\begin{array}{l}\text { Timber, soft wood, sawn kiln- } \\
\text { dried sections }\end{array}$ & 0 & 0 & 0 & EE_20_20_05 & Lowest Floors Substructure & 0 & 0.352 & \\
\hline & $\begin{array}{l}\text { Timber Gauged } \\
\text { (NZ) }\end{array}$ & $90 \times 45$ Nogging Under Interior Wall Framing & PR_20_76_88 & $\begin{array}{l}\text { Timber, soft wood, sawn kiln- } \\
\text { dried sections }\end{array}$ & 0 & 0 & 0 & EE_20_20_05 & Lowest Floors Substructure & 0 & 0.024 & \\
\hline & \begin{tabular}{|l|} 
Timber Gauged \\
(NZ)
\end{tabular} & $144 \times 50$ Solid Mid Row Floor Nogs @ 1800 centre & PR_20_76_88 & $\begin{array}{l}\text { Timber, soft wood, sawn kiln- } \\
\text { dried sections }\end{array}$ & 0 & 0 & 0 & EE_20_20_05 & Lowest Floors Substructure & 0 & 0.034 & \\
\hline & $\begin{array}{l}\text { Timber Gauged } \\
\text { (NZ) }\end{array}$ & $50 \times 100 \mathrm{~mm}$ Strongback & PR_20_76_88 & $\begin{array}{l}\text { Timber, soft wood, sawn kiln- } \\
\text { dried sections }\end{array}$ & 0 & 0 & 0 & EE_20_10_10 & Roofs Structure & 0 & 0.093 & \\
\hline & $\begin{array}{l}\text { Timber Gauged } \\
\text { (NZ) }\end{array}$ & $100 \times 25 \mathrm{~mm}$ Baseboards & PR_20_76_88 & $\begin{array}{l}\text { Timber, soft wood, sawn kiln- } \\
\text { dried sections }\end{array}$ & 0 & 0 & 0 & EE_20_20_05 & Lowest Floors Substructure & 0 & 0.832 & \\
\hline & Floor & STRANDBOARD $3.60 * 2.40 * 20 \mathrm{~mm}$ UF RESIN & PR_20_76_88 & $\begin{array}{l}\text { Timber, soft wood, sawn kiln- } \\
\text { dried sections }\end{array}$ & 0 & 0 & 0 & EE_20_20_20 & Lowest Floors Flooring & 0 & 2.35 & \\
\hline & Floor & $\begin{array}{l}\text { Footing Sizes DN (Anchor (Case) 400×400×900), MIN 17.5MPa } \\
\text { Concrete Strength @ } 28 \text { Days }\end{array}$ & $\begin{array}{l}\text { PR_20_31_16_1 } \\
\text { ___1_1 }\end{array}$ & $\begin{array}{l}\text { Concrete, } 17.5 \mathrm{MPa} \text {, in-situ, no } \\
\text { reinforcement, (OPC) }\end{array}$ & 0 & 0 & 0 & EE_20_20_05 & Lowest Floors Substructure & 0 & 1.27 & \\
\hline & Floor & $\begin{array}{l}\text { Footing Sizes DN (Ordinary (Case) 450x400x100mm), MIN 17.5MPa } \\
\text { Concrete Strength @ } 28 \text { Days }\end{array}$ & $\begin{array}{l}\text { PR_20_31_16_1 } \\
\text { ___1_1 }\end{array}$ & $\begin{array}{l}\text { Concrete, } 17.5 \mathrm{MPa} \text {, in-situ, no } \\
\text { reinforcement, (OPC) }\end{array}$ & 0 & 0 & 0 & EE_20_20_05 & Lowest Floors Substructure & 0 & 1.11 & \\
\hline & Floor & Pile Footing (Custom Base) 400×400×100 & $\begin{array}{l}\text { PR_20_31_16_1 } \\
\text { _1_1_1 }\end{array}$ & $\begin{array}{l}\text { Concrete, } 17.5 \mathrm{MPa} \text {, in-situ, no } \\
\text { reinforcement, (OPC) }\end{array}$ & 0 & 0 & 0 & EE_20_20_05 & Lowest Floors Substructure & 0 & 0.54 & \\
\hline \multirow{2}{*}{$\begin{array}{l}\text { Ceiling } \\
\text { Framing }\end{array}$} & $\begin{array}{l}\text { Timber Gauged } \\
\text { (NZ) }\end{array}$ & 70 × 35 NST Batten Ceiling KD CF & PR_20_76_88 & $\begin{array}{l}\text { Timber, soft wood, sawn kiln- } \\
\text { dried sections }\end{array}$ & 0 & 0 & 0 & EE_20_10_10 & Roofs Structure & 0 & 0.654 & \\
\hline & $\begin{array}{l}\text { Gypsum } \\
\text { Plasterboard } \\
\text { Ceiling }\end{array}$ & Compound Ceiling & $\begin{array}{l}\text { PR_25_71_52_3 } \\
7\end{array}$ & Gypsum plasterboard & 0 & 0 & 0 & EE_20_10_10 & Roofs Structure & 0 & 1.12 & \\
\hline
\end{tabular}

\begin{tabular}{|c|c|c|c|c|c|c|c|c|c|c|c|}
\hline \multirow{5}{*}{$\begin{array}{l}\text { Roof } \\
\text { Framing }\end{array}$} & Timber Gauged (NZ) & $45 \times 90 \mathrm{~mm}$ Purlins & PR_20_76_88 & Timber, soft wood, sawn kiln-dried sections & 0 & 0 & 0 & $\begin{array}{l}\text { EE_20_10_ } \\
10\end{array}$ & Roofs Structure & 0 & 0.924 \\
\hline & Timber Gauged (NZ) & $\begin{array}{l}90 \times 35 \text { Roof Framing Fly Rafters } \\
\text { MSG8 H1.2 KD Gauged }\end{array}$ & PR_20_76_88 & Timber, soft wood, sawn kiln-dried sections & 0 & 0 & 0 & $\begin{array}{l}\text { EE_20_10_ } \\
10\end{array}$ & Roofs Structure & 0 & 1.322 \\
\hline & Timber Gauged (NZ) & $\begin{array}{l}70 \times 35 \text { Soffit Ribbon Plate Roof } \\
\text { Framing H1.2 Timber }\end{array}$ & PR_20_76_88 & Timber, soft wood, sawn kiln-dried sections & 0 & 0 & 0 & $\begin{array}{l}\mathrm{EE}_{2} 20 \_10_{-} \\
10\end{array}$ & Roofs Structure & 0 & 0.169 \\
\hline & $\begin{array}{l}70 \times 35 \text { H1.2 Soffit Ribbon } \\
\text { Plate }\end{array}$ & $70 \times 35$ H1.2 Soffit Ribbon Plate & PR_20_76_88 & Timber, soft wood, sawn kiln-dried sections & 0 & 0 & 0 & $\begin{array}{l}\mathrm{EE}_{2} 20_{-} 10_{-} \\
10\end{array}$ & Roofs Structure & 0 & 0.02 \\
\hline & $\begin{array}{l}70 \times 35 \text { H1.2 Soffit Ribbon } \\
\text { Plate1 }\end{array}$ & $70 \times 35$ H1.2 Soffit Ribbon Plate & PR_20_76_88 & Timber, soft wood, sawn kiln-dried sections & 0 & 0 & 0 & $\begin{array}{l}\text { EE_20_10_ } \\
10\end{array}$ & Roofs Structure & 0 & 0.02 \\
\hline
\end{tabular}

\begin{tabular}{|c|c|c|c|c|c|c|c|c|c|c|c|c|}
\hline \multirow{2}{*}{$\begin{array}{l}\text { Soffit - } \\
\text { Fascia }\end{array}$} & $70 \times 35$ H1.2 Soffit Framing 1 & $70 \times 35$ H1.2 Soffit Framing & PR_20_76_88 & Timber, soft wood, sawn kiln-dried sections & 0 & 0 & & 0 & $\begin{array}{l}\text { EE_20_10_ } \\
10\end{array}$ & Roofs Structure & 0 & 0.01 \\
\hline & Timber Gauged (NZ) & $181 \times 19 \mathrm{~mm}$ (Reviti ${ }^{\mathrm{TM}}$ Custom) Fascia & PR_20_76_88 & Timber, soft wood, sawn kiln-dried sections & & 0 & & & $\begin{array}{l}\text { EE_20_10_ } \\
40\end{array}$ & \begin{tabular}{|l|} 
Roofs External \\
Coverings
\end{tabular} & 0 & 0.131 \\
\hline
\end{tabular}

75|P a g e 


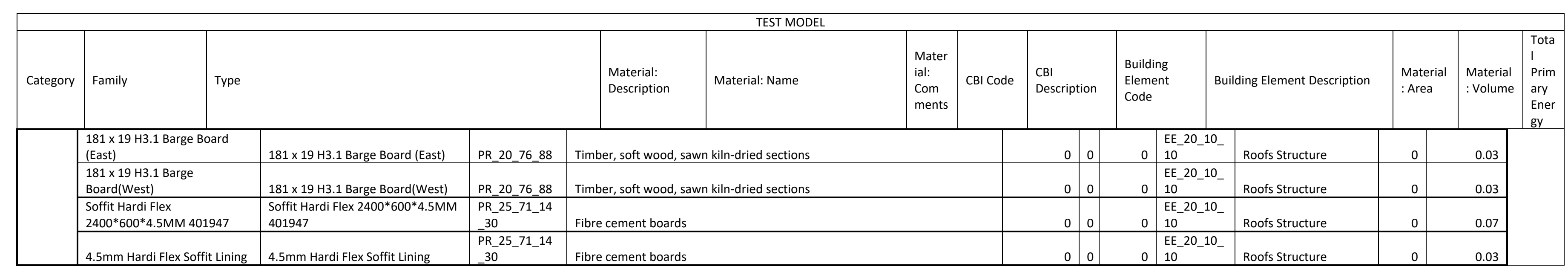

\begin{tabular}{|c|c|c|c|c|c|c|c|c|c|c|c|}
\hline $\begin{array}{c}\text { Roof } \\
\text { Materia } \\
\quad \\
\end{array}$ & Basic Roof & $\begin{array}{l}\text { Trapazoidal } 27 \mathrm{~mm} \text { Profile } \\
\text { Unpainted Zinalume Roof }\end{array}$ & $\begin{array}{l}\text { PR_25_71_51 } \\
\text { 89_1_3_1 } \\
\end{array}$ & $\begin{array}{l}\text { Steel }(150 \mathrm{~g} / \mathrm{m} 2 \text { zinc/aluminium alloy finish both sides), profile metal sheet, } \\
\text { generic all profiles, } 0.4 \mathrm{~mm} \text { BMT }\end{array}$ & $\mathrm{m} 3 / \mathrm{m} 2$ & 0 & 0 & $\begin{array}{l}\text { EE_20_10_ } \\
10\end{array}$ & Roofs Structure & 0 & 4.26 \\
\hline \multirow{7}{*}{$\begin{array}{c}\text { Alumin } \\
\text { um } \\
\text { Framing } \\
\text { Materia } \\
\text { Is } \\
\text { (Total) }\end{array}$} & $\begin{array}{l}\text { Wooden- } \\
\text { AlumFrame_Door_Ext_lnt }\end{array}$ & $850 \times 2032 \mathrm{~mm}$ (Aluminium_Ext) & $\begin{array}{l}\text { PR_20_76_51 } \\
\text { 2__1 }\end{array}$ & $\begin{array}{l}\text { Aluminium (powder coated finish, one side } 0.08 \mathrm{~mm} \text { ), extruded glazing } \\
\text { frame, } 2.0 \mathrm{~mm} \text { BMT }\end{array}$ & 0 & 0 & 0 & $\begin{array}{l}\text { EE_25_25_ } \\
10\end{array}$ & $\begin{array}{l}\text { External Single Skin } \\
\text { Walls Structure }\end{array}$ & 0 & 0.02 \\
\hline & Aluminium Sliding Door_Ext & $2450 \times 2100 \mathrm{~mm}$ & $\begin{array}{l}\text { PR_20_76_51 } \\
\text { 2__1 }\end{array}$ & $\begin{array}{l}\text { Aluminium (powder coated finish, one side } 0.08 \mathrm{~mm} \text { ), extruded glazing } \\
\text { frame, } 2.0 \mathrm{~mm} \text { BMT }\end{array}$ & 0 & 0 & 0 & $\begin{array}{ll}\text { EE_25_25_ } \\
10\end{array}$ & $\begin{array}{l}\text { External Single Skin } \\
\text { Walls Structure }\end{array}$ & 0 & 0.13 \\
\hline & $\begin{array}{l}\text { Window Mullion\&Transom } \\
\text { Template }\end{array}$ & $600 \times 1000$ (G6) & $\begin{array}{l}\text { PR_20_76_51 } \\
\text { 2__1 }\end{array}$ & $\begin{array}{l}\text { Aluminium (powder coated finish, one side } 0.08 \mathrm{~mm} \text { ), extruded glazing } \\
\text { frame, } 2.0 \mathrm{~mm} \text { BMT }\end{array}$ & 0 & 0 & 0 & $\begin{array}{ll}\mathrm{EE}_{2} 25 \_25 \\
10\end{array}$ & $\begin{array}{l}\text { External Single Skin } \\
\text { Walls Structure }\end{array}$ & 0 & 0.042 \\
\hline & $\begin{array}{l}\text { Window Mullion\&Transom } \\
\text { Template }\end{array}$ & $1200 \times 1000$ & $\begin{array}{l}\text { PR_20_76_51 } \\
\text { 2__1 }\end{array}$ & $\begin{array}{l}\text { Aluminium (powder coated finish, one side } 0.08 \mathrm{~mm} \text { ), extruded glazing } \\
\text { frame, } 2.0 \mathrm{~mm} \text { BMT }\end{array}$ & 0 & 0 & 0 & $\begin{array}{ll}\mathrm{EE}-25 \_25 \\
10\end{array}$ & $\begin{array}{l}\text { External Single Skin } \\
\text { Walls Structure }\end{array}$ & 0 & 0.015 \\
\hline & $\begin{array}{l}\text { Window Mullion\&Transom } \\
\text { Template }\end{array}$ & $1490 \times 1200$ & $\begin{array}{l}\text { PR_20_76_51 } \\
\text { 2__1 }\end{array}$ & $\begin{array}{l}\text { Aluminium (powder coated finish, one side } 0.08 \mathrm{~mm} \text { ), extruded glazing } \\
\text { frame, } 2.0 \mathrm{~mm} \text { BMT }\end{array}$ & 0 & 0 & 0 & $\begin{array}{ll}\mathrm{EE}_{2} 25 \_25 \\
10\end{array}$ & $\begin{array}{l}\text { External Single Skin } \\
\text { Walls Structure }\end{array}$ & 0 & 0.024 \\
\hline & $\begin{array}{l}\text { Window Mullion\&Transom } \\
\text { Template }\end{array}$ & $1700 \times 500$ & 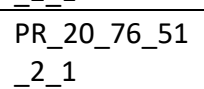 & $\begin{array}{l}\text { Aluminium (powder coated finish, one side } 0.08 \mathrm{~mm} \text { ), extruded glazing } \\
\text { frame, } 2.0 \mathrm{~mm} \text { BMT }\end{array}$ & 0 & 0 & 0 & $\begin{array}{l}\mathrm{EE}-25 \_25 \\
10\end{array}$ & $\begin{array}{l}\text { External Single Skin } \\
\text { Walls Structure }\end{array}$ & 0 & 0.02 \\
\hline & $\begin{array}{l}\text { Window Mullion\&Transom } \\
\text { Template }\end{array}$ & $1700 \times 1100(J 16)$ & PR_20_76_51 & $\begin{array}{l}\text { Aluminium (powder coated finish, one side } 0.08 \mathrm{~mm} \text { ), extruded glazing } \\
\text { frame, } 2.0 \mathrm{~mm} \text { BMT }\end{array}$ & 0 & 0 & 0 & $\begin{array}{ll}\mathrm{EE}-25 \_25 \\
10\end{array}$ & $\begin{array}{l}\text { External Single Skin } \\
\text { Walls Structure }\end{array}$ & 0 & 0.051 \\
\hline
\end{tabular}

\begin{tabular}{|c|c|c|c|c|c|c|c|c|c|c|}
\hline \multirow{7}{*}{$\begin{array}{l}\text { Window and Door } \\
\text { (Glass Material) }\end{array}$} & $\begin{array}{l}\text { Wooden- } \\
\text { AlumFrame_Door_Ext_Int }\end{array}$ & $850 \times 2032 \mathrm{~mm}$ (Aluminium_Ext) & PR_25_71_33_37 & Glass, heat strengthened & 0 & 0 & \begin{tabular}{l|l} 
& EE_25_25_ \\
0 & 10
\end{tabular} & $\begin{array}{l}\text { External Single Skin } \\
\text { Walls Structure }\end{array}$ & 0 & 0.09 \\
\hline & Aluminium Sliding Door_Ext & $2450 \times 2100 \mathrm{~mm}$ & PR_25_71_33_37 & Glass, heat strengthened & 0 & 0 & \begin{tabular}{l|l} 
& EE_25_25_ \\
0 & 10 \\
\end{tabular} & $\begin{array}{l}\text { External Single Skin } \\
\text { Walls Structure }\end{array}$ & 0 & 0.25 \\
\hline & $\begin{array}{l}\text { Window Mullion\&Transom } \\
\text { Template }\end{array}$ & $600 \times 1000$ (G6) & PR_25_71_33_37 & Glass, heat strengthened & 0 & & \begin{tabular}{l|l} 
& EE_25_25_ \\
0 & 10
\end{tabular} & $\begin{array}{l}\text { External Single Skin } \\
\text { Walls Structure }\end{array}$ & 0 & 0.012 \\
\hline & $\begin{array}{l}\text { Window Mullion\&Transom } \\
\text { Template }\end{array}$ & $1200 \times 1000$ & PR_25_71_33_37 & Glass, heat strengthened & 0 & & \begin{tabular}{l|l} 
& EE_25_25_ \\
0 & 10 \\
\end{tabular} & $\begin{array}{l}\text { External Single Skin } \\
\text { Walls Structure }\end{array}$ & 0 & 0.005 \\
\hline & $\begin{array}{l}\text { Window Mullion\&Transom } \\
\text { Template }\end{array}$ & $1490 \times 1200$ & PR_25_71_33_37 & Glass, heat strengthened & 0 & & \begin{tabular}{l|l} 
& EE_25_25_ \\
0 & 10
\end{tabular} & $\begin{array}{l}\text { External Single Skin } \\
\text { Walls Structure }\end{array}$ & 0 & 0.018 \\
\hline & $\begin{array}{l}\text { Window Mullion\&Transom } \\
\text { Template }\end{array}$ & $1700 \times 500$ & PR_25_71_33_37 & Glass, heat strengthened & 0 & & \begin{tabular}{l|l} 
& EE_25_25_ \\
0 & 10
\end{tabular} & $\begin{array}{l}\text { External Single Skin } \\
\text { Walls Structure }\end{array}$ & 0 & 0.006 \\
\hline & $\begin{array}{l}\text { Window Mullion\&Transom } \\
\text { Template }\end{array}$ & $1700 \times 1100(J 16)$ & PR_25_71_33_37 & Glass, heat strengthened & 0 & & \begin{tabular}{l|l} 
& EE_25_25_ \\
10
\end{tabular} & $\begin{array}{l}\text { External Single Skin } \\
\text { Walls Structure }\end{array}$ & 0 & 0.031 \\
\hline
\end{tabular}

\begin{tabular}{|c|c|c|c|c|c|c|c|c|c|c|c|}
\hline \multirow{4}{*}{ Exterior Wall Timber } & Basic Wall & $\begin{array}{l}\text { Bevel bak Weatherboard, } 90 \mathrm{~mm} \text { frame, Insulation } \\
\text { Membrane, polyethylene (PE) }\end{array}$ & PR_20_76_88 & $\begin{array}{l}\text { Timber, soft wood, sawn kiln-dried } \\
\text { sections }\end{array}$ & 0 & 0 & 0 & $\begin{array}{l}\text { EE_25_25_ } \\
10\end{array}$ & $\begin{array}{l}\text { External Single Skin } \\
\text { Walls Structure }\end{array}$ & 0 & 1.122 \\
\hline & Basic Wall & $\begin{array}{l}\text { Bevel bak Weatherboard, 90mm frame, Insulation } \\
\text { Membrane, polyethylene (PE) }\end{array}$ & PR_25_71_52_37 & Gypsum plasterboard & 0 & 0 & 0 & $\begin{array}{l}\text { EE_25_25_ } \\
10\end{array}$ & $\begin{array}{l}\text { External Single Skin } \\
\text { Walls Structure }\end{array}$ & 0 & 0.916 \\
\hline & Basic Wall & Roof Gable Wall & PR_25_71_52_37 & Gypsum plasterboard & 0 & 0 & 0 & $\begin{array}{l}\text { EE_25_25_ } \\
10\end{array}$ & $\begin{array}{l}\text { External Single Skin } \\
\text { Walls Structure }\end{array}$ & 0 & 0.362 \\
\hline & Basic Wall & Interior Timber Frame Wall & PR_20_76_88 & $\begin{array}{l}\text { Timber, soft wood, sawn kiln-dried } \\
\text { sections }\end{array}$ & 0 & 0 & 0 & EE_25_40 & Internal Walls & 0 & 1.318 \\
\hline
\end{tabular}

76|P a g e 


\begin{tabular}{|c|c|c|c|c|c|c|c|c|c|c|c|c|}
\hline \multicolumn{13}{|c|}{ TEST MODEL } \\
\hline Category & Family & Type & $\begin{array}{l}\text { Material: } \\
\text { Description }\end{array}$ & Material: Name & $\begin{array}{l}\text { Mater } \\
\text { ial: } \\
\text { com } \\
\text { ments }\end{array}$ & CBI Code & $\begin{array}{l}\text { CBI } \\
\text { Description }\end{array}$ & $\begin{array}{l}\text { Building } \\
\text { Element } \\
\text { Code }\end{array}$ & Building Element Description & $\begin{array}{l}\text { Material } \\
\text { : Area }\end{array}$ & $\begin{array}{l}\text { Material } \\
\text { :Volume }\end{array}$ & $\begin{array}{l}\text { Tota } \\
1 \\
\text { Prim } \\
\text { ary } \\
\text { Ener }\end{array}$ \\
\hline
\end{tabular}

\begin{tabular}{|c|c|c|c|c|c|c|c|c|c|c|c|}
\hline \multirow{3}{*}{ Insulation } & Basic Wall & $\begin{array}{l}\text { Bevel bak Weatherboard, } 90 \mathrm{~mm} \text { frame, Insulation } \\
\text { Membrane, polyethylene (PE) }\end{array}$ & PR_25_57_6_30 & Insulation, Glass Wool & 0 & 0 & 0 & $\begin{array}{ll}\mathrm{EE} 25 \_25 \\
10\end{array}$ & $\begin{array}{l}\text { External Single Skin } \\
\text { Walls Structure }\end{array}$ & 0 & 6.991 \\
\hline & Insulation & Insulation & PR_25_57_6_30 & Insulation, Glass Wool & 0 & 0 & 0 & $\begin{array}{l}\text { EE_20_10_ } \\
10\end{array}$ & Roofs Structure & 0 & 9.76 \\
\hline & Insulation - Koolfoam & Insulation - Koolfoam & PR_25_71_13_2 & $\begin{array}{l}\text { Insulation, polystyrene expanded } \\
\text { (EPS) }\end{array}$ & 0 & 0 & 0 & $\begin{array}{l}\mathrm{EE}{ }_{2} 20 \_20 \\
05\end{array}$ & $\begin{array}{l}\text { Lowest Floors } \\
\text { Substructure }\end{array}$ & 0 & 5.00 \\
\hline
\end{tabular}

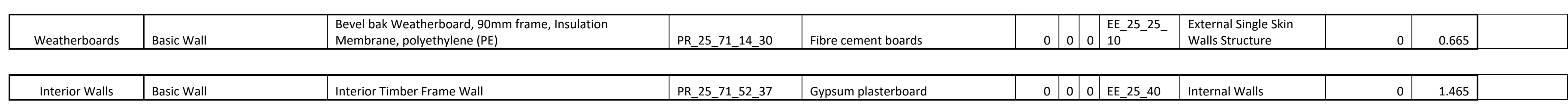

\begin{tabular}{|c|c|c|c|c|c|c|c|c|c|c|c|}
\hline \multirow{5}{*}{ Doors } & $\begin{array}{l}\text { Int Cavity Slider-Single- } \\
\text { Flush (NZ) }\end{array}$ & $760 \times 1980 \mathrm{~mm}$ & PR_20_76_88 & $\begin{array}{l}\text { Timber, soft wood, sawn kiln-dried } \\
\text { sections }\end{array}$ & 0 & 0 & 0 & EE_25_40_30 & Internal Walls Accessible Openings & 0 & 0.07 \\
\hline & M_Single-Flush & $510 \times 2030 \mathrm{~mm}$ & PR_20_76_88 & $\begin{array}{l}\text { Timber, soft wood, sawn kiln-dried } \\
\text { sections }\end{array}$ & 0 & 0 & 0 & EE_25_40_30 & Internal Walls Accessible Openings & 0 & 0.07 \\
\hline & M_Single-Flush & $610 \times 2032 \mathrm{~mm}$ & PR_20_76_88 & $\begin{array}{l}\text { Timber, soft wood, sawn kiln-dried } \\
\text { sections }\end{array}$ & 0 & 0 & 0 & EE_25_40_30 & Internal Walls Accessible Openings & 0 & 0.16 \\
\hline & Int Double-Flush (NZ) & $1220 \times 1980 \mathrm{~mm}$ & PR_20_76_88 & $\begin{array}{l}\text { Timber, soft wood, sawn kiln-dried } \\
\text { sections }\end{array}$ & 0 & 0 & 0 & EE_25_40_30 & Internal Walls Accessible Openings & 0 & 0.13 \\
\hline & M_Single-Flush & $760 \times 2032 \mathrm{~mm}$ & PR_20_76_88 & $\begin{array}{l}\text { Timber, soft wood, sawn kiln-dried } \\
\text { sections }\end{array}$ & & 0 & 0 & EE_25_40_30 & Internal Walls Accessible Openings & 0 & 0.59 \\
\hline
\end{tabular}



Appendix 4: The Unmatched Results of the Test Model

\begin{tabular}{|c|c|c|c|c|c|c|c|c|c|c|c|}
\hline \multicolumn{12}{|c|}{ UNMATCHED MATERIALS } \\
\hline Void & $\begin{array}{l}\text { Basic } \\
\text { Wall }\end{array}$ & Interior Timber Frame Wall & Air & Air & 0 & 0 & 0 & EE_25_40 & Internal Walls & 0 & 5.274 \\
\hline $\begin{array}{l}\text { Roof Membrane/ building } \\
\text { paper }\end{array}$ & $\begin{array}{l}\text { Basic } \\
\text { Roof }\end{array}$ & Trapazoidal 27mm Profile Unpainted Zinalume Roof & $\begin{array}{l}\text { PR_15_57_30_4 } \\
\text { 7_1 }\end{array}$ & $\begin{array}{l}\text { Membrane, } \\
\text { polyethylene (PE) }\end{array}$ & 0 & 0 & 0 & $\begin{array}{l}\text { EE_20_10_ } \\
10\end{array}$ & Roofs Structure & 0 & 0.79 \\
\hline $\begin{array}{l}\text { Wall membrane/ building } \\
\text { paper }\end{array}$ & $\begin{array}{l}\text { Basic } \\
\text { Wall }\end{array}$ & $\begin{array}{l}\text { Bevel bak Weatherboard, 90mm frame, Insulation Membrane, } \\
\text { polyethylene (PE) }\end{array}$ & $\begin{array}{l}\text { PR_15_57_30_4 } \\
\text { 7_1 }\end{array}$ & $\begin{array}{l}\text { Membrane, } \\
\text { polyethylene (PE) }\end{array}$ & 0 & 0 & 0 & $\begin{array}{l}\text { EE_25_25_ } \\
10\end{array}$ & $\begin{array}{l}\text { External Single Skin } \\
\text { Walls Structure }\end{array}$ & 0 & 0.444 \\
\hline
\end{tabular}

